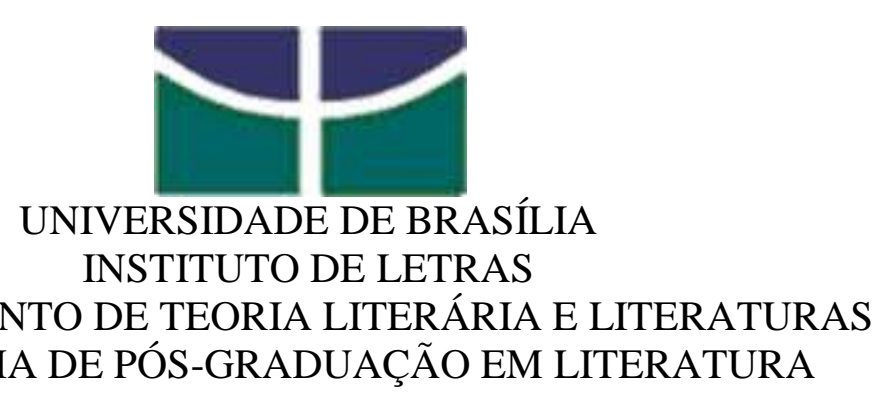

KELLY FABÍOLA VIANA DOS SANTOS

RECURSOS ESTÉTICOS E ALTERIDADE: UMA LEITURA INTERARTES DO CONTO A TERCEIRA MARGEM DO RIO, DE JOÃO GUIMARÃES ROSA

BRASÍLIA - DF

2014 
KELLY FABÍOLA VIANA DOS SANTOS

RECURSOS ESTÉTICOS E ALTERIDADE: UMA LEITURA INTERARTES DO CONTO A TERCEIRA MARGEM DO RIO, DE JOÃO GUIMARÃES ROSA

Dissertação apresentada ao Programa de PósGraduação em Literatura do Departamento de Teoria Literária e Literaturas - TEL do Instituto de Letras da Universidade de Brasília - UnB como requisito parcial para a obtenção do título de Mestre.

Área de concentração: Literatura

Linha de Pesquisa: Literatura e outras Artes

Orientador: Prof. Dr. Robson Coelho Tinoco

BRASÍLIA - DF

2014 


\section{RECURSOS ESTÉTICOS E ALTERIDADE: UMA LEITURA INTERARTES DO CONTO A TERCEIRA MARGEM DO RIO, DE JOÃO GUIMARÃES ROSA}

Dissertação defendida no Programa de Pós-Graduação do Departamento de Teoria Literária e Literaturas do Instituto de Letras da Universidade de Brasília, para a obtenção do grau de mestre, aprovada em 10 de dezembro de 2014, pela Banca Examinadora constituída pelos seguintes professores:

Prof. Dr. Robson Coelho Tinoco - TEL/UnB

Orientador e Presidente da Banca

Prof. ${ }^{\text {a }}$ Dr. ${ }^{\text {a }}$ Sylvia Helena Cyntrão (TEL-UnB)

Membro interno

Prof. $^{\text {a }}$ Dr. ${ }^{a}$ Patrícia Lima Martins Pederiva (FE-UnB)

Membro externo

Prof. Dr. André Luís Gomes (TEL-UnB)

Suplente 
Aos alunos, professores e amigos do Centro de Ensino Fundamental 120 de Samambaia Sul, que presenciaram a primeira inspiração dessa obra, a exposição Mensagem a um general, em julho de 2012.

Aos estudantes que, no passado, no presente e no futuro, fizeram, fazem ou farão parte da minha história de vida pessoal e acadêmica.

A todos os pesquisadores em arte e literatura que conseguem enxergar nessas produções o olhar do Outro. 


\section{AGRADECIMENTOS}

Ao Prof. Dr. Robson Coelho Tinoco, que primeiro acreditou e depositou suas esperanças na concretização desse trabalho, quando ainda era apenas um projeto vacilante, embora pleno de entusiasmo pelo estudo da arte, da leitura e da educação.

Aos professores de disciplinas, às quais cheguei aluna e saí radiantemente iluminada pelo acolhimento e sabedoria: Anderson da Mata, Claudia Falluh Balduíno, Piero Eyben, Regina Dalcastagnè, Robson Coelho Tinoco e Sylvia Cyntrão.

Aos professores e professoras, dos quais não cheguei a cursar disciplina, mas que muito me auxiliaram em conversas, palestras, reuniões e eventos do programa de pós-graduação em literatura da UnB.

Aos amigos e amigas, estudantes da pós-graduação, que compartilharam comigo as expectativas, as alegrias, as reflexões e divagações; as angústias, as frustrações e, por que não?, o desespero que todo trabalho acadêmico provoca.

A Deus e à Santa Ana, padroeira dos estudantes, que me infundiram a fé, a esperança, a sabedoria e a luz nos momentos em que nenhum outro auxílio me foi capaz de iluminar. 
"O escritor a que se chama clássico - pelo menos na Françasacrifica em si a fala que lhe é própria, mas para dar voz ao universal".

O Espaço literário, Maurice Blanchot 


\section{RESUMO}

Este trabalho busca verificar nas apropriações, intertextos e interdiscursos das artes contemporâneas, como os recursos estéticos verbais e não verbais enriquecem as produções e ampliam a forma de se comunicar sentidos e alteridades. Na análise dos intertextos e das transposições de obras de linguagem verbal em obras de linguagem não verbal, pretende-se verificar como se realizam as acomodações aos recursos estéticos próprios de cada linguagem, sem se desfazer os vínculos com a obra original. O conto A terceira margem do rio, de João Guimarães Rosa, por ter influenciado a produção de diversas outras obras, é o ponto de partida deste estudo interartes. As diferentes expressões de alteridade na literatura e nas artes visuais, bem como os limites da linguagem visual em confronto com os limites da linguagem escrita para expressar sentidos e significados, são analisados a partir da transposição do conto de Guimarães Rosa para a canção de Caetano Veloso e, desta, para a instalação artística de Guto Lacaz. As três obras são homônimas, o que denuncia de imediato a ocorrência do intertexto. As questões de alteridade suscitadas pelas obras são averiguadas à luz dos estudos dos filósofos Emmanuel Levinas, Paul Ricoeur e Jacques Derrida. Ao final, por meio da análise de um caso concreto, este estudo pretende demonstrar como as transposições de linguagens artísticas podem ser incentivadas no ambiente escolar, a fim de proporcionar expressão artística e literária aos estudantes, partindo-se da leitura e interpretação de poemas.

Palavras-chave: arte contemporânea. interartes. interdiscurso. Caetano Veloso. Guto Lacaz. João Guimarães Rosa. 


\begin{abstract}
This work aims to verify, in the appropriations, intertexts and interdiscourses of contemporary arts, such as verbal and nonverbal resources can enrich the aesthetic productions as well as it expands the ways to communicate senses and otherness. In the analysis of intertexts and of the artistic transpositions from works of verbal language into works of non-verbal language, we intend to investigate how the accommodations into the own aesthetic resources of each language, without undoing the ties to the original work, is performed. The tale A terceira margem do rio, by Guimarães Rosa, for having influenced the production of several other works, is the starting point of this interart study. The different expressions of otherness in Literature and in the Visual Arts, as well as the limits of the visual language in confrontation with the limits of writing to express meanings and significances, are analyzed from the transposition of the story by Guimarães Rosa for the song by Caetano Veloso and then, for the art installation by Guto Lacaz. The three works are homonyms, which immediately denounces the occurrence of the intertext. The issues of otherness raised by those works of art will be investigated in the light of the studies of philosophers Emmanuel Levinas, Paul Ricoeur and Jacques Derrida. Finally, through the analysis of a particular case, this study aims to demonstrate how the transpositions of artistic languages can be encouraged in the school environment in order to provide students with artistic and literary expression, starting from the reading and interpretation of poems.
\end{abstract}

Keywords: contemporary art. interarts. interdiscourse. Caetano Veloso. Guto Lacaz. João Guimarães Rosa. 


\section{LISTA DE ILUSTRAÇÕES}

Figura 1 - Maquete A terceira margem do rio: obra de Guto Lacaz, para o projeto A imagem do som de Caetano Veloso organizado por Felipe Taborda (1998) ....................................... 14

Figura 2 - Instalação artística A terceira margem do rio, de Guto Lacaz, que foi exposta na marquise do Parque Ibirapuera, São Paulo (março 2010) ..................................................... 15

Figura 3 - Escultura Davi do artista renascentista Michelangelo ......................................... 38

Figura 4 - Participação do público à exposição no Parque Ibirapuera (2010) ......................... 39

Figura 5 - Quadro A tempestade, de Giorgione (1477-1510).............................................. 79

Figura 6 - Escultura Laocoonte e seus filhos....................................................................... 95

Figura 7 - Instalação artística Mensagem a um general, de Kelly Vyanna ........................... 105 


\section{SUMÁRIO}

Introdução

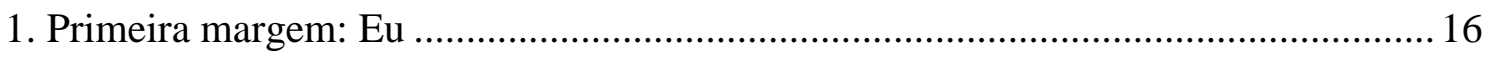

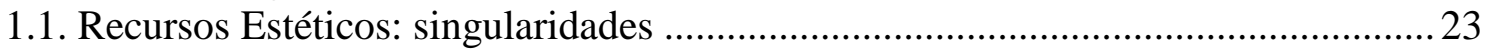

1.2. Prosa, poema e letra poética: diferenças e semelhanças ............................................. 40

1.3. Definiçõos e considerações sobre instalação artística ................................................ 42

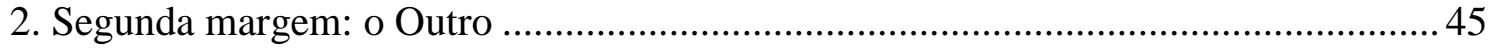

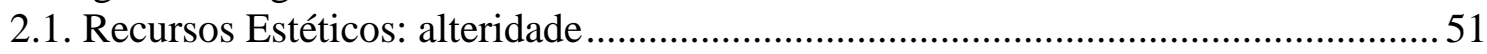

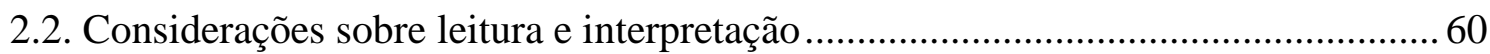

2.3. Intertextos e interdiscursos: estilização, paródia, paráfrase ........................................ 66

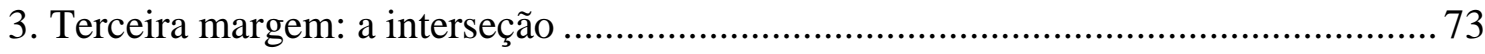

3.1. Recursos Estéticos: mímesis, mito e representação efeito ........................................ 76

3.2. Conexões produtivas entre literatura e artes visuais ................................................ 93

3.3. Instalação artística Mensagem a um general ........................................................ 99

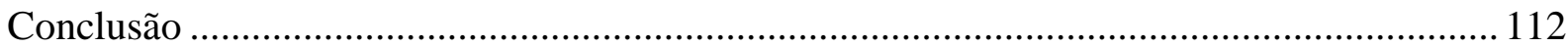

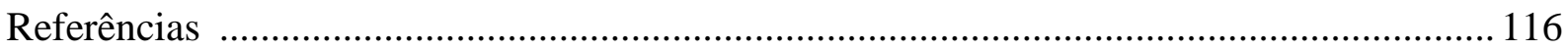

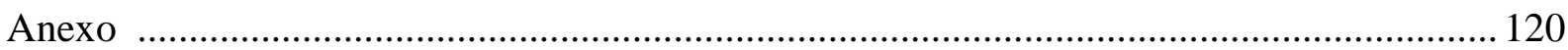




\title{
INTRODUÇÃO
}

Muitos relatos associam o ato de leitura e escrita ao ingresso em um espaço paralelo e transcendental. Michèle Petit no livro A arte de ler (2009), transcreve relatos de pessoas que passaram por experiências traumáticas e fizeram da leitura uma forma de resistência, desvio ou superação das situações e traumas por que tiveram de passar. Não apenas em situações traumáticas, mas em muitas outras situações, a leitura se relaciona a essa sensação de abertura a outro espaço. O relato a seguir já deve ter sido experimentado por muitas pessoas que leem durante o percurso em transportes públicos ou em viagens:

\begin{abstract}
Sempre leio no metrô que eu pego todos os dias para ir trabalhar. Dessa forma eu sou transportada radicalmente para outro lugar. Eu me lembro de um dia que lia uma aventura que se passava no polo Norte. Eu avançava através da nevasca, em meio às renas e aos cachorros, estava tão dentro da história que, de repente, levantei a cabeça e vi todas aquelas pessoas ao meu redor... por um momento, pensei: "Mas o que elas estão fazendo aqui?!". (ibidem, p. 80).
\end{abstract}

O marco inicial dessa pesquisa foi a leitura de um poema. De modo geral, os projetos de incentivo à leitura costumam associar essa prática à entrada em outro mundo e explanam sobre o poder de transformação que o conhecimento exerce na vida daqueles que fazem da leitura um hábito. De fato, a leitura do poema Palavras a um general, de Bertolt Brecht, operou transformações intensas na vida desta pesquisadora. As inquietações e reflexões que essa leitura provocou precisavam ser compartilhadas, divulgadas, difundidas. Desse sentimento, surgiu o desejo de transmitir, de forma singular, as impressões pessoais obtidas daquela leitura.

A instalação artística Mensagem a um general foi elaborada no intuito de compartilhar as ideias, impressões e sentimentos que o poema de Brecht suscitou nesta pesquisadora. $\mathrm{O}$ desejo de comunicar aos outros essas percepções se concretizou pela exposição da instalação no Centro de Ensino Fundamental 120 de Samambaia-DF. E continuou nas atividades relacionadas à exposição com alunos e professores da escola. Em sequência, surgiu a curiosidade quanto aos processos de transposição de ideias expostas em linguagem verbal para linguagem não verbal. Assim teve início esta pesquisa que, em seu desenvolvimento investigativo, empreendeu questões sobre recursos estéticos em literatura e outras artes, alteridade, leitura, interpretação de textos e escrita.

No que se refere à leitura e escrita, considere-se que a escrita, antes de haver transcrição do pensamento ao código verbal que lhe dará suporte, é já uma atividade leitora. Dessa forma, a escrita pode ser considerada uma atividade leitora que busca e seleciona dados 
do imaginário do autor, transformando-os, em seguida, em código verbal que se ofertará a todos quantos souberem decodificar e interpretar esse código. Desse modo, leitura e escrita são propiciadoras de abertura de espaços. Autor e leitor, embora se posicionem em diferentes perspectivas, experimentam essa ruptura que ocorre entre o Eu e o Outro, nas atividades de leitura e escrita. O espaço ocupado pelo Outro, de alguma forma e por alguns momentos, torna-se intercambiável.

O Outro, quando escrito neste estudo com $O$ maiúsculo, se refere a algo ou alguém que guarda muitas diferenças em relação ao Eu, ou seja, tudo o que se encontra fora do ego e não pode ser definido a partir das considerações racionais do sujeito (Eu). Existe entre o ego e o alter, em outras palavras, entre o Eu e o Outro, uma grande distância, uma separação, que será associada aqui às margens de um rio. Uma das questões de que trata esta pesquisa é justamente de como artes e literatura poderiam favorecer a abertura a um espaço neutro onde seria possível a superposição de subjetividades. A fim de se investigar essa questão, a pesquisa parte para a análise do conto A terceira margem do rio, de João Guimarães Rosa (2001), e de obras homônimas que foram produzidas a partir dele: a canção de Caetano Veloso e Milton Nascimento e a instalação artística de Guto Lacaz.

O conto foi escolhido por ter influenciado a produção de obras nas mais diferentes linguagens, como teatro, cinema, telenovela, canção e artes visuais. Uma vez que o principal interesse da pesquisa se concentrava nas transposições de obras de linguagem verbal em obras de linguagem não verbal, ficou estabelecido que conto, canção e instalação artística formariam o corpus. Portanto, este estudo se empenhou em comparar as conexões entre a prosa, o texto poético (juntamente com a melodia) e as artes visuais.

Nesse sentido, foram feitas análises de imagens suscitadas pelo texto e pela obra de arte visual, e os efeitos provocados por cada linguagem em separado, conforme seus recursos estéticos. As reflexões partem do princípio de que cada linguagem artística é dotada de elementos expressivos próprios e, em consequência, alcança recepção também diferenciada. Ou seja, a recepção do conto, da canção e da obra visual corresponde ao trabalho realizado em torno dos elementos intrínsecos de cada linguagem, em somatória a todos os outros aspectos levantados pelos teóricos em torno da receptividade de uma obra. Os aspectos mais marcantes de cada uma destas linguagens foram expostos a fim de se definir os posicionamentos deste estudo em relação a elas. Sendo assim, algumas considerações acerca das diferenças entre poema, letra poética e prosa foram delineadas.

O conto apresenta uma imagem inusitada: um rio com três margens. Como é possível se imaginar tal fenômeno? Por meio da prosa, do texto poético e das artes visuais, cada autor 
apresentou a sua concepção de uma terceira margem do rio. Ao longo do texto, esta pesquisa também apresenta a sua. Porém, antes disso, procurou verificar os recursos estéticos e os meios artísticos com que cada obra, em sua especificidade, estabeleceu os intertextos e interdiscursos que ligam as três produções. Baseando-se nas considerações de Affonso Romano de Santana (2003), foi feito um estudo das ocorrências de estilizações e apropriações na arte contemporânea. Verificou-se, então, como foram realizadas as transposições de linguagem artística em cada uma das obras analisadas, destacando as habilidades e as técnicas empregadas pelos autores para comunicar a ideia de uma terceira margem por seus próprios recursos estéticos e estilo.

Os intertextos e interdiscursos têm se demonstrado como uma característica das produções artísticas contemporâneas. Embora os termos paródia, paráfrase e estilização sejam frequentemente usados para designar as relações intra e intertextos, aqui foram relacionados também aos processos comunicativos entre literatura e outras artes. O objetivo era extrapolar os limites do discurso enquanto texto para analisá-lo em suas versões visuais e na canção. Enfim, esses termos foram investigados ainda, quanto à sua aplicabilidade, por analogia, aos relacionamentos interartes.

O estudo dos relacionamentos interartes tem se tornado cada vez mais necessário por suas inserções frequentes nas produções artísticas contemporâneas. A forma como esse fenômeno é inserido e utilizado na sociedade, especialmente no ambiente escolar, deve ser amplamente investigada e discutida. Por se tratar de uma manifestação que propicia o diálogo entre obras de diferentes linguagens e contextos, é importante propor estratégias que visam divulgar, produzir e analisar obras que se utilizam desse recurso. Para a realização desse empreendimento, metodologias de leitura e crítica das áreas de arte e literatura foram mescladas.

A estrutura formal desta pesquisa foi concebida no intuito de estabelecer interseções. A imagem do rio trimargeado de Guimarães Rosa está presente em cada um dos capítulos, que representam as três margens do rio. Com isso, propõe-se demonstrar que os interrelacionamentos na arte contemporânea é também uma forma de expressar a busca da alteridade. Os intertextos e interdiscursos na arte buscam, de alguma forma, suprir as lacunas existentes entre os seres humanos, independentemente do tempo e do espaço.

O primeiro capítulo se inicia com uma reflexão sobre o sujeito e a afirmação de identidades. O posicionamento do sujeito que busca identificar-se, autoafirmar-se é à primeira margem do rio. Nesse sentido, o conto é requisitado para formar uma alegoria, que apresenta um sujeito imerso em si mesmo, mas que deseja ir ao encontro do próximo, o Outro 
desconhecido que habita a segunda margem. Seguindo essa linha de pensamento, cada estilo artístico em questão passa a ser analisado em suas singularidades, separadamente. Depois, a fim de elucidar alguns conceitos, apresentam-se as diferenças e semelhanças entre os tipos de textos, objetos desta pesquisa. Atenção especial foi dada à instalação artística, por ser uma arte de vanguarda que ainda suscita muitas dúvidas e curiosidades sobre sua afirmação no campo artístico. A obra de Guto Lacaz foi apresentada em duas versões: o projeto inicial de 1998, feito para a exposição A imagem do som de Caetano Veloso, e a instalação artística que foi exposta na marquise do Parque Ibirapuera, São Paulo, em comemoração ao dia mundial da água, em março de 2010.

No segundo capítulo foram formuladas análises sobre alteridade, considerando-se as reflexões de Jacques Derrida (2002), em diálogo com as ideias observadas no conto, na canção e na instalação artística. Neste capítulo buscou-se verificar de que maneiras literatura, música e artes visuais intentam comunicar a alteridade das pessoas, da natureza e das coisas valendo-se de sua linguagem e recursos estéticos. Foram feitas algumas considerações sobre leitura, conforme teóricos da Estética da Recepção, e sobre interpretação sob os pressupostos de Humberto Eco (2004/2005). Também foram averiguadas as ocorrências de intertextos, interdiscursos, estilizações e apropriações nas obras estudadas. O respeito e consideração que se devem ter pelas ideias, pensamentos e impressões dos outros, perpassa todo o texto.

O terceiro capítulo é mais longo porque nele há confrontação das ideias apresentadas nos capítulos anteriores sobre identidade e alteridade, associadas à literatura e outras artes, e também porque transcreve o relato concernente ao caso concreto analisado. A terceira margem é um espaço mítico, transcendente, por isso este capítulo traz considerações sobre o sagrado nas artes e na literatura. O objetivo do capítulo é favorecer interseções de ideias. Nesse sentido, foram aprofundadas as considerações sobre literatura e outras artes como espaço de superposição de subjetividades, conforme estudos de Maurice Blanchot (2005/2011). Mito, mímesis e representação efeito foram analisados e associados a recursos estéticos empregados pelos autores na elaboração de discursos. As conexões produtivas entre artes visuais e literatura foram analisadas mais detalhadamente por se tratar de linguagens bastante díspares e, no entanto, formarem, ao longo da História, uma intensa cadeia de relacionamentos interartes. Por fim, há a apresentação do processo de elaboração, exposição e análise da instalação artística Mensagem a um general. 
Figura 1 - A terceira margem do rio: obra de Guto Lacaz para o projeto A imagem e o som de Caetano Veloso, organizado por Felipe Taborda (1998).

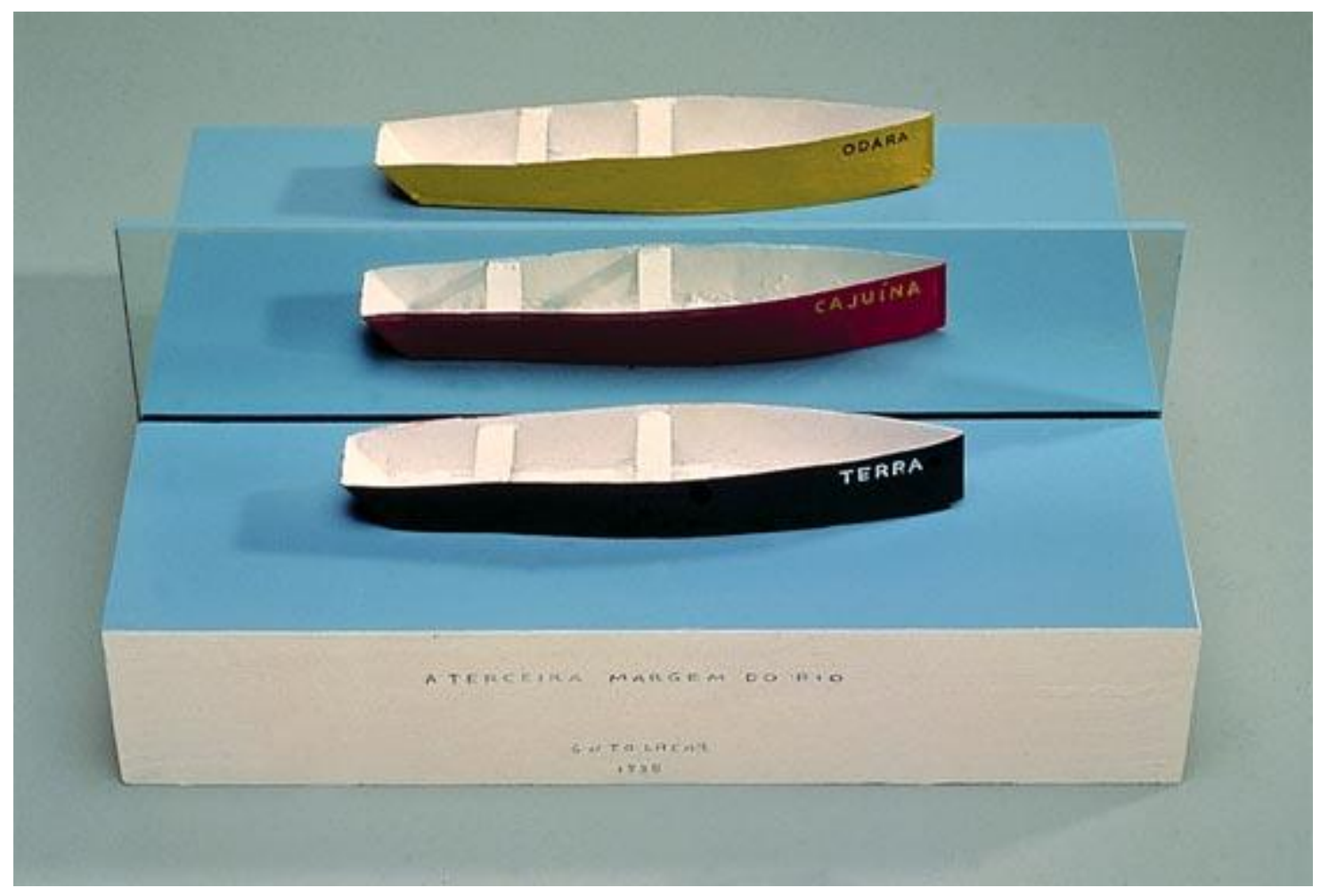

a) Vista frontal da maquete

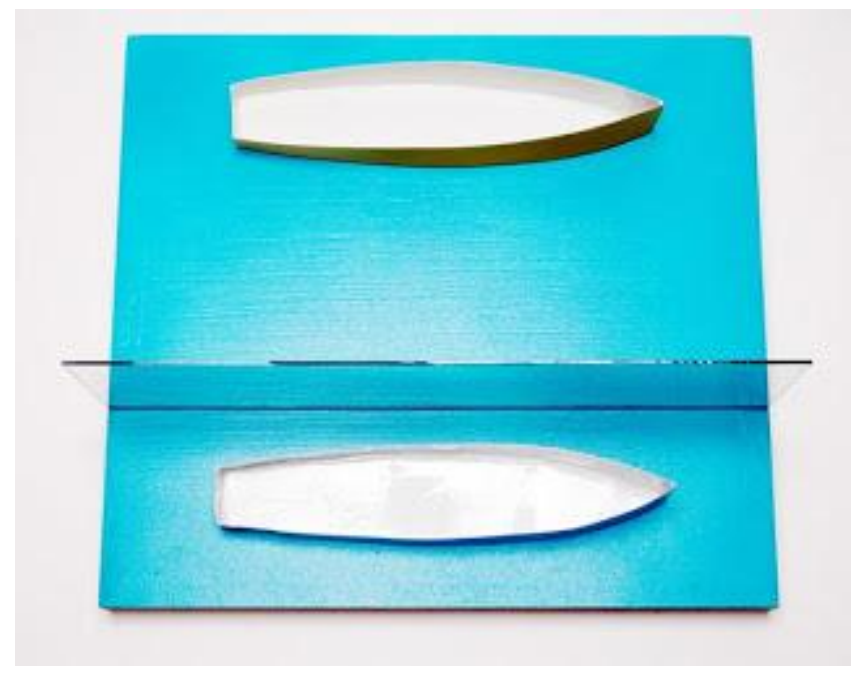

b) Vista panorâmica da maquete 
Figura 2 - Instalação artística de Guto Lacaz que foi exposta na marquise do parque Ibirapuera, São Paulo, em comemoração ao dia mundial da água (março 2010).

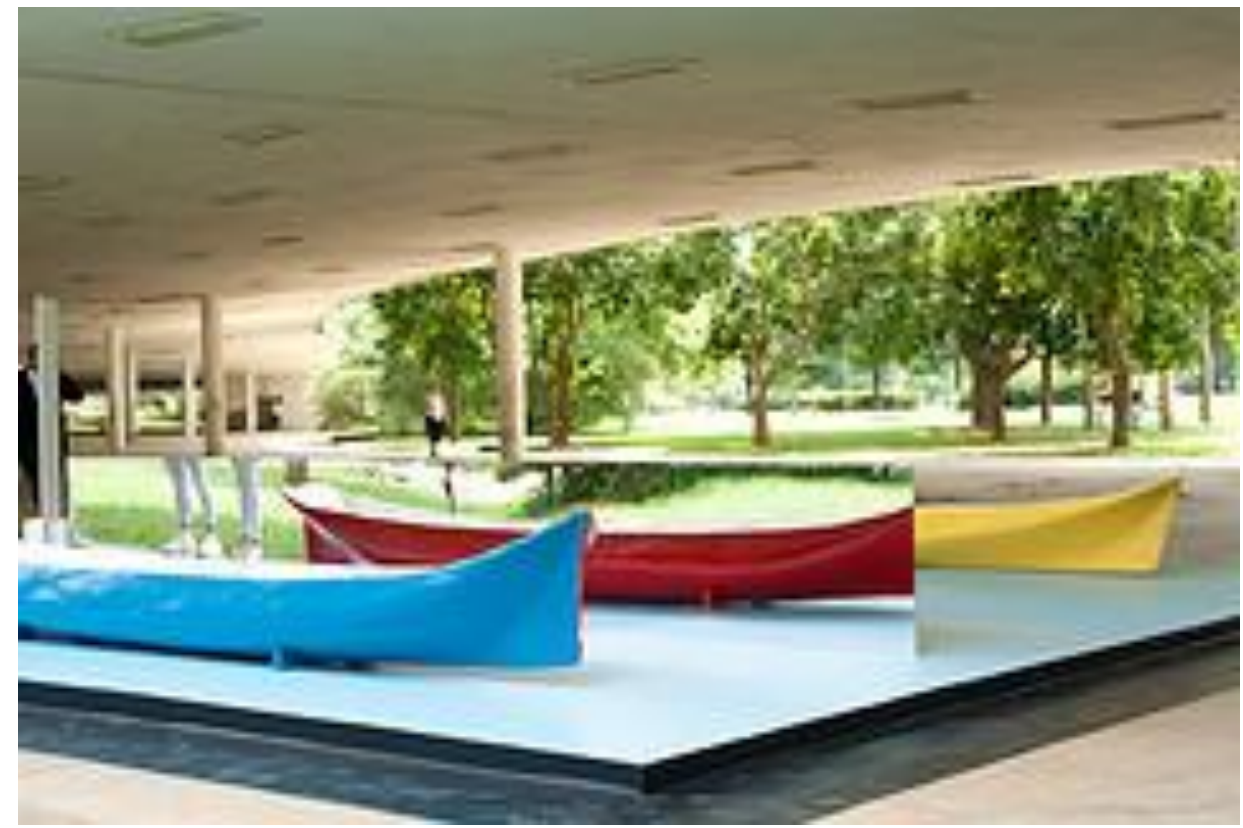

a) As três canoas (Terra, Cajuína e Odara) vistas por meio do artifício do espelho.

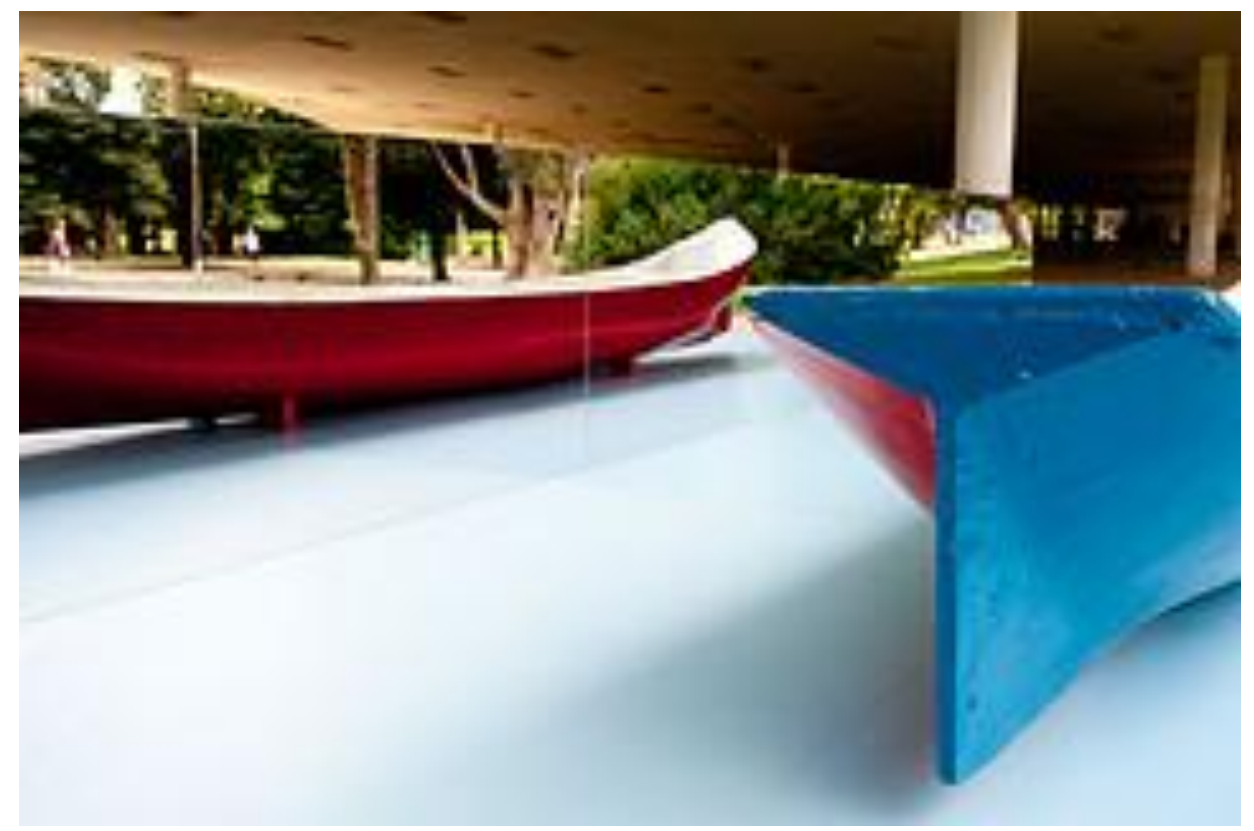

b) Vista das canoas Terra e Cajuína (no espelho). 


\section{Primeira margem: Eu}

"O "Ele" que toma o lugar do "Eu", eis a solidão que sobrevém ao escritor por intermédio da obra."1

“Às vezes quase acredito que eu mesmo, João, sou um conto contado por mim mesmo." 2

A atitude humana de postar-se diante de um rio e deixar-se ali permanecer em contemplação pode ser comparada a atitude de quem se coloca diante do outro com intenções de estabelecer com ele alguma interação. O rio a que este estudo se refere é o rio trimargeado de Guimarães Rosa. Um rio imenso, de tão largo quase não se pode ver a outra margem, entretanto, por entre as ondulações de suas águas há uma pequena canoa. Ninguém está convidado a tomar parte na canoa e navegar rio abaixo, rio acima, com o canoeiro solitário que é seguido pelos olhares enviesados, gaze $e^{3}$, como os definiu Jacques Lacan (1901-1981). A canoa foi feita sob medida para o canoeiro; ela não comporta mais do que sua frágil figura.

Aquele que se coloca diante do rio ocupa, numa ótica ontológica, a primeira margem e, ao percorrer os olhos para além da imensidão do espaço, mal se pode crer que haja, ao final de tanta água, uma segunda margem. A distância que existe entre as margens é muito grande, portanto, não é possível perceber com clareza o que há do outro lado do rio. Apesar disso, olhares de medo, anseios, especulações, conceitos e pré-conceitos são lançados sobre a outra margem. "O olhar frequentemente expressa atitudes sobre as quais o espectador pode não estar consciente, sejam elas de medos, ódios ou desejos projetados no outro.” (BURKE, 2004, p.156). A distância impede uma visão completa do que há na outra margem, apesar disso, muitos olhares se dirigem diretamente a ela, sem que antes se detenham ao menos por um breve instante sobre as águas profundas do rio que terá de ser atravessado por quem deseja realmente alcançar a outra margem.

O conto A terceira margem do rio relata um acontecimento extraordinário: a história de um homem que constrói uma canoa e decide ir viver dentro dela, num rio, afastado do convívio familiar para sempre. Ele não aporta numa margem, nem na outra, mas permanece sempre dentro do rio, inexplicavelmente. Um dos filhos, o narrador da história, tenta durante toda a vida compreender as razões que impuseram ao pai tamanho sacrifício.

"Nosso pai", como o narrador se refere ao canoeiro enigmático, nunca mais disse palavra alguma, permanecendo indiferente às tentativas das pessoas de estabelecerem com ele

\footnotetext{
${ }^{1}$ Maurice Blanchot, O espaço literário, 2011, p. 19.

2 João Guimarães Rosa, em entrevista a Günter Lorenz - Diálogo com Guimarães Rosa.

${ }^{3}$ Conforme a teoria psicanalítica de Jacques Lacan gaze é um estado de ansiedade decorrente da consciência de que se pode ser visualizado.
} 
alguma comunicação e, principalmente, de dissuadi-lo daquela ideia de ir viver no rio. Ninguém consegue compreender a atitude de "Nosso pai". Sua família e as pessoas dos arredores procuram trazê-lo de volta à margem de onde ele saiu. Porém todos se encontram fixos na primeira margem, que será considerada aqui o lugar do sujeito solar, central. A primeira margem representa, neste estudo, o Eu racional, que busca definir tudo e todos a partir de suas próprias convicções.

Conforme afirma Levinas em Totalidade e infinito (1980), "a filosofia ocidental foi, na maioria das vezes, uma ontologia: uma redução do Outro ao Mesmo" (ibidem, p. 31), mas a relação como o Outro é transcendente, não comporta os limites racionais do sujeito. "A relação com outrem, portanto, não é ontologia.” (idem, 2004, p. 29). Apesar disso, o sujeito que intenta adaptar o Outro ao seu modo de ser e de pensar é aquele que vive na totalidade e, dentro dessa totalidade, todas as pessoas devem se ajustar a um padrão pré-determinado. Formam-se, então, os grupos, as comunidades onde todos são o Mesmo, sem muito espaço para as diferenças. A atitude inusitada de "Nosso pai" era desconcertante, trazia incômodo aos demais e até mesmo vergonha para a família.

A relação ontológica tem a tendência de reduzir o Outro aos limites do Mesmo, estabelecendo assim, a sujeição do ente pelo ser. Apesar disso, “o eu não é um ser que se mantém sempre o mesmo, mas o ser cujo existir consiste em identificar-se, em reencontrar sua identidade a partir de tudo o que lhe acontece." (idem, 1980, p. 24). Logo, o Mesmo é aquele que volta sempre a si, pois seu poder de identificação lhe permite atribuir ser aos outros, não em direção à sua exterioridade, mas por analogia à interioridade do Mesmo.

Quem insiste em permanecer na primeira margem, ou seja, em si mesmo, enxerga no outro uma ameaça. A fim de legitimar sua identidade, julga ser preciso negar a identidade alheia. Acomodado à segurança da primeira margem, o sujeito busca compreender a segunda, e julga que aí está fundada a sua existência: no pensamento, na compreensão da exterioridade. Compreensão que suscita equívocos, posto que o sujeito não se afasta do Eu para ir em busca do Outro e, em consequência, termina por negar sua identidade. Como afirma Bakhtin (1997, p.55), "a consciência vive suas próprias fronteiras exteriores de uma maneira diferente, viveas numa relação consigo mesma.” Quanto à compreensão do ser, Levinas demonstra que,

Compreender o instrumento não consiste em vê-lo, mas em saber manejá-lo; Compreender nossa situação no real não é defini-la, mas encontrar-se numa disposição afetiva; compreender o ser é existir. Tudo isso está a indicar, ao que parece, uma ruptura com a estrutura teorética do pensamento ocidental. Pensar não é mais contemplar, mas engajar-se, estar englobado no que se pensa, estar embarcado - acontecimento dramático do ser-no-mundo. (idem, 2004, p. 23). 
Mas a existência do ser e a sua consciência em relação à realidade, não esgotam as possibilidades de interação entre o sujeito e as coisas. "Nosso pai", embora tenha embarcado na canoa com intenções de navegar rio abaixo, rio acima indefinidamente - por isso mandara construir uma canoa firme, feita para durar uns 30 anos na água - esse gesto desencadeou outros acontecimentos. Ou seja, o pensamento, a compreensão e a consciência da realidade não comportam as nuanças da existência, pois cada gesto, ainda que inadvertidamente, acarreta novas situações, mesmo que à revelia das intenções daquele que o produziu.

Fixar-se à primeira margem não exime o sujeito de sua responsabilidade para com o Outro. Entretanto, limita os alcances da consciência em relação ao Outro, uma vez que o sujeito insiste em manter-se em sua interioridade. Desta forma, considere-se que

\footnotetext{
o vivente, portanto, não é sem consciência, mas tem uma consciência sem problemas, quer dizer, sem exterioridade, mundo interior cujo centro ocupa, consciência que não se preocupa em situar-se em relação a uma exterioridade, que não se capta como parte de um todo (pois ela precede todo apreender), consciência sem consciência, à qual corresponde o termo (que não dissimula menos contradições) de inconsciente ou de instinto. A interioridade que, para o pensante, se opõe à exterioridade, se exerce no vivente como ausência de exterioridade. A identidade do vivente através de sua história não tem nada de misterioso: o vivente é essencialmente o Mesmo, o Mesmo que determina todo Outro, sem que o Outro determine jamais o Mesmo. (ibidem, p. 35/36).
}

O sujeito cartesiano (pensante, racional, consciente), é então, um ser que vive na totalidade, pois em seu pensamento encerram-se todas as coisas, inclusive o Outro. Todavia, para Levinas a totalidade do pensante precede todo apreender, já que ele não é parte do todo, ele é o todo, ou seja, de sua interioridade, ele determina toda exterioridade. Os acontecimentos em sua história vão reafirmando a sua identidade, o que faz dele essencialmente o Mesmo, ainda que em diversas versões de si. E, de si Mesmo, o pensante determina o Outro, porém, por manter-se estagnado na primeira margem, não se disponibiliza a ser determinado também pelo Outro.

No conto, o filho é aquele que se mantém na totalidade. Ele busca compreender a atitude do pai, porém não consegue sair de si mesmo para ir ao encontro do pai. Não que ele siga sendo sempre o mesmo, mas que, em sua busca por compreender o Outro, apenas alcança reafirmar-se, pois sua busca parte sempre de si mesmo e a si mesmo retorna. As mudanças que vão ocorrendo em sua vida, na cidade, nas pessoas do lugar e nele próprio pela passagem dos anos, em vez de promoverem a exteriorização de sua existência, fazem que ele deseje cada vez mais fixar-se a fim de reencontrar sua identidade perdida quando da entrada do pai na canoa. 
A obstinação do narrador pelo pai que se lançou ao rio dentro de uma canoa para nunca mais retornar, nada mais é do que a obstinação do pensante por si mesmo. É a sua própria identidade que o filho deseja reencontrar. Mas ele não pode seguir com o pai, pois a canoa foi feita para uma pessoa apenas. Também não pode ficar sem o pai, pois a partir dele que foi construída a sua identidade. Eis o dilema da totalidade do ser. Em si não comporta o Outro, entretanto, a partir de si determina o Outro e, por não deixar-se também determinar, encerra-se em sua totalidade. Mas o Outro é o infinito.

\footnotetext{
O solipsismo, que aloja o mundo inteiro dentro da minha consciência, pode ser intuitivamente convincente, ou ao menos compreensível, mas seria intuitivamente de todo incompreensível alojar o mundo inteiro e a mim mesmo na consciência do outro que, de modo não menos evidente, é somente uma parte ínfima do mundo imenso. (BAKHTIN, 1997, p. 58).
}

Enquanto mantém-se na primeira margem, esse sujeito é o "Eu", um ego que se recusa a sair de si e que, numa sociedade, se torna uma mesmidade, palavra que Ricoeur, em seu livro O si-mesmo como outro (1991), utiliza para designar o sujeito estável, identificável. Ou seja, um sujeito social, constituído pelo que se diz dele em determinadas circunstâncias, sem singularidades. As pessoas da cidade, ao tentar compreender o que havia acontecido a "Nosso pai", tentavam encaixá-lo em alguma designação, como "doido" ou "profeta". Quanto ao filho, embora também não conseguisse compreender a atitude de "Nosso pai", observava e interpretava os acontecimentos, porém sem êxito.

Ainda conforme Ricoeur, o sujeito idem retorna a si mesmo após as reflexões sobre os signos e as obras que encontra no mundo e que aí já se encontravam antes da sua existência. No entanto, para que essa reflexão seja realizada, é necessário contato e interpretação dos signos e das obras. Assim, a mesmidade do sujeito só pode ser avaliada na medida de sua permanência no tempo, uma vez que o contato e a interpretação não podem ser desenvolvidos de forma imediata.

$\mathrm{O}$ "Eu", que se posiciona e se identifica na primeira margem é aquele que evita confrontar-se com o Outro, que apenas vislumbra uma segunda margem, e dela chega a fazer confabulações, porém não empreende o movimento e o esforço que são necessários para se atingir a outra margem. Portanto, suas concepções a respeito do Outro ocorrem de forma imediata e por analogias baseadas numa unicidade de ideias e em suas próprias experiências.

Em contrapartida, Ricoeur aponta para a ipseidade do sujeito que se autodetermina a partir de sua história de vida e do encontro com o Outro. O sujeito ipse, então, é o ser único, singular, constituído pelo que ele próprio afirma de si e também de suas relações com o 
Outro. Esse Outro pode ser compreendido como o outro social e também como a natureza, os objetos, as situações, os acontecimentos, os signos, as obras, afinal, tudo que promova interação, reflexão e interpretação.

Entretanto, conforme preconiza Ricoeur, ao descobrir-se como si mesmo, o sujeito está admitindo-se, então, como um outro. O sujeito ipse está em constante produção de si e, por isso, escapa ao Outro: "Nossa tese constante será que a identidade no sentido de ipse não implica nenhuma asserção concernente a um pretenso núcleo não-mutante da personalidade." (ibidem, p.13). Afinal, multiplicam-se as identidades do sujeito no tempo, porém elas tendem mais à repetição e reafirmação de um ponto de partida do que a uma mudança verdadeira.

A experiência estética favorece o desenvolvimento da identidade pessoal, uma vez que, conforme Ricoeur, é possível verificar na ficção a coexistência da mesmidade e da ipseidade. No confronto entre história e ficção, o sujeito vai configurando a sua identidade, ou seja, “a literatura é um vasto laboratório onde são testadas estimações, avaliações, julgamentos de aprovação e de condenação pelos quais a narrativa serve de propedêutica à ética" (ibidem, p. 140). Quanto a esse aspecto da literatura e quanto à sua relação com o Outro, verifica-se que ela apresenta e oculta as muitas faces do Outro, e daí a sua relevância aos estudos de filosofia e demais áreas que tratam das questões individuais e sociais do sujeito.

Em literatura, portanto, é possível observar que, em coexistência com o sujeito ipse, há o sujeito idem. Em outras palavras, as narrativas históricas e ficcionais proporcionam ao sujeito a manutenção de sua identidade, porém em constante processo de reconfiguração no tempo. O sujeito idem, de sua posição fixa nesta primeira margem do rio, assiste à canoa de Guimarães Rosa, que passa alterando a paisagem, riscando com seu casco as águas, formando nelas um desenho, uma imagem. Mas, o que é uma imagem? E quais aspectos sensoriais ela pode despertar?

Embora frequentemente usada para definir elementos visuais, captados pela retina, a palavra imagem, para efeitos deste estudo, abarcará definição bem mais abrangente. Segundo Ricoeur (2000, p.317), há um certo preconceito na teoria da imaginação, que reduz a metáfora à imagem mental, e imagem a um fator psicológico. Dessa forma, intenta-se aqui superar esse preconceito, ampliando a discussão sobre a imagem em seus aspectos sensoriais.

Para isso, parte-se do princípio de que a visão é apenas um dos meios sensórios de informação e de que se pode produzir e ler imagens utilizando todos os sentidos. Consequentemente, imagem é processo cognitivo elaborado a partir de determinado evento/realidade palpável ou sensorial. De acordo com Elaine Caramella: 
Imagem é substituição, fruto de interferências associativas que se estabelecem através de movimentos sinestésicos. Imagem envolve, pois, rede de imagem, um simulacro que o processo cognitivo constrói, a partir da inter-relação, sobreposição e penetração de fragmentos de informação, advindos dos órgãos sensoriais (idem, 1998, p. 140).

Acontecimentos extraordinários quase sempre são marcados por imagens, uma vez que elas costumam permanecer por mais tempo na memória. O narrador, embora já idoso, guarda na memória a imagem associativa que se formou em sua mente quando da partida de "Nosso pai": "E a canoa saiu se indo - a sombra dela por igual, feito um jacaré, comprida longa." (ROSA, 2001, p.80). A sombra da canoa no rio pareceu ao menino um jacaré, imagem mental formada da sobreposição da sombra com o conhecimento prévio das formas do animal.

Do mesmo modo, arte e literatura estimulam a formação de imagens mentais por meio de cadeias associativas interpretadas a partir de formas conhecidas. Admitindo-se, portanto, que informações e fragmentos de informações percebidos pelos órgãos sensoriais, quando processados cognitivamente, podem ser traduzidos em imagens, chega-se à conclusão que a diversidade de meios com que a arte contemporânea se utiliza para interpolar o espectador favorece grandemente o desenvolvimento do imaginário social. Partindo-se destas considerações é possível verificar que texto, canção e artes visuais, cada um por seus meios, conduzem a um processo de formulação de imagens diferente e, assim, contribuem para que haja elaboração de significados mais abrangentes e de maior alcance cultural e social.

Entretanto, resta ainda estabelecer em que sentido a análise de imagens é importante quando se pretende formular um estudo interartes, e quais os tipos de imagens devem ser considerados. Conforme já foi mencionado, cada arte se utiliza de meios próprios para suscitar no receptor a imaginação. Compreender como se dá esse processo ajuda a formulação de ideias sobre a transposição de elementos de uma linguagem artística a outra. Consideradas produto de um processo cognitivo que seleciona e associa informações a partir de inúmeras possibilidades sensoriais, é importante também salientar que a classificação das imagens aqui é feita conforme seus meios de produção e assimilação.

Platão (Rep. 509 e - 510 a) definiu duas classes de imagens: a primeira são as sombras e os reflexos produzidos sem interferência humana, como o sol e a lua que aparecem pela manhã e à noite nas águas de um rio. Ou como a imagem refletida no espelho que, apesar de fabricado por mãos humanas, reflete uma imagem natural daquilo que se apresenta a sua frente. A segunda classe de imagens são as artificiais, ou seja, aquelas que necessitam da 
interferência humana para que possam existir. O desenho, as letras, a fotografia (considerando que a imagem capturada por ela carece de algum suporte material em que fixar-se, como o papel ou a tela de um computador). Dessa forma, algumas imagens são fabricadas, enquanto outras são apenas projetadas, sem a manipulação de artefatos materiais.

Independente de sua materialização ou não materialização, imagem é aquilo que traz de volta o que está ausente. Há sempre um objeto que precede a imagem e que deve se ausentar para que ela encontre, nessa ausência, o seu espaço. Portanto,

\begin{abstract}
a imagem, segundo a análise comum, está depois do objeto: ela é a sua continuação; vemos, depois imaginamos. Depois do objeto viria a imagem. 'Depois' significa que cumpre em primeiro lugar que a coisa se distancie para deixar-se capturar. (BLANCHOT, 2011, p. 279).
\end{abstract}

Desta primeira margem do rio, que representa o $\mathrm{Eu}$, intenta-se avistar a segunda margem, que representa o Outro. Tem-se dela uma imagem formulada a partir do lugar onde se fixa o Eu. Porém, conforme Blanchot, é necessário que o objeto se distancie para deixar-se capturar. A distância, porém, apaga o objeto em benefício de sua imagem, então, o que se obtém da segunda margem (o Outro) é apenas uma imagem distorcida; quanto maior a distância a que o sujeito se posiciona em relação à segunda margem, maior será a distorção.

Nos textos e na instalação artística aqui analisados, serão observadas também as imagens produzidas pela mente a partir de palavras, de figuras e de estímulos sensoriais táteis e auditivos. Joly assim as definiu:

\footnotetext{
A imagem mental corresponde à impressão que temos quando, por exemplo, lemos ou ouvimos a descrição de um lugar, impressão de ver quase como se lá estivéssemos. Uma representação mental é elaborada de um modo quase alucinatório e parece pedir emprestadas as suas características à visão. Vê-se. (idem, 2007, p 20).
}

Estas imagens, todas elas artificiais, serão consideradas projeções mentais (quando formuladas a partir do texto/imaginação) ou produto visual (quando formuladas com materiais concretos/palpáveis). A imagem da sombra que o narrador associou em sua mente a um jacaré se trata de projeção mental, pois a sombra estimulou a mente a produzir a imagem do jacaré, da mesma forma que o texto estimula a produção de imagens mentais diversas. Portanto, as imagens mentais não serão aqui consideradas menos artificiais do que as imagens concretas, uma vez que ambas são originadas das impressões humanas. As imagens concretas, por sua vez, serão assim consideradas conforme a sua materialização. 
De qualquer maneira, algumas destas imagens fornecem pistas da distância a que elas se encontravam do objeto capturado. Ou seja, a nitidez da imagem vai se perdendo gradualmente com a distância. Quanto mais distante o espectador se encontra do objeto, mais distorcida se apresenta a imagem por ele capturada.

Dessa forma, quando aqui se faz referência à imagem, isto significa duas realidades distintas: imagem mental (impressões do espectador) e imagem concreta (realização material da obra). Por imagem mental, têm-se as formulações suscitadas na mente a partir de incentivos externos ou internos, porém desprovidas de materialidade. Em outras palavras, são as impressões que são formuladas na mente quando provocada. O conto de Guimarães Rosa, ao descrever um rio "largo de não se poder ver a forma da outra beira", provoca na mente do leitor uma imagem particular do rio; imagem esta provocada pelas palavras, mas que não possui existência alguma fora da imaginação, portanto, destituída a imagem de sua materialidade. Por outro lado, quanto à imagem concreta, considerem-se as produções visuais, também construídas a partir de incentivos internos ou externos, mas que foram elaboradas, enfim, em suporte material.

A instalação artística de Guto Lacaz apresenta suporte azul que sugere um rio, é imagem concreta que provoca significados conduzidos pelo artista. Vale acrescentar que o artista conduz a significação da obra, porém não a determina, uma vez que a obra de arte pode suscitar outras interpretações. Quanto à formação de símbolos visuais que, por vezes, uma imagem pode se tornar, Joly estabelece diferenciações entre símbolo e metáfora, explicando que o primeiro pode não ser interpretado. Utiliza como exemplo a pomba da paz que pode ser percebida como símbolo da paz ou simplesmente como imagem de uma pomba. (idem, 2007, p. 140). Então, as imagens-símbolo, diferentemente das metáforas utilizadas na linguagem verbal, tendem a suscitar as interpretações sugeridas pelo autor, ou simplesmente a serem tomadas pela sua forma, sem que haja maiores ampliações de seu significado.

\subsection{Recursos estéticos: singularidades}

Os relacionamentos entre as artes podem ocorrer por meio de correspondências entre códigos e símbolos quando, então, se busca criar analogias entre as diferentes linguagens. A correspondência ocorre quando se procura, por exemplo, determinar a cor do som, o desenho da coreografia, a música de uma pintura ou poema numa escultura.

De outro modo, há também os relacionamentos interartes que buscam mesclar recursos estéticos de duas ou mais linguagens artísticas, formando uma arte híbrida. A poesia visual 
contemporânea é um exemplo desse tipo de correspondência em que imagem e palavra se unem para formar uma composição artística significativa. O mesmo ocorre com os poemas concretos, ao se formarem desenhos com as palavras. A canção é considerada uma arte híbrida, já que é composta do texto poético e da melodia.

Entretanto, neste estudo interartes de A terceira margem do rio, a correspondência não se dá apenas por analogias ou pelo hibridismo, mas também pela tradução intersemiótica, uma vez que as obras se utilizam de elementos expressivos próprios para dar conta de relatar, cantar e mostrar a mesma história.

A proposta deste tipo de correspondência é, portanto, a transposição de linguagens artísticas, o que se apresenta como uma espécie de tradução. Contudo, diferentemente do trabalho de tradução de um texto de uma língua a outra, que ocorre dentro de um mesmo sistema de signos, ou seja, os da linguagem verbal, na tradução intersemiótica, isso se faz entre diferentes sistemas de signos.

Quando se trata de tradução intersemiótica, o que se observa é a maneira como cada linguagem artística conserva os seus elementos expressivos e se utiliza de recursos estéticos específicos para comunicar uma mensagem anteriormente apresentada por obra de linguagem distinta. Para tanto, é importante compreender certos sistemas de sinais inerentes a cada linguagem, uma vez que

a criação de sistema de sinais é fundamental para o intercâmbio de mensagens entre o homem e o mundo. Cada sistema de sinais constitui-se segundo a especialidade que lhe é característica e que pode ser articulada com os órgãos emissoresreceptores, isto é, com os sentidos humanos. (PLAZA, 2003, p. 45).

Assim, cada linguagem artística, conforme sua singularidade compõe-se de um sistema de sinais por meio do qual alcança os sentidos humanos, emitindo mensagens e causando efeitos específicos. Embora todos os sentidos humanos sejam amplamente estimulados por meio de obras artísticas, principalmente as de vanguarda, pode-se averiguar que

dentre os sentidos humanos, três foram os que historicamente se caracterizaram como geradores de extensões capazes de prolongar e ampliar a função de cada um desses sentidos em meios produtores de linguagem. São eles: o visual, o tátil e o auditivo. (ibidem, p.45/46).

As obras analisadas neste estudo propiciam investigar os efeitos comunicativos do conteúdo explorado no conto A terceira margem do rio, por cada um desses três sentidos, conforme a linguagem usada na transposição. Pela leitura do conto se verifica, portanto, como 
a informação estética se processa visual (conforme as imagens que a palavra suscita na mente do leitor) e auditivamente, formando significados. Embora a canção também processe informação estética por meio dos mesmos sentidos que o conto, o efeito causado no receptor é diferente porque diferentes são as formas com que a canção se utiliza das palavras e dos sons. Já a instalação artística, ao se utilizar dos sentidos visual e tátil, de maneira interativa, amplia os modos de percepção da mensagem.

Assim, é importante observar que a transposição de ideias de uma linguagem artística a outra proporciona aos receptores das obras experiência estética diferenciada. Embora se trate da mesma ideia, é possível transmiti-la por meio de sistemas de signos diversos e, desse modo, alcançar diferentes públicos, conforme os sentidos que cada obra faz despertar.

Todos os sentidos interferem significativamente na apreensão do real e também da obra. Isto significa que

os receptores no ouvido interno nos informam da nossa posição em equilíbrio durante o movimento, assim como a posição da cabeça e do corpo. Os receptores do tato, instalados na pele, nos informam constantemente das qualidades do ambiente e, sobretudo, o movimento sacádico dos olhos está coordenado com o movimento e a manipulação de objetos no mundo. (PLAZA, 2003, p. 46).

Artes e literatura, ao provocar assim os sentidos, realizam o que Ricoeur chamou de identidade narrativa, pois as obras auxiliam o sujeito na apreensão do real. Ao produzir e apreciar as obras de arte e da literatura, o sujeito configura a sua própria existência e se torna capaz de forjar para si uma narrativa, deixando de ser apenas idem, ou seja, aquele de quem se diz coisas, para se tornar também ipse, aquele que produz e difunde a narrativa de si, junto com os outros. Afinal,

não somos somente sujeitos, somos também objetos do e no mundo, pois nos percebemos dentro do mundo, isto é, nos ouvimos, nos tocamos, nos vemos. Ao perceber o mundo, percebo meu eu. Á sensação de estar "aqui" corresponde à sensação de estar "ali”, em conflito. (PLAZA, 2003, p.46).

Porém, não é possível ao sujeito captar o Outro, ou a realidade que o cerca, completamente. Nem mesmo por meio das artes e de suas conexões isso é possível, pois "a representação sígnica nunca foi uma tentativa de apreender o real como um todo, pois isso está além da capacidade humana, quer dizer do próprio signo”. (ibidem, p. 47).

Embora as inter-relações entre as artes possibilitem ao receptor experimentar, a partir de uma mesma ideia, diferentes sensações estéticas e, assim também, configurar melhor o seu lugar no mundo, não intentam apreender o real. Ou seja, a transposição de uma linguagem 
artística a outra não é uma espécie de competição em que se busca averiguar por qual signo melhor se reproduz a realidade.

Da mesma forma, embora se produzam narrativas a respeito dos outros e de si, elas são apenas representações baseadas na percepção daquele que a produziu. Podem auxiliar no desenvolvimento pessoal e na afirmação de identidades. Também podem ser importantes, a depender da maneira como são usadas, porque servem de reflexos com os quais se orientar, se identificar, alcançar prazer estético, mas não como determinação de realidades, uma vez que

cada sentido capta o real de forma diferenciada e as linguagens abstraem ainda mais o real, passando-nos a noção de realidade sempre abstrata que possibilita as linguagens adquiridas toda uma dimensão concreta na sua realidade sígnica. Não há reflexo ponto-a-ponto entre o real e a representação que dele se faz. E isto tem sua raiz na própria percepção, visto que a incompletude da percepção em relação ao real gera a inevitável incompletude do signo. (ibidem, p. 47).

Cada meio artístico pelos quais se expressam a realidade, os sentimentos e os pensamentos produzidos pelo ser humano são dotados de signos e de elementos expressivos próprios. Naturalmente, devido à sua singularidade, cada meio artístico provoca estímulos sensoriais diversificados. Estes estímulos, somados à perceptividade própria de cada indivíduo ou de uma comunidade, auxiliam na significação da obra.

A literatura, ao utilizar-se da palavra como meio expressivo, produz os estímulos sensoriais que a leitura comporta. Está sujeita, portanto, aos limites e potencialidades da palavra para gerar sentidos e significados. Seu canal de comunicação é o verbal e seu valor é determinado pela forma como os elementos verbais são distribuídos e trabalhados de modo a formar uma composição significativa, inteligível e harmoniosa.

O texto literário se constitui de conteúdo e forma. Em seu conteúdo, pode abarcar ideias, pensamentos, sentimentos e imagens imateriais suscitados pelo uso que se faz da palavra. Por meio da palavra o autor expressa seus pensamentos e consegue reproduzir a sua visão de mundo, recriar a realidade.

A forma diz respeito à maneira pela qual o artista se utiliza das palavras para expressar determinado conteúdo. O texto literário se caracteriza pelo uso da função poética da linguagem, pela seleção e combinação das palavras. Em prosa, como no conto, ou em versos, como na letra da canção, a intenção principal do texto é a própria mensagem, ou seja, é pela forma especial de se comunicar que o texto literário atinge seu objetivo.

Os elementos expressivos utilizados pelo autor de literatura são a polifonia, a plurissignificação, a desautomação da percepção, a conotação. A polifonia permite que a 
palavra seja atribuída a diversos personagens e, assim, sejam verificadas as diferentes possibilidades expressivas de indivíduos e grupos sociais distintos. No conto em questão, a narrativa em primeira pessoa dá voz ao personagem narrador e, por meio dele, a outros personagens, como à mãe que, em sua fala: “- Cê vai, ocê fique, você nunca volte!” (Rosa, 2001, p.80) demonstra ser uma mulher firme, determinada. A letra da canção atribui voz até mesmo às coisas: "oco de pau que diz: 'Eu sou madeira", Dessa forma, a literatura se apresenta como um campo onde se misturam muitas vozes, legítimas e ilegítimas, autênticas e estereotipadas.

Pela plurissignificação as palavras assumem diversos significados, dependendo do contexto e da forma como são usadas. Guimarães Rosa é bastante conhecido por seus neologismos e pelo uso incomum das palavras para alcançar sentidos surpreendentes. Quando o narrador diz: "- Sou homem, depois desse falimento? Sou o que não foi, o que vai ficar calado." (ibidem, p.85). A palavra "calado", embora signifique habitualmente a qualidade do que é silencioso, de poucas palavras, aqui Rosa a utilizou para significar a situação de algo que não aconteceu. Ou seja, a palavra "calado" que é utilizada em referência à falta de voz, foi utilizada em referência à falta de atitude, ao impedimento de uma situação que poderia ter acontecido. Também a letra da canção quando se refere à "asa da palavra", cria significados diversos para o substantivo "asa", além dos habituais que remontam à anatomia das aves.

Em sequência, ocorre ainda, a desautomação da percepção. Conforme Compagnon (1999, p. 41): “a literatura ou a arte em geral, renova a sensibilidade linguística dos leitores através de procedimentos que desarranjam as formas habituais e automáticas da sua percepção". A palavra "asa” é percebida geralmente por seus significados usuais, definidos nos dicionários. Na literatura, porém, a palavra e todo o contexto desafiam a percepção usual e convidam o leitor à liberdade, em vez da automatização da maneira de se perceber a linguagem e o mundo.

O uso predominante do sentido conotativo das palavras torna o texto literário mais subjetivo e sujeito a inúmeras formas de interpretação. O uso de figuras estilísticas, quando bem empregadas, auxilia na composição e compreensão da mensagem, porque o texto literário visa mais do que a simples informação, sendo também o resultado de um trabalho estético. Então, por se utilizar de recursos estilísticos e de uma linguagem mais conotativa, a leitura do texto literário requer habilidades de associação que relacionem todo o contexto, pois frases isoladas podem distorcer e até mesmo contrariar o seu significado geral.

Enfim, “as formas literárias não são diferentes das formas linguísticas, mas sua organização as torna (pelo menos algumas delas) mais visíveis.” (ibidem, p. 43). A 
organização do texto literário, em seu conteúdo e forma, visa à adequação comunicativa e estética da linguagem. Conteúdo e forma são, portanto, indissociáveis, muito embora em determinados contextos e situações um possa prevalecer sobre o outro conforme o objetivo que se intenta atingir. Sobre isso Bourdieu comenta:

Fazer triunfar a maneira de dizer sobre a coisa dita, sacrificar o "assunto", outrora diretamente sujeito à demanda, à maneira de o tratar, ao jogo puro das cores, dos valores e das formas, coagir à atenção para a linguagem, tudo isso equivale, em definitivo, a afirmar a especificidade e o caráter insubstituível do produto e do produtor, ressaltando o aspecto mais específico e insubstituível do ato de produção. (idem, 1996, p. 334).

Além disso, como obra de arte, a literatura tem o seu valor determinado de acordo com os períodos históricos e pelo contexto social ao qual é inserida. O texto literário é assim considerado conforme o julgamento estético que se faz dele, num determinado período, pelos que possuem conhecimento e autoridade nesse campo. De acordo com o autor:

A questão do sentido e do valor da obra de arte, como a questão da especificidade do julgamento estético, apenas pode encontrar sua solução em uma história social do campo associada a uma sociologia das condições da constituição da disposição estética particular que ele pede em cada um de seus estados. (ibidem, p. 324).

O texto literário é, pois o resultado que se obtém da forma de se utilizar a linguagem para comunicar ideias, juntamente com o contexto histórico e social que o recebe e analisa. Ao comunicar-se por meio do texto o artista se submete aos atributos da linguagem escrita que lhe permite expressar suas ideias e pensamentos, mas também aos julgamentos de valor que lhe serão imputados pela sociedade, em especial por aqueles dotados de poder de atuação no campo artístico.

Quanto à canção popular, trata-se de um gênero musical que tem como elementos a letra poética, a voz humana e o acompanhamento de instrumentos musicais. A letra poética é normalmente escrita em versos. Ritmo, melodia e harmonia fazem parte da composição de uma canção. As composições são criadas conforme o contexto, a sociedade e os valores sonoros definidos pela época e o lugar.

Ao agrupar os sons conforme a duração e intensidade, o compositor determina o ritmo da canção. A letra poética, embora possa apresentar ritmo próprio para leitura, como um poema, tem seu ritmo marcado principalmente pela composição musical. Enquanto o ritmo do poema se rege pelos sons das palavras e pela acentuação tônica, o ritmo da canção acompanha 
o compasso, que é dividido em tempos. Conforme Luiz Tatit (1995, p. 11): “compor uma canção é procurar uma dicção convincente. É eliminar a fronteira entre o falar e o cantar”.

A melodia pode ser definida como sequência de sons e silêncios em intervalos regulares, capaz de proporcionar sentido e fruição estética. Na canção popular, a voz humana conduz a melodia, acompanhada pelos instrumentos musicais. Ou seja, os instrumentos musicais emitem sons e notas diferentes, porém em harmonia com a voz do cancionista.

Portanto, harmonia se refere ao encadeamento dos sons executados simultaneamente. A superposição dos sons, organizados de maneira a combinarem-se entre si e cada um com o conjunto, forma a harmonia musical. A harmonia também está relacionada à elaboração de acordes (grupo de notas musicais tocadas simultaneamente). A formação de acordes é feita de forma específica para cada instrumento. Também é possível criar harmonia entre vozes humanas e instrumentos musicais.

A união de vozes em alturas e timbres diferentes pode formar uma composição harmoniosa e agradável. A harmonia entre as vozes dos artistas se deu por meio da altura, sendo a voz de Milton Nascimento mais grave e a de Caetano mais aguda, além da marcação dos timbres, em que Milton Nascimento fez a primeira voz e Caetano a segunda.

Quanto aos instrumentos, o uso da percussão marca o início da música com sons ocos que evocam uma atmosfera de mistério. A voz de Caetano chega a assemelhar-se a um sussurro, aumentando a sensação enigmática, semelhante à de quando alguém pretende revelar um segredo. A harmonia reafirma o clima de mistério, formando uma impressão que remete a lugares de mata fechada. Então, a introdução de um chocalho lembra também os perigos existentes às margens dos rios, como o de deparar-se com serpentes.

Enfim, a elaboração da harmonia na canção de Caetano Veloso e Milton Nascimento consegue transmitir sensações que lembram a ambientes beira-rio, com seus enigmas e perigos iminentes. Os sons ocos e sibilantes favorecem a atmosfera de rio em mata fechada. Então, a voz sussurrante, que vai se libertando aos poucos até tornar-se quase um clamor, entoa versos que rementem ao conto e também aos atributos enigmáticos da própria palavra.

Com essa análise é possível verificar que, ao se comunicar por meio de sons instrumentais, vozes e letra poética, a canção popular proporciona fruição estética gerada pelo uso da palavra em harmonia com os sons. Comunica ideias e sensações de maneira única, proporcionadas por meio de seus recursos sonoros e verbais específicos. Além disso, a canção popular no Brasil é também um importante meio de difusão da cultura e de reflexão social.

A canção popular brasileira mantém fortes vínculos com a literatura, sendo assim, tem sido fonte de estudos de diversos trabalhos de análises literárias. Quanto às artes visuais, seus 
vínculos com a literatura são menos evidentes, devido a utilizarem-se de linguagem comunicativa díspares. Enquanto na literatura e na letra da canção popular há o predomínio da comunicação verbal, nas artes visuais impera a comunicação não verbal.

No entanto, conforme será exposto mais adiante, artes visuais e literatura, historicamente, mantêm conexões de grande importância produtiva. As artes visuais, apesar de explorarem signos não verbais, também possuem capacidade de fornecerem relatos, narrativas, documentários, informações. As obras figurativas podem representar cenas de uma história real, ilustrar o clímax de uma narrativa, transmitir informações sobre pessoas, épocas e lugares. Assim, a linguagem não verbal também pode encerrar um texto, desde que lhe sejam atribuídos sentidos a partir da leitura de seus signos.

Por meio de signos visuais, é possível expressar qualquer ideia, embora sua organização e elaboração estejam sujeitas às potencialidades e aos limites da imagem. Isso significa que, assim como os códigos da linguagem verbal devem ser estudados para se compreender as mensagens verbais, os códigos da linguagem não verbal também devem ser estudados para se compreender mensagens não verbais. Entretanto, não basta conhecer determinado código para se compreender uma mensagem, pois a leitura é mais do que simples decodificação, ela requer também atribuição de sentidos.

De maneira especial as imagens devem ser estudadas, pois, embora possuam certos aspectos de fácil compreensão universal, por outro lado, também podem se constituir de símbolos e signos concebidos em contextos específicos que, por falta de informação e estudo, podem ser objeto de erro e confusão. Esse assunto, todavia, será tratado mais detalhadamente no terceiro capítulo.

Antes de se analisar as implicações sócio-educativas das imagens, é relevante averiguar quais são os recursos estéticos e os elementos utilizados pelas artes visuais para comunicar mensagens. Afinal,

\footnotetext{
sempre que alguma coisa é projetada e feita, esboçada e pintada, desenhada, rabiscada, construída, esculpida ou gesticulada, a substância visual da obra é composta a partir de uma lista básica de elementos. Não se devem confundir elementos visuais com os materiais ou o meio de expressão, a madeira ou a argila, a tinta ou o filme. Os elementos visuais constituem a substância básica daquilo que vemos, e seu número é reduzido: o ponto, a linha, a forma, a direção, o tom, a cor, a textura, a dimensão, a escala, o movimento. (DONDIS, 2003, p. 51).
}

Como recursos estéticos visuais podem-se elencar, então, os elementos e os materiais utilizados pelos artistas visuais na composição de suas obras. Cada um dos elementos visuais propiciam múltiplas possibilidades de comunicação e expressão, a depender da maneira como 
são organizados. Isoladamente ou em conjunto, reproduzem ideias, comunicam sensações, sugerem movimentos, determinam ritmos, representam sombras, luzes, formas e volumes.

O ponto é um elemento básico da comunicação visual e, embora possa parecer insignificante, sua utilização como marca gráfica e simbólica é capaz de fomentar inúmeras possibilidades criativas. Da junção de pontos formam-se as linhas e, destas, as formas. Conforme explica a autora:

Quando os pontos estão tão próximos entre si que se torna impossível identificá-los individualmente, aumenta a sensação de direção, e a cadeia de pontos se transforma em outro elemento visual distintivo: a linha. Também poderíamos definir a linha como um ponto em movimento ou a história do movimento de um ponto (ibidem, $\mathrm{p}$. $55)$.

As linhas podem ser utilizadas com diversos fins artísticos, simbólicos e decorativos. Por meio delas o artista pode expressar movimento, direção, energia. Elas definem as formas e as figuras, são usadas em esboços e desenhos para recriar a realidade ou expressar abstrações. Portanto, “a linha é o meio indispensável para tornar visível o que ainda não pode ser visto, por existir apenas na imaginação." (ibidem, p. 56).

A partir da linha é possível criar representações diversas, dar forma gráfica às ideias, seja livremente ou utilizando-se de formas padronizadas. As formas geométricas, como círculo, quadrado e triângulo permitem ao artista articular inúmeras possibilidades expressivas. Essas formas básicas são muito utilizadas na criação de ícones e símbolos, delas derivam figuras e representações abstratas da natureza, de pensamentos e sensações do artista. Também interferem na composição do tom e da direção da mensagem visual, o que contribui significativamente para criar efeitos perceptivos na obra.

Em se tratando de resultados perceptivos da obra, os estudos sobre a expressividade das cores demonstram o quanto seus efeitos são relevantes para o resultado final das produções visuais. Afinal, pelo uso das cores é possível provocar efeitos emocionais e psicológicos no espectador. Assim, as cores afetam os sentidos e podem induzir a estados emocionais suscitados pelas combinações criadas pelo artista.

Cores quentes, ou seja, derivadas do vermelho e do amarelo produzem excitação, provocam sensação de energia, causam tensão. Cores frias, derivadas do azul, proporcionam sensação de paz e conforto. Além disso, por meio das cores também é possível criar ilusão de distância e profundidade. As cores claras tendem a ampliar espaços e objetos, enquanto as cores escuras tendem a reduzi-los. Estas são algumas possibilidades de uso das cores no tocante à reação que elas podem provocar, entretanto, 
existem muitas teorias da cor. A cor, tanto da luz quanto do pigmento, tem um comportamento único, mas nosso conhecimento da cor na comunicação visual vai muito pouco além da coleta de observações de nossas reações a ela. Não há sistema unificado e definitivo de como se relacionam as matizes. (ibidem, p. 65).

Assim, às cores são atribuídos significados associativos e simbólicos, que podem estar ligados à luminosidade e ao pigmento. Afinal, a cor é um fenômeno físico que não existe de forma independente da luz. Raios luminosos refletem-se dos objetos e atingem a retina, provocando a percepção da cor. Os pigmentos (tintas e outras substâncias coloridas) funcionam como seletores de raios luminosos e, portanto, auxiliam na percepção das cores. Enfim, o artista utiliza-se da luz e do pigmento para criar efeitos diferenciados de cores e estimular sensações.

As três canoas de Guto Lacaz foram pintadas com cores que se harmonizam com seus nomes. Terra é a canoa azul, Cajuína é representada em vermelho-escuro, e Odara em amarelo. Os nomes provêm do título de outras canções de Caetano Veloso. A canção Terra menciona fotografias em que o planeta foi capturado inteiro e na cor azul. Cajuína compara a existência humana do nordestino ao fruto vermelho-escuro típico do nordeste. Finalmente, a canção Odara que exalta a paz, a alegria, também expressa na cor amarela da canoa, (cor quente e vibrante) a luz, o calor, enfim um estado de espírito que é odara. Verifica-se, então, que a obra reuniu significados verbais e não verbais numa combinação harmoniosa.

Além disso, o emprego de cores diferentes na canoa Terra é que determina a impressão forjada no espelho, de Cajuína. A visualização da terceira canoa só foi possível pela combinação das cores, das letras invertidas e da posição do espelho. As cores obedecem ainda a uma escala de cores primárias, que intensifica a vibração em Cajuína e Odara, (pintadas em cores quentes), amenizando-se em Terra (pintada de azul, cor fria).

As dimensões do espelho em relação às canoas também interferem no resultado, afinal a sua função é refletir Cajuína, logo, deve se ajustar a uma dimensão que permita a sua visualização através dele. As duas canoas são do mesmo tamanho e foram posicionadas paralelamente, sem intenção visual de movimento, a não ser pelas mudanças de reflexos no espelho. Os materiais e cores empregados na instalação são lisos, sem sugestões de texturas.

Entretanto, textura, dimensão, escala e movimento podem ser forjados visualmente pelo uso de pontos, linhas e cores. Logo, ao produzir uma obra bidimensional como o desenho e a pintura, por exemplo, o artista visual consegue criar efeitos que formam a ilusão destes elementos. Obras tridimensionais como escultura e arquitetura, por sua vez, buscam os mais diversos efeitos expressivos ao destacar cada um desses elementos de maneira apropriada. 
Dessa forma, seja criando a ilusão da textura, da dimensão, de escalas e de movimentos, ou pela maneira como esses elementos são realmente trabalhados, a expressividade visual que eles propiciam faz grande diferença na composição da obra.

Por meio das técnicas de utilização dos elementos da linguagem visual, o artista elabora imagens que podem expressar ideias, pensamentos, sensações ou comunicar mensagens. Conforme afirmou Joly (2007, p. 61): “quer ela seja expressiva ou comunicativa, podemos admitir que uma imagem constitui sempre uma mensagem para o outro, mesmo quando este outro é o próprio autor da mensagem." Portanto, imagens podem auxiliar a aproximação entre o Eu e o Outro, utilizando formas não verbais de comunicação.

Conquanto o Outro de quem se pretende aproximar pode ter distintos rostos, inúmeras também são as formas com que a arte intenta a aproximação. Por isso, cada arte, em sua singularidade, traz oculta a face daquele que a produziu. Os elementos visuais, trabalhados de maneira particular por cada artista, produzem no espectador os efeitos que são próprios da linguagem visual. Então, os estímulos visuais produzidos pela imagem revelam que

\begin{abstract}
os instrumentos plásticos da imagem, qualquer que ela seja, mesmo os próprios instrumentos das artes plásticas, fazem dela um meio de comunicação que solicita a fruição estética e o tipo de recepção que a ela está ligada. O que significa que comunicar pela imagem (mais do que pela linguagem) vai necessariamente estimular o espectador a um tipo de expectativa específico e diverso daquele que uma mensagem verbal estimula. (ibidem, p. 68).
\end{abstract}

Imagens são capazes de provocar sensações estéticas imediatas, e a contemplação visual de uma imagem ocorre de maneira bastante distinta daquela que se faz de um poema, por exemplo. A recepção de uma imagem está ligada aos elementos visuais que foram utilizados em sua produção. Assim, obras compostas por texturas proporcionam sensações táteis, enquanto obras compostas por cores claras e planas proporcionam sensação de monotonia. A recepção depende ainda do tipo de expectativa que o observador conserva a respeito da composição.

O cinema está contado entre as artes que se utilizam de imagens concretas em sua composição. O filme A terceira margem do rio, de 1994, dirigido por Nelson Pereira dos Santos, não figura entre as obras analisadas neste estudo por dois principais motivos:

a) Não se trata exatamente de produção cinematográfica baseada no conto A terceira margem do rio, mas de uma fusão de cinco contos de Guimarães Rosa publicados no livro Primeiras estórias (2001). Além do título, algumas cenas referem-se ao conto em questão, porém não é o principal argumento do filme. 
b) A proposta deste estudo é analisar a transposição de obras de linguagem verbal para obras de linguagem não verbal. Uma produção cinematográfica se compõe de uma multiplicidade artística, utiliza diferentes recursos visuais, verbais e sonoros e, além disso, possui atributos específicos da linguagem cênica e cinematográfica.

O filme A terceira margem do rio será mencionado brevemente neste estudo por se tratar de obra que tem ligações com seu objeto, porém sem maiores aprofundamentos investigativos, uma vez que a produção cinematográfica comporta especificidades relevantes que, contudo, distanciam-se dos objetivos aqui propostos.

O cinema é uma arte que se utiliza de muitos recursos estéticos provenientes de outras linguagens artísticas, em especial aqueles das artes visuais, entretanto há alguns procedimentos que são exclusivos da linguagem cinematográfica. Ademais, devem-se considerar, numa produção cinematográfica, os diferentes modos de representação da realidade e também da imaginação criadora do artista. Entretanto, segundo Sganzerla:

\footnotetext{
Os verdadeiros cineastas, dos quais depende o futuro do cinema, não têm visões. Não elaboram ou expressam seus mundos exclusivos. Arriscam-se a ver as coisas como elas são, de frente: olham, captam, filmam coisas em contínua evolução e na terceira pessoa do presente do indicativo - correndo riscos. E pensam diretamente em ângulos, panorâmicas, plano-sequências. (idem, 2001, p. 67).
}

Há sempre uma atitude estética por trás da produção de toda obra artística. Embora a seleção dos modos de representação esteja sujeita aos comandos do produtor, a ele cabe expressar não somente os seus devaneios e caprichos. Afinal, como detentor das lentes pelas quais é possível refletir e mostrar o mundo torna-se também comprometido com esse mundo e com a forma como ele será visto por outros.

Assim, ao produtor cabem as escolhas que determinarão a receptividade da obra em determinados contextos. Apesar de não ser possível apreender a realidade, a câmera focaliza e insinua uma realidade. Por isso deve-se considerar que o cinema está sujeito também à "relatividade da câmera: qualquer cena pode ser tratada de inúmeros ângulos, distâncias, estilos diferentes. A eleição de determinado ângulo define uma escolha por parte do diretor sendo a origem de toda a mise-em-scène" (ibidem, p. 98).

Mas a visão humana é ilusória e, ademais, escolher um ângulo impõe renunciar a outro. Além disso, sendo o cinema uma arte temporal, a manipulação do tempo, da duração do foco, influencia os modos como são percebidos os elementos captados pela câmera. Então, por meio da manipulação do tempo, é possível influenciar opiniões, estimular pensamentos, proporcionar sensações. 
Indissociável do tempo, o espaço no cinema é construído por meio de inúmeras técnicas que conduzem ao seu domínio, no intuito de atender às pretensões ideológicas e estéticas dos produtores. $\mathrm{O}$ espaço no cinema revela mais do que um quadro, um cenário. Ele se adéqua ao conteúdo do filme, agregando significações simbólicas, dramáticas, psicológicas.

Os planos com que são focalizados os elementos interferem na percepção das ideias, podem conduzir a diferentes modos de compreensão da mensagem. Os destaques em primeiro plano também servem para direcionar a atenção do espectador, desviando-a de certos elementos, favorecendo ou prejudicando uns em relação a outros. Afinal, elementos focalizados em primeiro plano são percebidos com destaque, neles se concentram o interesse do espectador.

Recursos sonoros também são amplamente utilizados no cinema a fim de se obter efeitos surpreendentes. A sonoplastia, assim como a trilha sonora de um filme, propicia uma atmosfera carregada de significados. A música pode criar efeitos psicológicos, dramáticos, cômicos. Os diálogos, proferidos simultaneamente com a imagem, fazem aumentar a ilusão de realidade das cenas. Enfim, as combinações de som e imagem fazem do cinema uma arte de múltiplas possibilidades estéticas e comunicativas.

As fragmentações de imagens e a incorporação de sons são todos finalmente ajustados por meio da montagem. Ou seja, os cortes e as emendas das diversas partes filmadas são organizados a fim de se obter a ordem, a sequência e o ritmo da narrativa. Segundo Aumont (2004, p. 168): “mas o cinema, ou melhor, o filme, é também a reunião de vários desses blocos (os planos), 'em certas condições de ordem e de duração', expressão que se reconhece a definição de montagem [...]" E, conforme Betton (1987, p. 71): “é o elemento mais específico da linguagem cinematográfica".

Por meio de todos esses recursos estéticos e comunicativos de que a atividade cinematográfica dispõe, ocorrem identificações e reflexões da realidade. O espectador interpreta as cenas e com elas estabelece associações. Entretanto,

\footnotetext{
devido à ilusão mesma da visão humana, nasceu a câmera e antecessores do cinema, arte temporal, e no cinema a duração. Baseia-se no falso, nada mais - como a vida mesma - na ilusão, matéria, nada mais. Nesse universo em representação, a arte ocorre a seu duplo e o autor em busca do "outro". O que é o duplo ou o outro? (SGANZERLA, 2001, p. 69).
}

Ao duplicar a realidade em movimento, ao criar a ilusão de retenção do tempo, o cinema, como as outras artes, baseia-se numa espécie de simulacro, no falseamento do mundo 
e das coisas. Embora o autor deva comprometer-se com o Outro, aborda-o sempre conforme um ponto de vista. O duplo e o Outro se mostram ilusórios, mas é desta ilusão que vive a arte e, a partir dela, a sociedade se mostra, se vê e se questiona. Contudo, "o cinema permite que cada espectador conte-se a si próprio, veja-se viver, julgue-se. Revela-nos inúmeros desejos insuspeitos.” (BETTON, 1987, p.98).

As emoções potencialmente vivas que se apresentam na tela do cinema, por serem inerentes à condição humana, conseguem tocar o espectador, não apenas naquilo que ele tem de mais íntimo, mas também em relação aos sentimentos dos outros. Assim, pertencentes todos a uma mesma humanidade, a arte estabelece entre as pessoas uma ponte, considerandose que

\footnotetext{
todo homem se angustia com a ideia da solidão, do desconhecido, da morte - de sua morte - e sente uma necessidade constante de ser amado e de se sentir existindo, vivendo. Ele projeta sobre os outros seus próprios pensamentos, suas emoções, seus sentimentos, e o contato direto (ou imaginário) com seus semelhantes tranquiliza-o certificando-o de sua existência real. Ver e escutar os outros, finalmente, é escutar-se e ver-se. (ibidem, p.99).
}

Enfim, o cinema e também as outras formas de arte, cada uma por suas diferenças e semelhanças, mas, sobretudo por suas singularidades, conduzem o ser humano ao encontro de si mesmo e também dos outros. Uma vez que cada ser é singular e complexo, assim também são as formas artísticas criadas com o intuito de dar conta, cada uma a seu modo, do universo humano.

As artes formam um patrimônio cultural da humanidade e disponibilizam aos espectadores conteúdos que podem fomentar novas produções. Dessa forma, a literatura frequentemente fornece inspiração às produções cinematográficas. Entretanto, por se tratarem de linguagens que se utilizam, sobretudo, de códigos díspares como são o visual e o verbal, as expectativas de fidelidade à obra original são, geralmente, frustradas. Isso ocorre porque "não se pode representar visualmente significados verbais, da mesma forma que é praticamente impossível exprimir com palavras o que está expresso em linhas, formas e cores.” (ibidem, p. 116).

O filme de Nelson Pereira dos Santos é interessante por conseguir reunir cinco contos do livro Primeiras estórias, formando uma narrativa única que, embora não se fidelize a nenhum deles, traz o essencial de cada um. A adaptação para a linguagem cinematográfica, onde o tempo é limitado e as imagens são concretas (independentes da imaginação do espectador), contempla os cinco contos e cria uma trama em que as estórias se completam. 
O trabalho de transposição de linguagens artísticas se sujeita às imposições dos elementos com os quais é elaborado. Antes de buscar fidedignidade à obra original, propõe um novo olhar sobre a obra, acorrendo às acomodações exigidas pelos recursos estéticos de cada linguagem e também pelas impressões pessoais do produtor. As expectativas de fidelidade à obra literária nas transposições para o cinema geralmente são maiores, pelo fato de ele utilizar-se de elementos verbais e não verbais, entretanto,

na maioria dos casos, a transposição para o cinema é uma re-criação: o tradutor além da escolha fundamental que se lhe impõe - realiza uma obra pessoal e manifesta-se não como "ilustrador", mas como um verdadeiro criador: inspira-se numa obra literária - todo artista extrai sua argila, sua matéria bruta, do patrimônio cultural. Mas sem a preocupação de continuar fiel à letra ou ao espírito, repensa totalmente seu tema para lhe conferir uma visão inteiramente pessoal, às vezes completamente diferente da do romancista. (BETTON, 1987, p. 118-119).

As transposições não devem, portanto, ser encaradas como mera ilustração da obra literária. Aliás, as boas ilustrações costumam fazer mais do que repetir em imagens o que já foi dito em palavras. Claro que existem boas e más adaptações, mas tal julgamento não deve ter como critério fundamental a correspondência fiel à obra original. Averiguar de que forma foram resolvidas certas questões estéticas e a engenhosidade com que certos elementos foram acomodados em linguagem cinematográfica (em planos, roteiros, movimentos, ângulos sequências) mostra-se bem mais apropriado.

Enquanto o cinema manipula imagens bidimensionais em movimento, escultura, arquitetura e, entre as vanguardas, a instalação artística, compõem-se, sobretudo de imagens tridimensionais estáticas. As imagens bidimensionais podem insinuar a terceira dimensão pelo uso de técnicas específicas, assim como as imagens estáticas insinuam movimento pela maneira como suas formas se direcionam no espaço.

As artes que produzem imagens estáticas, ao insinuar uma narrativa ou um discurso, precisam selecionar e paralisar o instante. Ou seja, ao artista cabe ressaltar um momento e aprisioná-lo nas formas de sua arte, como na famosa escultura do artista renascentista Michelangelo, que retrata o herói bíblico Davi. Outras esculturas foram construídas para retratar o herói, entretanto, Michelangelo foi considerado inovador, não somente pelo impressionante realismo anatômico da obra, mas também pela escolha do momento a ser retratado. Enquanto outros artistas como Donatello e Verrochio optaram por retratar o herói após a vitória contra o gigante Golias, Michelangelo optou pelo momento imediatamente anterior à batalha. E logrou infundir na obra as inquietações do espírito humano diante da tomada de uma decisão difícil. A obra, em vez de apresentar o Davi vitorioso após o combate, 
apresenta-o entre a postura firme de quem tomou uma decisão consciente e a tensão corporal (observadas nas veias sobressaltadas e nos olhos expressivos), de quem se prepara para lutar contra um inimigo mais forte.

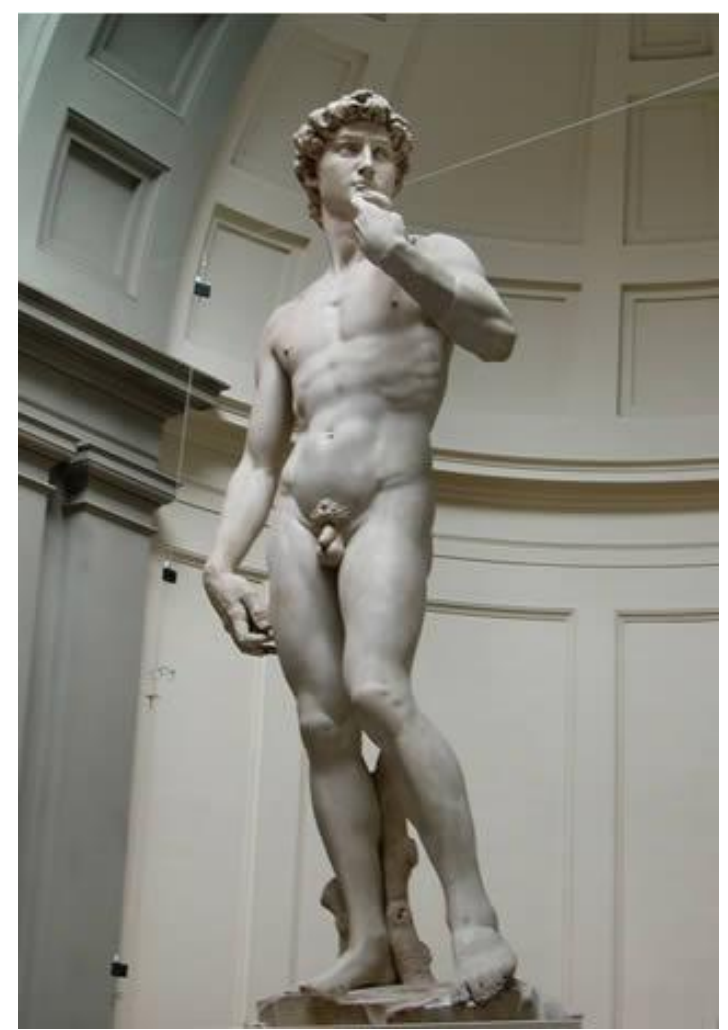

Fig. 03 - Davi, de Michelangelo.

Dentro de seus limites temporais, as artes que elaboram imagens estáticas, podem se prevalecer da complexidade e da intensidade que um pequeno instante pode vir a comportar. A instalação artística tem se demonstrado como uma arte efêmera que, portanto, privilegia o instante à perenidade. Não obstante, por se tratar de obra interativa, uma instalação pode sugerir diferentes momentos, conforme a apreciação do espectador.

A instalação de Guto Lacaz, ao expor as duas canoas vazias e pela sutileza do uso do espelho, proporciona ao espectador vivenciar diferentes momentos do conto, muito embora as imagens tridimensionais da instalação permaneçam fixas. Assim, se o espectador decide entrar em uma das canoas, assume a personificação do canoeiro; se resolve apenas apreciar à distância, assume a personificação do filho. Em se tratando de mímesis, no entanto, tais identificações são intercambiáveis. Dessa feita, o espectador pode decidir personificar o filho que assume o lugar do pai na canoa, ou do pai antes de entrar nela, ou, ainda, elaborar outras 
situações que possam ser mimetizadas, como por exemplo, um retorno do pai à primeira margem.

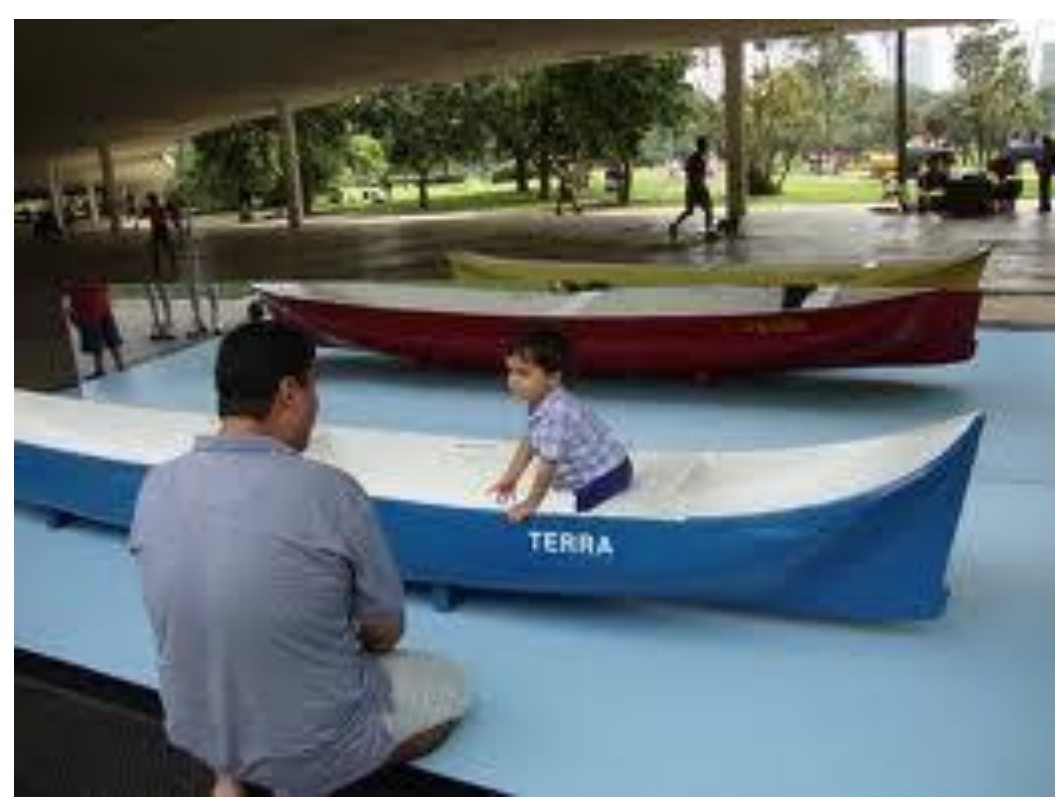

Fig. 4 - Participação do público à exposição no Parque Ibirapuera (2010)

Cada linguagem artística provoca estímulos sensoriais e reflexões estéticas conforme utilização e combinação de seus meios expressivos. Ao utilizar-se de uma obra de linguagem verbal para produção de outra obra de linguagem não verbal, o artista realiza uma tradução intersemiótica, pois terá de comunicar a mesma ideia por meio de signos e de elementos expressivos diferentes.

Além disso, a tradução intersemiótica de uma obra de linguagem verbal em obra de linguagem não verbal pressupõe, antes, percepção e interpretação da obra original para a formação de um "juízo perceptivo". Logo, "representar esses objetos de forma tangível, no entanto, pressupõe a tradução dos "juízos perceptivos" dentro dos limites e potencialidades de um determinado meio e uma determinada linguagem." (PLAZA, 2000, p. 48).

Toda manifestação artística é constituída de forma e conteúdo. As obras analisadas aqui apresentaram um mesmo conteúdo de forma diferente, cada uma se valendo de seus recursos estéticos a fim de tornar o conteúdo significativo em sua linguagem. É importante ressaltar que todo conteúdo pode ser apresentado das mais diferentes formas e linguagens, estando sujeito, no entanto, às acomodações exigidas pela singularidade de cada linguagem.

Sendo assim, as transposições do conto A terceira margem do rio às outras linguagens artísticas não visam a uma simples repetição do conteúdo exposto primeiramente por Guimarães Rosa. A canção visa transcrever em linguagem musical, por meio da composição, 
do ritmo, da melodia, um pouco do que Rosa apresentou em linguagem escrita. A instalação artística, por meio da organização e exposição de imagens concretas, visa aproximar ludicamente o espectador da atmosfera mística do conto. Assim, cada linguagem oferece uma nova forma de se ver e apreciar determinados aspectos do conto.

\subsection{Prosa, poema e letra poética: diferenças e semelhanças}

Haja vista a singularidade artística de cada linguagem e os aspectos mais marcantes com que cada uma apresentou o tema em questão, é importante entender ainda as diferenças e semelhanças entre prosa, poema e letra poética. Seguem-se, portanto, algumas considerações acerca do assunto, que nortearão as análises das obras.

O texto poético, seja ele poema ou letra de canção, utiliza-se da linguagem escrita como recurso estético para comunicar ideias e significados. Dessa forma, ele instiga a imaginação, por meio da palavra. Uma característica marcante do texto poético, e que o distingue da prosa, é a versificação. Ou seja, ainda que se perceba a linguagem poética na prosa - pelo uso de metáforas e tratamento mais subjetivo do tema - se não for escrita em versos, não deverá ser considerada poema. Dessa maneira, a linguagem poética caracteriza a poesia, que pode estar presente em textos não poéticos como a prosa. O que caracteriza o texto poético é a escrita em versos, como ocorre no poema e nas letras da canção popular.

Canção e poema apresentam sonoridade, porém de forma distinta. Na composição do poema encontram-se intrínsecos a sonoridade e o ritmo, sem que para isso ele tenha de ser musicado. Já a letra de uma canção, solicita música, nela é que se completa a sua sonoridade, ou seja, a letra exige complemento musical. Algumas letras de música são comparáveis a poemas, mas de modo geral, a letra se submete à música, o que não ocorre ao poema. $\mathrm{Na}$ maior parte dos casos, as notas e arranjos musicais de uma canção é que comandam o ritmo, enquanto à letra, reserva-se a função de comunicar mensagens. As imagens evocadas pela canção são o resultado da sua composição híbrida, com letra poética e arranjo musical.

Diferentemente, o poema assume como um todo a construção de significados, por meio da mensagem, do ritmo, dos sons, enfim, em sua composição estética estão previstos tanto os elementos necessários à comunicação de mensagens, quanto os elementos linguísticos que determinam seu ritmo e sua sonoridade. Portanto, o sentido de um poema é construído, esteticamente, de forma completa em si mesmo, enquanto a letra da canção une-se aos elementos musicais para juntos formarem sentido. As imagens provocadas pelo poema são construídas pelo uso das palavras e pela disposição delas no espaço. 
Embora persistam ainda preconceitos e polêmicas em torno do estudo da canção popular no meio intelectual e acadêmico, é inegável a importância do cancionista na construção da identidade cultural brasileira. Por meio das semelhanças e diferenças de linguagem estética, a canção deve ocupar o seu lugar, não apenas como mercadoria cultural, mas, sobretudo, como expressão do imaginário social. E essa expressão é formada pelo texto poético, conjuntamente com a melodia. Não obstante, ocorrendo ou não mudanças significativas de sentido, quando analisados em separado, texto poético e melodia não se esvaziam completamente pela separação. Segundo Cyntrão:

Quando se propõe a análise literária do texto da canção, o que se busca é desvendar a sua textualidade, ou seja, os sentidos do discurso que se explicitam na sua espessura linguística e histórica, a relação codificada entre ideologia e inconsciente. (idem, 2004, p. 120).

A textualidade da letra da canção é uma realidade cultural que, no Brasil, ganhou força a partir do Modernismo. Em seus estudos sobre o texto poético, Cyntrão considerou que "a canção popular urbana constitui uma etapa de manifestação do Modernismo brasileiro." (ibidem, p. 122). Historicamente, portanto, as letras poéticas brasileiras, foram alcançando valor estético e expressivo similar aos dos poemas modernistas. Sensível aos percursos históricos da arte, o crítico literário vem apresentando propostas a este fenômeno, seja por meio da receptividade, seja impondo resistência.

Quanto a este estudo, que destaca as produções interartes, propõe-se a investigar, na textualidade da letra da canção de Caetano Veloso, a forma como a canção se vale de seus recursos estéticos para evocar imagens e comunicar a ideia apresentada pelo texto literário. Nesse intuito, não se pretende excluir da letra a melodia, pois que ambas são imprescindíveis à totalidade estética da canção. Isto não significa, porém, que a letra não possa ser tratada isoladamente, quando se faz necessário abordar certas especificidades do texto e da linguagem verbal. A esse respeito, Cyntrão destaca:

É preciso deixar claro que fazer investigações literárias das letras de canções, bem como de adaptações fílmicas de textos literários, obriga a certas acomodações dentro das perspectivas analíticas, já que as estruturas estéticas próprias da melodia ou do filme intervêm de forma substantiva no produto final. (ibidem, p. 121).

Dessa forma, às vezes em separado, às vezes em conjunto com a melodia, a canção poderá sofrer, em sua análise, as acomodações necessárias ao objetivo proposto. Além disso, não se pretende, com este estudo, formular julgamentos de valores estéticos da canção ou das 
outras formas de arte, mas, sobretudo, verificar como os diferentes recursos estéticos contemporâneos, na prosa, no texto poético e na instalação artística invocam e comunicam a alteridade, fomentando produções expressivas que se formam a partir da perspectiva do Outro. E esse outro é também o receptor da obra, aquele que a recebe, a acomoda e a transforma em imagem material ou não material.

Segundo Cyntrão: "a literatura sem contatos, contágios e contaminações não existiria como produto da alma humana, uma vez que o próprio ser é o não-ser e é a um tempo o que todos somos." (ibidem, p. 119). O mesmo se dá com as outras artes, e isso favorece o fenômeno das conexões artísticas. Na contemporaneidade não é diferente, ao contrário, as artes encontram-se, atualmente, cada vez mais entrelaçadas.

\subsection{Definições e considerações sobre instalação artística}

A instalação artística se apresenta como uma forma de expressão altamente propícia aos inter-relacionamentos das artes. Entretanto, ao se analisar a arte contemporânea, esbarrase nas dificuldades próprias de uma manifestação em desenvolvimento. A instalação artística, assim como outras expressões da arte contemporânea, vão sendo consolidadas com o tempo e, portanto, somente ao longo dos anos é que se definirá com precisão sua importância histórica e seu valor estético. Como já foi mencionado, este estudo não pretende formular juízo de valor sobre as expressões artísticas, objetos desta análise. Importa, no entanto, orientar o leitor acerca do surgimento e relevância da instalação artística na arte contemporânea e, enfim, ao estudo interartes aqui proposto.

Após a Semana de Arte Moderna de 1922, houve grande ampliação dos horizontes artísticos no Brasil, possibilitando o surgimento de diferentes manifestações, uma vez que os artistas passaram a buscar maior liberdade de expressão. Os princípios acadêmicos foram sendo deixados de lado e novas propostas técnicas de elaboração da obra de arte foram surgindo.

Então, a partir da década de 1960, as criações artísticas se dividiram em muitas tendências que, geralmente, ultrapassam os limites das artes plásticas e mesclam outras formas de expressões. A arte contemporânea busca extrapolar todos os limites à criação artística, o que, de forma positiva, enseja uma diversidade de produções, mas que, por outro lado, dificulta as definições de parâmetros minimamente plausíveis sobre a qualidade dessas criações. 
A fim de se organizar uma classificação estética dessas propostas, elas foram sendo nomeadas conforme sua estrutura de realização, como, por exemplo, Arte conceitual, Arte processual, Arte pobre, Body art, Land art, Minimalismo. Como desdobramento dessas propostas estão as artes que se realizam em interação com o espaço e que foram chamadas de environment (ambiental) e assemblage, conforme a dimensão e a forma como ocorre essa interação. Ressalte-se que

tanto "ambiental" quanto "instalação" são rótulos que se tornaram correntes desde os anos 70 para dar conta da crescente frequência com que os espectadores achavam que precisavam estar na obra para poder vê-la e vivenciá-la. (ACHER, 2001, p. 103).

A instalação artística é, como se pode observar, uma das muitas tendências da arte contemporânea, que vem se consolidando no cenário nacional. Trata-se de ocupar um determinado espaço, como uma sala, em ambiente fechado, ou mesmo amplos espaços públicos, com exposições que procuram chamar a atenção para um tema ou ideia. Os elementos expostos variam em número e forma, podendo contemplar desde um único elemento que ocupa todo o ambiente, a diversos, do mesmo tipo, ou de tipos diferentes. Podese utilizar, então, não somente da linguagem visual, mas também de outras linguagens expressivas, como a música, o vídeo, o som, a palavra. Conforme estudos do artista Percival Tirapeli:

\footnotetext{
A instalação passa a utilizar vários recursos, como o espaço, que era só da escultura, ou das paredes, que antes eram apenas suporte para a tela, música e projeção de imagens. Assim, percebe-se que as divisões tradicionais das artes segundo as técnicas empregadas já não valiam mais, e o artista podia se expressar de várias maneiras. (idem, 2006, p. 52).
}

Os recursos estéticos da instalação artística, portanto, são indefinidos, pois até mesmo objetos do cotidiano podem servir à elaboração da obra. Conforme Santana (2003, p. 44): "mais do que retratar, o artista coleciona, cata símbolos do cotidiano e agrupa isto sobre um suporte. É uma crítica da ideologia, um retrato industrial do tempo". Mas a instalação artística também atua na imaginação do receptor ao proporcionar experiências sensoriais. As imagens que ela evoca são o resultado dessas experiências e, dessa forma, costumam suplantar o figurativismo. No entanto, ao se realizar por meio da experiência sensorial, ela é também uma arte efêmera, capaz de induzir à formação de imagens mentais complexas, porém muito restritas à duração da experiência. 
Quanto ao espaço, podem-se encontrar instalações em diversos ambientes, apropriados, como museus, ou não tão apropriados, como os espaços públicos. Quanto a esse aspecto da arte contemporânea, observa-se que

\footnotetext{
o mundo ficou pequeno e a arte, maior. Ao alcance de todos, pois as instituições culturais e os museus sabem da importância da arte na comunicação e na psicologia humanas. Este momento lúdico do objeto e suas possibilidades demonstra avanços na sociabilidade e na humanização dos homens. Para que serve a arte? Para ter um diálogo diferente entre diferentes mentes. (TIRAPELI, 2006, p. 52).
}

A instalação artística traz para o campo das artes, uma proposta multimídia e interativa. Tem-se demonstrado como uma arte que exige a participação do público, promovendo, como destacou Tirapeli, mais sociabilidade e humanização das pessoas. $\mathrm{O}$ diálogo que ela procura estabelecer com o espectador é marcado pela diferença, não apenas de linguagens, mas também de pensamentos, ideias e significações. "A obra não era algo somente para se olhar, mas um espaço a ser adentrado e experimentado de um modo físico pleno." (ACHER, 2001, p. 106).

A instalação de Guto Lacaz, durante os dias em que esteve exposta na marquise do Parque Ibirapuera em São Paulo, em março de 2010, permitiu aos espectadores mais do que olhar. Devido à dimensão e solidez do projeto, comportou a possibilidade de se entrar nas canoas e confrontar-se com o espelho e as reflexões que esse gesto tende a desencadear.

As obras que compõem este estudo, o conto, a canção e a instalação artística, suscitam inúmeras questões concernentes à alteridade. Em prosa, em versos ou em imagens, as artes expressam e expõem a pessoa humana, seus sentimentos, seus enigmas, seus conflitos. Por cada uma dessas linguagens artísticas é possível observar e refletir como arte e literatura impulsionam o sujeito a um movimento infinito em direção ao Outro. Afinal, sobre quem falam as obras? A quem elas se dirigem? Quem as produz? Todas as respostas podem ser "o/ao Outro". 


\section{Segunda margem: o Outro}

"Há muito tempo, pois,

há muito tempo, pode-se dizer que o animal nos olha?

Que animal? O outro."

"Se olhares nos olhos de um cavalo, verás muito da tristeza do mundo!"

Em sua busca por afirmação de identidade e autodeterminação, o sujeito irá, consequentemente, confrontar-se com o Outro. Entretanto, quem é o Outro? O Outro é tudo o que não sou, ou seja, o diferente, o estranho ao Eu. Muitas vezes, o diferente causa perturbações ao Eu, pois a sua existência se interpõe entre o que Sou, e coloca em questão a "minha" legitimidade de Ser. Ou seja, o Outro é aquele que traz impedimentos, objeções, questionamentos quanto ao que Eu Sou. Na solução desse impasse, o sujeito tende à negação do Outro, numa tentativa de, anulando assim a existência do Outro, afirmar a sua.

Portanto, cotidianamente em suas relações com os outros, o sujeito pode assumir uma postura rígida de negação das diferenças e até mesmo de tentar reprimi-las, por meio da imposição de padrões. A não aceitação do Outro termina num conflito em que alguém ou um grupo exerce opressão sobre outro.

$\mathrm{O}$ Eu que habita a primeira margem intenta invadir a segunda e transformá-la. Em sua relação com o Outro o Eu não consegue simplesmente deixar o Outro ser. A razão disso, é que o Outro é visto como distante, diferente e, assim, um não ser que deve ser descoberto, dominado, controlado. Muitas vezes a dominação do Outro perpassa a formulação e difusão de discursos.

Ali, então, na primeira margem do rio, encontra-se a mesmidade: os sujeitos que se assemelham todos e se refletem um no outro como numa imensa sala de espelhos. $\mathrm{O}$ Eu que se fixou na primeira margem espera exatamente isso de todos os outros, que permaneçam fixos, que não esbocem nenhuma tentativa de ruptura, que ajam sempre como se não houvesse uma segunda margem.

Entretanto, apesar da segurança de se permanecer fixo à primeira margem, de se manter em comunhão total com a mesmidade, existe a presença constante e perturbadora da segunda margem do rio com todos os seus atrativos e mistérios. E ela ali já se encontrava antes de se terem estabelecido a mesmidade da primeira margem, aliás, é justamente porque ela existe que $\mathrm{O}$ Eu pode tomar consciência da sua própria existência. Enfim, o indivíduo,

\footnotetext{
${ }^{4}$ Jacques Derrida, 2002, p. 15

5 João Guimarães Rosa, em entrevista a Günter Lorenz - "Diálogo com Guimarães Rosa".
} 
apesar de se conformar em ser o Mesmo, sabe que também pode existir no Outro absoluto que habita a segunda margem do rio.

Finalmente, o sujeito que se encontrava fixo à primeira margem, intenta ir de encontro à segunda. Em outras palavras, o sujeito reage aos apelos do Outro e se posiciona de maneira responsável e ética frente a sua exterioridade. Mas, conforme Ricoeur (1991, p. 394), a interioridade não pode representar uma total reclusão em si, nem uma total separação entre o ego e o alter, afinal, o Eu pode tornar-se apto ao acolhimento e ao reconhecimento do Outro, por meio da reflexão.

O sujeito se vê refletido no Outro, ele se reconhece e se identifica com as narrativas que encontra. A formação de sua identidade vai se configurando ao longo do tempo a partir de histórias fictícias e reais, as quais influenciam a produção da narrativa de si. No entanto, verse refletido no Outro não significa deparar-se com o olhar do Outro sobre si.

Em seu livro $O$ animal que logo sou (a seguir), Jacques Derrida aborda a questão de perceber-se visto (e visto nu) pelo olhar de um animal, e a perturbação que isso lhe causa. $\mathrm{O}$ autor discorre sobre a estranheza, o incômodo, a vergonha que sente ao se deparar nu diante do olhar de um gato. Além disso, sente vergonha de sentir vergonha, pois isso lhe parece injustificável, uma vez que se encontra nu diante de outro animal também nu. Entretanto, ao contrário do ser humano, o animal não sabe que está nu e, portanto, é como se não estivesse.

Por meio desse texto, que é decorrente de uma aula conferência proferida por ele em 1997 em Cerisy, na França, Derrida sugere considerações sobre as relações entre o ser humano e os animais, mas ainda abre espaço para averiguações quanto ao relacionamento do sujeito com o Outro. Aliás, uma característica do autor é justamente a abertura do texto aos sentidos e conclusões aos quais o leitor possa chegar a partir das provocações suscitadas pela leitura e por suas reflexões. O que se questiona aqui é, enfim, a presença do olhar do outro sobre o sujeito e a constatação consciente desse olhar.

O próprio título já sugere as inferências que o texto reporta ao ser humano, pois em contrapartida ao penso, logo existo de Descartes, Derrida apresenta o animal que logo sou, acrescentando à discussão um ponto de vista em que o sujeito se depara com uma situação que o leva a perceber-se não como determinante, mas como alguém que está, ainda que a sua revelia, submetido ao olhar de um outro ser.

Que há uma segunda margem, todos sabem, no entanto, alguns não a levam em consideração; alguns pairam sobre ela o seu olhar e tecem-lhe definições. Outros, porém percebem-se vistos por ela. E não há como deixar de se surpreender ao deparar-se visto a partir da segunda margem, principalmente quando se é apanhado nu, por olhos longínquos, os 
quais nunca antes se imaginou pudessem ser dirigidos à primeira margem onde se encontra $\mathrm{o}$ sujeito.

O animal ao qual Derrida se refere, uma gata, que o surpreende nu e o observa antes mesmo que ele tenha se percebido nu, pode ser também o ser humano excluído, diferente, distante, aquele que em nada se assemelha ao que eu sou, ou seja, o Outro. Sobre ele têm-se debruçado os filósofos, sociólogos, psicólogos. Alguns buscam investigá-lo em sua nudez e, como Adão no Gêneses, atribuem-lhe nomes e definições. Não raro ocorre de imputarem-lhe determinações, ou imporem sobre ele alguma autoridade. Enfim, Derrida constata que

\begin{abstract}
haveria, em primeiro lugar os textos assinados por pessoas que sem dúvida viram, observaram, analisaram, refletiram o animal, mas nunca se viram vistas pelo animal; jamais cruzaram o olhar de um animal pousado sobre elas (para não dizer sobre sua nudez); mas mesmo que se tenham visto vistas, um dia, furtivamente, pelo animal, elas absolutamente não o levaram em consideração (temática, teórica, filosófica); não puderam ou quiseram tirar nenhuma consequência sistemática do fato que um animal pudesse, encarando-as, olhá-las, vestidas ou nuas, e, em uma palavra, sem palavras dirigir-se a elas; absolutamente não tomaram em consideração o fato que o que chamam animal pudesse olhá-las e dirigir-se a elas de baixo, com base em uma origem completamente outra. (idem, 2002, p. 32).
\end{abstract}

Portanto, quem, ao se perceber visto nu ou vestido, por um animal, foi capaz de acolher esse olhar, apesar de não poder se reconhecer, ou se identificar com ele? E, por outro lado, quem é capaz de olhar o Outro com o olhar infinito de um animal que, desprovido de linguagem, perdeu o poder de nomear?

O não poder ou não querer nomear, de modo algum impede que se seja nomeado, ocasionando, então um impasse, o de ser determinado por outrem sem que seja levada em consideração a sua autodeterminação. Isso não significa que somente por meio da linguagem verbal seja possível formular determinações, mas que ela é o meio mais eficaz para este fim e fator determinante que diferencia o ser humano dos outros animais. Conforme Derrida: "o único e indivisível limite que separaria o homem do animal, a saber, a palavra, a linguagem nominal da palavra, a voz que nomeia, e quem nomeia a coisa enquanto tal". (ibidem, p.88).

Sobre "Nosso pai" muito se discursou: "as vozes das notícias se dando pelas certas pessoas - passadores, moradores das beiras, até do afastado da outra banda, descrevendo que nosso pai nunca se surgia tomar terra, em ponto nem canto, de dia nem de noite, da forma como cursava o rio, solto solitariamente". (Rosa, 2001, p. 81). De uma margem a outra do rio falava-se nele e, com certeza que também o nomeavam. Ele, entretanto, emudeceu: "E nunca falou mais palavra, com pessoa alguma. Nós também não falávamos nele. Só se pensava”. (ibidem, p. 82). 
A família de "Nosso pai" decidiu-se por calar-se a seu respeito, propuseram-se um não querer nomear. Em consideração a "Nosso pai”, por sua opinião em manter-se calado, a mãe e os filhos privaram-se do discurso sobre ele, pois "ao se encontrar privado de linguagem, perde-se o poder de nomear, de si nomear, em verdade de responder em seu nome. (como se o homem não recebesse também seu nome e seus nomes!)" (DERRIDA, 2002, p. 41). A família se eximiu da responsabilidade de nomear "Nosso pai", de apresentar sobre ele qualquer discurso, uma vez que o acontecimento era demasiado estranho para ser contido em palavras. Já idoso, o filho tentar construir o relato, mas percebe-se como "homem de tristes palavras." (op. cit., p. 84 et. seq.). "Nosso pai" fazia-se ausência, não emitia as respostas de que o filho necessitava para compor a narrativa.

Entretanto, o que é responder? E o que é necessário ao Eu para que compreenda ou acolha a resposta do Outro, mesmo a desse Outro desprovido de linguagem? A alteridade não é passível de ser encerrada nas limitações do discurso. Ao contrário, a cada vez que se tecem discursos sobre o Outro, há, de alguma forma, a violação da sua alteridade. $\mathrm{O}$ discurso normalmente é feito pelos que viram o animal. Mas quase nunca pelos que se viram vistos por ele.

O animal não fala por si, por meio da linguagem. A linguagem é o que une, mas também separa os seres. Estar desprovido de linguagem é semelhante a estar nu, mas, conforme já foi dito, o animal não sabe que está nu, pois: "não há nudez na natureza. Existe apenas o sentimento, o afeto, a experiência (consciente ou inconsciente) de existir na nudez. Por ele ser nu, sem existir na nudez, o animal não se sente nem se vê nu. Assim, ele não está nu.” (op. cit. p. 17 et. seq.). Aquele sobre quem proferem discursos, mas não participa da construção do discurso, da narrativa de si, assemelha-se ao animal que está nu, sem o saber-se nu. E, conforme Derrida, a mudez é uma espécie de luto.

O Mesmo que habita a primeira margem cobre a sua nudez conforme os padrões determinados. Na segunda margem, porém há o Outro que está nu, com ou sem consciência de sua nudez. A nudez do Outro só existe para aquele que se cobre. Ter uma linguagem, um discurso é vestir-se ou, deixar-se vestir. Alguns costumam vestir os outros com discursos que não lhes caem nada bem, enquanto para si, tecem fios dourados de linguagem preciosa, porém falsa.

Por meio da linguagem, da imposição de um discurso, o Mesmo busca anular a alteridade. Ou seja, difunde-se um discurso que busca estabelecer normas e padrões para que se seja aceito num grupo ou comunidade. Aqueles que não se ajustam a esses padrões, os 
diferentes, tendem a serem excluídos ou considerados como inferiores. Entre o Eu, considerado humano, e o Outro, considerado animal, há o que é próprio do homem, ou seja,

\begin{abstract}
o próprio do homem, sua superioridade assujeitante sobre o animal, seu tornar-sesujeito mesmo, sua historicidade, sua saída da natureza, sua sociabilidade, seu acesso ao saber e à técnica, tudo isso, e tudo o que constitui (em um número não finito de predicados) o próprio do homem, consistiria neste defeito originário, em verdade, neste defeito de propriedade, neste próprio do homem como defeito de propriedade" (DERRIDA, 2002, p. 83).
\end{abstract}

Defeito de propriedade porque torna o homem sujeito a tudo o que lhe é próprio. E, assim, são considerados humanos todos aqueles que se enquadram em determinados padrões aceitos como próprios do homem. Os que não se enquadram, devem buscar se enquadrar e, se isso não for possível, podem passar a serem vistos como menos humanos, como um "não ser" que precisa ser descoberto e dominado.

Portanto, o sujeito tende a refutar tudo aquilo que não se considera como próprio do homem. E não se pode afirmar que seja próprio do homem mudar-se definitivamente para uma canoa e ir viver num rio. A atitude de "Nosso pai" causa espanto em toda a comunidade que, por não encontrar sentido em seu gesto, o classifica, de forma latente, como "doideira". As pessoas evitam comentários a esse respeito perante a família. A família, por sua vez, também se utiliza do silêncio para refutar essa hipótese: "Na nossa casa, a palavra doido não se falava, nunca mais se falou, os anos todos, não se condenava ninguém de doido. Ninguém é doido. Ou, então, todos” (ROSA, 2001, p. 84). Uma estratégia que visa minar as tentativas de enquadramento de "Nosso pai" dentro de uma definição não aceita pela família. Dessa maneira, tenta-se negar o conceito pelo silêncio ou pela generalização. Ou "Nosso pai" pertence à mesmidade dos doidos ou não existem doidos.

Apesar dos apelos e de todas as estratégias utilizadas pela família e pela comunidade de trazer "Nosso pai" de volta à primeira margem, ele nunca mais voltou. A fim de impor obstáculos ao seu empreendimento, decidiram-se por não lhe fornecerem comida. Não obtiveram êxito, e o filho, auxiliado sorrateiramente pela mãe, se incumbiu dessa tarefa. Recorreram ao padre para tentar demovê-lo por dever moral e de consciência. Recorreram a soldados para lhe infligir medo. "Nosso pai" seguia na canoa, indiferente às tentativas de controle e dominação que os habitantes da primeira margem intentaram contra a sua nova forma de viver. É próprio do homem fixar-se na primeira margem e, então, dominar a segunda. Mas não lhe seria próprio, do mesmo modo, forjar para si um lugar alternativo, uma terceira margem? 
Entretanto, uma terceira margem nem sempre é possível de se assimilar, de se apreender. "A gente teve de se acostumar com aquilo. Às penas, que, com aquilo, a gente mesmo nunca se acostumou, em si, na verdade.” (ROSA, 2001, p. 82). Embora estivesse vivendo o fenômeno, o filho não podia se habituar à estranheza que ele causava e que causaria sempre. "Nosso pai" havia ultrapassado o limite que, segundo Derrida, afastaria o homem do animal: a linguagem. E, consequentemente, tornou-se mudo como muda é toda a natureza.

A mudez da natureza, no entanto, não significa impossibilidade de comunicação entre ela e todos os outros seres que a habitam. Comunicar-se pressupõe muito mais do que a decifração de códigos verbais e não verbais, mas é preciso estar atento aos sinais emitidos por cada ser e cada objeto. Portanto, há que se ter ouvidos atentos e, como diz a letra da canção, ouvir a voz das águas.

Mas não apenas a voz das águas, pois a canção expressa uma polifonia, em que vozes e silêncios são atribuídos aos seres e à natureza. Nos versos "Por sob a risca da canoa/ o rio viu, vi/ o que ninguém jamais olvida...", é introduzido também o olhar do rio sobre o acontecimento que ninguém conseguiu esquecer. E há um sujeito que consegue perceber o olhar do rio, ou seja, um olhar completamente isento das interferências da primeira margem. Um olhar que não provém nem da primeira e nem da segunda margem, mas que está próximo de "Nosso pai", como cúmplice de seu gesto.

O silêncio de "Nosso pai” transfere a comunicação às águas, aos objetos, e abre espaço a outras maneiras de se perceber um acontecimento, que vai além do discurso. O cancionista sugere uma imagem em que palavras ganham asa, ou seja, são livres e de amplos alcances. No entanto, relaciona o gesto de "Nosso pai" à asa parada: "Asa da palavra/ asa parada agora". "Nosso pai” não perdera a voz, apenas abdicou do poder de nomear seu próprio gesto e os dos demais. Fez-se necessário, então, estar atento às imagens e aos gestos.

Em se tratando de alteridade, nem sempre o discurso é a maneira mais eficaz de se estabelecer aproximações com o Outro. O sujeito pode estar atento, pode ouvir e ver o Outro os animais, a natureza, os objetos. Contudo, se o sujeito pretende abandonar a primeira margem para ir, de forma aberta, em direção à segunda, é preciso antes mostrar-se. $\mathrm{O}$ animal espreita, ele olha o sujeito, mas o seu olhar tem sido frequentemente ignorado porque o sujeito não deseja se mostrar ao Outro. Derrida, então, questiona-se:

Deveria eu mostrar-me, mas em o fazendo, ver-me nu (e então refletir minha imagem em um espelho) quando isto me olha, esse vivente, esse gato que pode ser captado no mesmo espelho? Existe narcisismo animal? Mas esse gato não pode ser, no fundo de seus olhos, meu primeiro espelho? (idem, 2002, p. 92). 
Esse animal, essa natureza, esse objeto, esse absoluto Outro pode ser captado no mesmo espelho que o sujeito, um espelho que reflete a ambos e expõe as suas diferenças. Contudo, é preciso posicionar-se diante do espelho completamente despido, ou seja, sem disfarces. Assim, o sujeito pode mostrar-se ao Outro, e também enxergar a si próprio simultaneamente, através do reflexo.

É interessante observar que, embora o Outro possa estar ali do lado, ele nem sempre é visto, a não ser por seu reflexo num espelho. Quando não se é possível captar o Outro no fundo de seus olhos, quando não é possível se reconhecer ou se identificar com o Outro, nem acolhê-lo e compreendê-lo com suas diferenças, ao menos no espelho é possível captar a sua existência. Afinal, é a existência do Outro que determina também a existência do sujeito.

As representações artísticas podem ser comparadas a este grande e múltiplo espelho que reflete o sujeito e também reflete o Outro. Um espelho multifocal onde todos podem ser apresentados em maior ou menor definição, às vezes deformados, às vezes fragmentados, enfim, de inúmeras formas e tamanhos diferentes. Mas, apesar de apresentar apenas reflexos e, portanto, sujeitarem-se a distorções, muitas vezes é somente através das representações artísticas que o sujeito percebe o Outro.

A instalação artística de Guto Lacaz demonstra bem o quanto as pessoas se surpreendem ao constatar a existência de uma terceira canoa. Cajuína é o avesso de Terra, ela é o absoluto Outro, notada apenas pelo artifício do espelho. Não é impossível perceber que Cajuína se encontra ali, do avesso, mas aqueles que se posicionam na primeira margem, onde se encontra a canoa Terra, não se dão conta de sua existência, a não ser quando ela se reflete no espelho.

Enquanto o sujeito permanece fixo, centrado em suas próprias configurações, não consegue captar o absoluto Outro. Para isso é preciso deixar a comodidade da primeira margem, e se aventurar a perseguir a segunda que, de tão distante, não pode ser alcançada. Mas, ao movimentar-se em direção ao Outro, eis que o sujeito se mostra, olha finalmente o Outro e pode até mesmo ver-se visto por ele.

\subsection{Recursos estéticos: alteridade}

Arte e literatura são expressões da condição humana, em que um indivíduo comunica a outro as suas impressões. Assim, habitantes de um mesmo universo, partilhando da mesma condição de seres limitados, mas conscientes e interativos, cada indivíduo pode encontrar nas 
mais diversas formas de arte, um pouco de sua própria história, além de compartilhar experiências.

Muitos trabalhos sociais e estudos científicos são feitos a fim de se descobrir e conhecer mais a respeito do ser humano. Entretanto, embora todos esses trabalhos e estudos sejam de grande importância para se atingir o objetivo proposto, é por meio da arte e, principalmente, da literatura, que um ser humano consegue aproximar-se mais intimamente de outro, sem tocar, sem olhares cruzados, enfim, à distância.

Da mesma forma que o artista precisa se afastar da obra para melhor analisá-la, para enxergá-la de forma mais completa, também o ser humano pode ser visto mais amplamente e de vários ângulos quando apreciado à distância proporcionada pela literatura. E não somente a literatura promove a abertura do olhar à paisagem infinita que é a vida humana, mas também todas as outras formas de arte. A diferença se encontra no fato de que, devido ao caráter sequencial do discurso verbal, essa vida vai sendo desvendada aos poucos, porém amplamente, possibilitando ainda tempo de reflexão a cada etapa.

A obra literária é capaz de expressar a vida humana em sua complexidade, em sua miséria, em suas glórias e limitações, enfim em seus mais diversos pensamentos, ideias e emoções. Embora a leitura de estudos teóricos ajudem a formular questões e a encontrar explicações para o comportamento humano, é a leitura de obras literárias que tem a capacidade de movimentar o espírito humano rumo ao fascínio do Outro, considerando-se que

\footnotetext{
a leitura de romances [...] tem menos a ver com a leitura de obras científicas, filosóficas ou políticas do que com outro tipo bem distinto de experiência: a do encontro com outros indivíduos. Conhecer novas personagens é como encontrar novas pessoas, com a diferença de que podemos descobri-las interiormente de imediato, pois cada ação tem o ponto de vista de seu autor. Quanto menos essas personagens se parecem conosco, mais elas ampliam nosso horizonte, enriquecendo assim nosso universo. Essa amplitude interior (semelhante a que nos proporciona a pintura figurativa) não se formula com proposições abstratas, e é por isso que temos tanta dificuldade em descrevê-la; ela representa, antes, a inclusão na nossa consciência de novas maneiras de ser, ao lado daquelas que já possuímos. (TODOROV, 2009, p. 81)
}

Arte e literatura, por abrigar expressões de alteridade, fomentam o encontro e o acolhimento das mais diversas formas de existência, expõe o ser humano às mais diversas situações reais e imaginárias, enriquecendo as suas experiências de mundo. Com isso também participam da formação da identidade individual, da tomada de consciência em relação ao Outro e da construção de uma narrativa de si subsidiada não apenas pelas experiências reais vividas pelo sujeito, mas também das que ele alcança pela leitura das narrativas históricas e de ficção. 
As emoções suscitadas pelas narrativas literárias, porém são distintas das emoções conseguidas pela apreciação de outras artes. Pela importância que tais narrativas exercem na consciência e na experiência de vida das pessoas é que muitas se tornam conteúdo de outras formas artísticas. As transposições de linguagens então se transformam num meio de compartilhar os sentimentos e os sentidos que a obra original despertou no artista. Assim, a arte difunde a alteridade intrínseca da obra (considerando-se, em arte, a imagem/o som do Outro) e também a alteridade do artista que foi impulsionado por ela a criar uma nova obra.

Nesse processo de transposição de linguagens artísticas, há que se verificar, portanto, como cada uma delas aborda, por meio de seus componentes artísticos, as questões de alteridade. Segundo Blanchot (2011, p.142). "somos seres limitados. Quando estamos aqui, é na condição de renunciarmos estarmos acolá: o limite detém-nos, retém-nos, rechaça-nos para o que somos, voltamos para nós, desvia-nos do outro, faz de nós seres desviados". Entretanto, a arte e a literatura lançam-se em direção ao Outro mesmo esbarrando nas limitações que esse empreendimento comporta.

O artista que se propõe a construir uma obra de arte autônoma e aberta, precisa antes libertar-se também dos limites que o desviam dos outros. A obra de arte não deve ficar limitada ao universo do autor, apesar de que é desse universo que ela parte. Cabe ao autor lançar-se ao encontro do absoluto Outro, para que, nesse caminho, seja construída uma obra de arte autêntica.

Mesmo quando o conteúdo da obra provém das experiências do autor ou da sua interpretação de uma obra anterior, a diferença é que a sua realização empreendeu uma ruptura com os limites do próprio autor, abrindo-se ao que lhe era externo, ou seja, a alteridade. Em arte e literatura é possível vislumbrar a alteridade de todas as coisas, conforme as considerações de Levinas (2004 p. 32): “podem as coisas tomar um rosto? A arte não é uma atividade que confere rosto às coisas? A fachada de uma casa não é uma casa que nos olha?".

Na canção de Caetano, as coisas possuem um rosto, olham, riem, comunicam: "oco de pau" diz daquilo que ele pode se tornar, ou seja, há menção à mensagem visual que a madeira apresenta àquele que pretende fazer dela uma canoa. A madeira, o absoluto Outro da canção, se comunica por meio de recursos não verbais. Entretanto, a mensagem que se decifra será sempre aquela que é mais adequada a determinados propósitos. Vale dizer que seleciona-se, de todo o potencial comunicativo dos elementos, aquilo que, no momento, parece ser mais interessante a quem realiza a seleção. 
O problema reside em que, frequentemente, parte-se de si próprio almejando se chegar ao Outro. Ora, a madeira pode servir a muitas finalidades, mas na canção ela comunica a "Nosso pai" que pode se tornar mais do que canoa, ela "dá vau", ou seja, pode ser usada para atravessar o rio. De início, a madeira é o absoluto Outro para "Nosso pai”, que a enxerga de seus próprios limites, sem se preocupar com a complexidade de mensagens que uma madeira encerra. O rio que a canoa risca também é o absoluto Outro, todavia, quando ele é invadido pela canoa e por "Nosso pai", forma-se nele uma risca terceira. Madeira, homem e rio se encontram, e o absoluto Outro deixa de existir. É na terceira margem que o Outro começa a ser assimilado num processo de diluição de um para o outro que jamais se esgota. Não que os limites tenham sido transpostos como se transpõe uma fronteira, mas que um se confunde no outro sem renunciar à sua subjetividade.

"Nosso pai" segue em silêncio, contudo, o risco da canoa que se desenha no rio comunica ao filho uma mensagem. A risca terceira, o ponto de assimilação do absoluto Outro, converte-se em código a ser decifrado pelo filho. Cúmplice do pai e da canoa, o rio ri, justamente no desenho que a canoa risca em suas águas. Ri porque é nessa risca, nesse riso, que se encontra o enigma que o filho busca desvendar. Mas o filho não ousa lançar-se ao ponto de encontro do absoluto Outro, desvia-se, retorna a si mesmo sem jamais conseguir entender a atitude de "Nosso pai".

A exigência que a arte e a literatura impõem é equivalente a esse encontro. $\mathrm{O}$ artista tem que se desviar de si e lançar-se ao absoluto Outro abertamente. Isso não quer dizer que o artista alcança o Outro, pois ele só pode ser atingido à distância. Entretanto, o lançar-se em direção ao Outro é como buscar o objetivo de atingir uma terceira margem. Aquele que nada em direção ao Outro tem que sair de si mesmo, abandonar tudo o que o encerra em si e na mesmidade, com o olhar do animal a que também se refere Blanchot (2011, p. 144): "pela morte, 'nós olhamos para fora com um grande olhar de animal'. Pela morte os olhos mudam de direção e essa viragem é o outro lado, e o outro lado é o fato de não viver desviado, mas redirecionado, introduzido agora na intimidade da conversão [...]".

Quando decidiu mandar construir a canoa e ir viver no rio, "Nosso pai" não estava se desviando da família, mas a sua vida a partir daquele momento estava sendo redirecionada. "Nosso pai não voltou. Ele não tinha ido a nenhuma parte. Só executava a invenção de se permanecer naqueles espaços do rio, de meio a meio, sempre dentro da canoa, para dela não saltar, nunca mais". (ROSA, 2001, p. 80). O redirecionamento que se deu quando de sua entrada na canoa introduziu à sua vida o estatuto da morte: o outro lado, o lado do 
desconhecido, tornou-se agora o seu lugar. A canoa, feita sob medida para o canoeiro, equivale-se a um ataúde que o abriga em silêncio sepulcral.

O pai que se cala, que segue na canoa silencioso, sério, é como o artista que busca o absoluto Outro: tem que abandonar-se de si mesmo e de tudo aquilo que o liga ao seu mundo. Segue em silêncio, ou seja, ele se cala para dar voz à terceira margem, à canoa, ao rio, enfim ao absoluto Outro. Ele morre para que o Outro viva. Em outras palavras:

\begin{abstract}
A criação estética não poderia ser explicada ou pensada como imanente a uma única e mesma consciência, o acontecimento estético não pode ter um único participante que, simultaneamente, viveria a vida e expressaria sua vivência pessoal através de uma forma artística significante; o sujeito da vida e o sujeito da atividade estética, que lhe dá a sua forma, não podem por princípio coincidir. Há acontecimentos que, por princípio, não podem desenvolver-se no plano de uma única e mesma consciência e pressupõem duas consciências estanques; pois o componente essencial do acontecimento é essa relação de uma consciência com outra. (BAKHTIN, 1997, p. 102).
\end{abstract}

Se "Nosso pai" não construísse a canoa, muda estaria a mensagem que ele decifrou a partir do oco de pau. Se "Nosso pai" não adentrasse o rio com sua canoa, de que outra maneira poderia o rio rir? Mas esse riso, “a voz das águas”, quem nos permitiu ouvir foi Caetano Veloso. Portanto, se Caetano não silenciasse a narrativa de si para fazer falar o rio, as águas, a canoa, estaria muda essa voz, estaria oculto esse rosto que o artista ouviu e viu primeiro para depois levar a público.

Embora a linguagem não possa expressar com exatidão todas as coisas, ela aponta rumos a serem percorridos, sinais que podem ser decifrados. Pela linguagem, o absoluto Outro se assemelha ao fingimento, quando não conseguimos definir se trata-se de fingimento ou não. Não seria tal estatuto aplicável à literatura? O rosto que a literatura nos mostra pode não ser autêntico, mas como saber?

Quanto à instalação de Guto Lacaz, ao introduzir um espelho entre as duas canoas, redireciona o olhar do espectador, conduzindo-o a enxergar Cajuína. Alguns, porém poderão desviar-se para, no espelho, continuar encontrando apenas a sua própria imagem. A obra suscita, assim, reflexões quanto aos procedimentos que identificam o Outro como reflexo do Eu. Conforme afirma Burke (2004, p. 154): "É através da analogia que o exótico se torna inteligível, domesticado". Quando não se consegue assimilar o exótico, intenta-se domesticálo por meio de analogias e, assim, suportar o incômodo que o seu assombro causa. A analogia é um procedimento comum aos que insistem em se desviarem dos outros, buscando encontrar neles a sua própria imagem duplicada como num espelho. 
Cajuína é, na instalação artística, o absoluto Outro, que se encontra na terceira margem e que só pode ser visto se o espectador sair de seu ângulo e se posicionar de forma apropriada em relação às canoas. Caso contrário, tudo o que encontrará no espelho é o reflexo do seu próprio Eu. A dificuldade reside em que, para enxergar o Outro, é necessário educar o olhar a se dirigir para fora, para o exterior de si, abdicar ao cômodo espaço de seu ponto de vista usual, para ocupar espaços completamente outros.

No conto, o filho não consegue atingir a alteridade de "Nosso pai" porque está acoplado a ele, na qualidade de filho. Ele busca identificar-se com o pai, mas acaba por construir uma relação em que a identidade do pai se confunde com a sua própria identidade. Ele gostaria de poder resguardar a identidade do pai porque assim estaria resguardando a sua própria identidade:

\footnotetext{
Às vezes, algum conhecido nosso achava que eu ia ficando mais parecido com nosso pai. Mas eu sabia que ele agora virara cabeludo, barbudo, de unhas grandes, mal e magro, ficado preto de sol e dos pêlos, com o aspecto de bicho, conforme quase nu, mesmo dispondo das peças de roupas que a gente de tempos em tempos fornecia.

Nem queria saber de nós; não tinha afeto? Mas, por afeto mesmo, de respeito, sempre que às vezes me louvavam, por causa de algum meu bom procedimento, eu falava: - "Foi pai que um dia me ensinou a fazer assim..."; o que não era o certo, exato; mas, que era mentira por verdade. (Rosa, 2001, p. 83).
}

Verifica-se aí a insistência do narrador em conformar-se ao pai, mesmo sabendo que ele se modificara completamente. $\mathrm{O}$ narrador parece lastimar que, devido ao empreendimento de ir viver numa canoa, "Nosso pai" não possa mais se assemelhar a ele. O narrador não pode deixar de existir como filho e, portanto, não pode suportar que haja o homem na canoa, no rio, que já não é seu pai, mas um absoluto Outro.

Acolher esse Outro significaria desviar-se de si, deixar de existir como filho, e encontrar o canoeiro com olhar aberto, converter o seu olhar de filho no olhar aberto do animal. Porém, ao produzir as narrativas de si, o filho esbarra sempre no acontecimento extraordinário que interrompeu bruscamente sua convivência paterna. Sua busca pelo pai antecede e obsta o encontro com o Outro, com o canoeiro misterioso ao qual ele procura ainda alguma identificação.

Entretanto, identificar-se pressupõe uma espécie de relação que insere o Outro ora em seus próprios conceitos, ora como oposição a eles. A imagem do espelho demonstra bem a situação: O espelho reflete a canoa e o nome da canoa, porém de forma invertida. Portanto, ora o sujeito vê a si mesmo no espelho, ora vê o Outro, porém de forma invertida, tomado como oposição a si. Conflito que o narrador experimenta durante toda a vida. Às vezes 
identifica o pai como um animal, um bicho completamente oposto a si, às vezes procura identificar no pai a mesma condição humana a ele imposta: "Eu sofria já o começo de velhice — esta vida era só o demoramento. Eu mesmo tinha achaques, ânsias, cá de baixo, cansaços, perrenguice de reumatismo. E ele? Por quê? Devia de padecer demais". (ibidem, p. 84). "Vivenciar o sofrimento do outro é iniciar um fato existencial novo que só pode ser realizado por mim, a partir da posição que sou o único a ocupar e que me coloca interiormente fora do outro". (Bakhtin, 1997, p. 118).

O filho passa toda a vida tentando entender o acontecimento que apartara seu pai de si. Ele não consegue existir como filho, tampouco como pai. O Outro é, dessa forma, aquele que impede o Eu de existir, pois assumir a tarefa de lançar-se ao Outro equivale a estar morto. Eis a razão porque o filho não pode tomar o lugar do pai: não foi capaz de despojar-se de si mesmo. Então ele reconhece que somente após a sua morte será capaz de chegar à terceira margem do rio e assumir o lugar do pai.

Arte e literatura pressionam o artista para que assuma a sua morte, exercem sobre ele uma força de atração que o arrasta à terceira margem. $\mathrm{O}$ artista que resiste reflete-se em sua arte repetidamente como num espelho, mas não extrapola a sua condição e, portanto, não alcança esse lugar sagrado e enigmático que é a terceira margem. Lugar de superposição de subjetividades.

Do artista, porém, não é exigida apenas a sua morte, é exigido que, por ela seja originada a vida. Isso significa que ao artista não basta o acolhimento incondicional da subjetividade do Outro, mas é necessária também a transmissão da subjetividade que ele acolheu. A fim de dar conta desse empreendimento, o artista lança mão dos recursos de sua arte, porém sem nunca atingir a totalidade daquilo que ele acolheu, pois o absoluto Outro jamais se deixar tocar completamente e nem é possível a sua fiel transmissão. Então,

tal como antes, é destino das artes opor-se à realidade e, por meio dessa oposição, compensar a vida do que lhe foi despojado pela realidade e, assim, indiretamente, tornar a realidade suportável, protegendo-a contra as consequências de uma cegueira auto-infligida. (BAUMAN, 1998, p. 158).

Pela arte é possível o alter-ego de uma canoa, de um rio. É possível, pela linguagem literária, estabelecer relações de alteridade entre pessoas e também com o mundo. O artista cosmomorfiza-se, ou seja, ele se projeta nas coisas, deixa de ser pessoa para se tornar objeto e constrói, assim a terceira margem, único lugar onde isso é possível. 
$\mathrm{O}$ artista se comunica com objetos inanimados, mais do que isso, ele se torna um objeto. Não é o mesmo que antropomorfizar-se, pois não se trata de um objeto que ganha aspectos humanos, mas o contrário: o artista é um ser humano que decide atribuir a si próprio aspectos de objeto. Kafka não é um caso de antropomorfose, mas de cosmomorfose. Nesse sentido, o inseto é elevado à condição humana, mantendo-se inseto. É o humano que se faz inseto para melhor captar seus sentidos. O humano que deve descer de sua ilusória superioridade para conformar-se aos outros seres e objetos. Isso é o que arte e literatura exigem do artista. Fazer falar, promover o discurso de todas as coisas, dar voz ao que se cala. Quanto à qualidade e fidedignidade dessa voz pela qual o artista é responsável, cabe ao crítico verificar e promover as discussões pertinentes.

O absoluto Outro não é acessível enquanto parte de uma realidade oposta a do sujeito, porém, por meio da arte, ele é convidado a suportar essa oposição. As consequências disso são o abrir os olhos e enxergar além de si mesmo. Cajuína, a canoa oposta à Terra, oculta, pode ser vislumbrada primeiro no espelho e, uma vez constatada a sua existência, passa a ser inserida como realidade oposta à Terra. Sem o espelho, Cajuína pode passar despercebida ou pode ser vista apenas como parte da canoa Terra. Alguns desejariam pintar Cajuína com a mesma cor de Terra para, assim, conformar as duas canoas e adequá-las à mesmidade. Mas no espelho Cajuína pode ser vista como canoa autônoma, diferente de Terra, ligada a ela, mas não a mesma canoa.

De forma semelhante, cada linguagem artística dispõe de recursos próprios que possibilitam ao artista a transmissão de suas ideias e pensamentos. Assim, a linguagem figurada, as analogias e os símbolos são constantemente requisitados para comunicar a subjetividade da vida e das coisas. Embora a alteridade não possa ser expressa com exatidão por meio da arte e da literatura, o artista dispõe de recursos estéticos que auxiliam a sua transmissão, além das ideias e emoções culturalmente inseridas no imaginário cultural.

Na canção, Caetano usa a metáfora da água como origem da vida para abordar considerações semelhantes sobre a palavra. A palavra, como a água, é ambígua; pode ser obscura ou transparente e encerra significados de morte e de vida. A palavra também pode causar turbulências e devastar ideias, conceitos, pré-conceitos; portanto, constroem-se barreiras e limitações à palavra, pois ela, como a água, possui a capacidade de infiltrar-se muito profundamente de forma destruidora, mas também purificante. Caetano menciona ainda, o autor do conto que originou a canção, em sua rigidez ao usar abertamente as palavras: “água de Rosa, dura”. 
A linguagem tende a definir, conceituar, entretanto, não é possível, pela via do discurso, atingir a terceira margem. Ela é movimento constante em direção ao Outro e, se esse movimento for definido, cessa. $\mathrm{O}$ autor lança mão de recursos linguísticos, valendo-se do uso dos substantivos água, proa, margem, clareira, Rosa, silêncio, asa, casa, brasa, hora e tora para gerar imagens que possam aproximar o receptor da ideia de uma palavra que é movimento constante mesmo quando está parada, ou seja, no silêncio que também encerra um discurso. Segundo Foucault (2000, p. 132): "a linguagem é toda ela discurso, em virtude desse singular poder de uma palavra que passa por sobre o sistema dos signos em direção ao ser daquilo que é significado." Então, o artista tem diante de si a limitação da linguagem como discurso. Suprimidas as palavras do pai, silencia-se o discurso. Faz-se necessário, a partir daí, ater-se a outros signos, abrindo-se os horizontes discursivos à imagem. Guto Lacaz, com sua instalação, transpõe da linguagem escrita à linguagem visual o tema proposto pela canção. A imagem não pretende dar conta de todo discurso suscitado pela canção, mas apenas mostrar, da forma mais próxima do concreto, uma síntese, um fragmento do enigma do Outro que está lá, na terceira margem do rio.

O absoluto Outro é, enfim, todo elemento externo, que não se pode acessar a não ser com a condição de se afastar de si mesmo. Artes visuais e literatura contam com recursos próprios de sua linguagem na realização desse empreendimento. Caetano Veloso, na letra de sua canção, adota recursos linguísticos que favorecem com sonoridade, formulação de imagens e trocadilhos, a comunicação da alteridade presente em todos os elementos de $A$ terceira margem do rio.

Guto Lacaz, em sua instalação artística, proporciona ao observador interagir com a proposta da terceira margem, utilizando-se de recurso ótico e simbólicos. Além disso, transpõe o tema da linguagem escrita à linguagem visual, tornando-o imagem concreta.

O texto escrito, a palavra, a poesia, possibilitam comunicar um tema em detalhes e de forma abrangente. A imagem, porém, tende a sintetizar, fragmentar. Não obstante, por sua capacidade de síntese e por sua comunicação imediata, tem se tornado cada vez mais relevante para a transmissão e absorção de mensagens. Portanto, texto e imagem servem a diferentes propostas de comunicação e transmissão de mensagens. A terceira margem do rio, em seus formatos conto, poesia e instalação artística, traz conteúdo autônomo e, ao mesmo tempo, complementar. Uma linguagem artística não visa excluir nem superar a outra, mas apresentar uma nova abordagem em relação ao tema. Como a instalação artística demonstrou, é necessário sair de si mesmo, posicionar-se em determinado ângulo para se enxergar o Outro, ou a outra forma de expressar um assunto. 


\subsection{Considerações sobre leitura e interpretação}

Embora os termos paródia, paráfrase e estilização sejam frequentemente usados para designar as relações intra e intertextos, aqui serão relacionados também aos processos comunicativos entre literatura e outras artes. O objetivo é extrapolar os limites do discurso enquanto texto para analisá-lo em suas versões visuais e na canção. Enfim, esses termos serão investigados ainda, ao longo deste estudo, quanto à sua aplicabilidade, por analogia, aos relacionamentos interartes.

Conforme os filósofos da escola francesa, Michael Foucault, Jacques Derrida e Maurice Blanchot, o texto não deve ser entendido como discurso fechado em si, nem aprisionado nas intenções do autor, mas como movimento constante que se realiza a partir de diversas possibilidades de leitura. E, considerando-se que a leitura é bem mais do que a simples decifração de códigos linguísticos, deve-se incentivar também a leitura de imagens e de sons. Portanto, é possível verificar, nas transposições de linguagem, ou nas traduções intersemióticas a realização concreta de uma leitura. Não significa que uma obra visual ou uma canção possam encerrar o sentido do texto, e nem que possam ensejar a sua substituição, mas apenas apresentar uma forma de "ler" o texto, que ultrapassa a sua condição escrita. E isso ocorre quando o texto deixa de ser um discurso fechado, guardião da verdade absoluta, e abre-se à liberdade de criações que a leitura pode sugerir. E, como conclui Santana (2003, p. 89): "por isso é importante finalizar esclarecendo uma vez mais que o discurso em sua plenitude só se realiza quando se desenvolvem várias linguagens simultâneas e interdependentes".

Foucault ressalta três grandes procedimentos de exclusão do discurso em uma sociedade, destacando entre esses procedimentos, a vontade de verdade. A vontade de verdade fomenta a imposição de um discurso que, por se revestir de verdadeiro, interdita os demais, oprime as possibilidades de interpretação que estejam na contramão dos interesses daqueles que detém o poder. E até mesmo no interior de um discurso vigoram procedimentos de exclusão e de controle. A arte contemporânea, no entanto, tem mostrado autonomia quanto à vontade de verdade, pois não interessa a ela encontrar a verdade nas produções artísticas, mas ampliar as possibilidades discursivas das questões abordadas. Tampouco demonstra submeterse aos sistemas de controle internos, uma vez que se apropria, sem cerimônias, do discurso produzido internamente, bem como do de outras áreas artísticas.

Todavia, é possível considerar também que, nos intertextos e nas produções interartes contemporâneas exista uma busca pela verdade, ou, pelo menos, pela afirmação da verdade 
percebida em cada ponto de vista. O artista busca, assim, apresentar a sua versão a respeito das criações de seus antepassados, reapresentando-as, segundo o paradigma moderno. Texto, imagem e som organizam-se para dar conta das inúmeras verdades que se encontram inseridas em determinado discurso. Seja convergindo ou discordando, cada linguagem, a seu modo, busca afirmar a sua versão: "porque a questão da paródia, da paráfrase, da estilização e da apropriação está relacionada, em última instância, com a procura da verdade.” (SANTANA, op. cit. p.72).

A busca pela verdade também interfere nos encaminhamentos que o leitor determina em sua seleção de textos e leituras. A partir de concepções pré-determinadas, as leituras são realizadas com o intuito de convergir ou de gerar confronto com suas próprias ideias. De qualquer maneira, as produções artísticas contemporâneas que promovem intertextos e interdiscursos com obras anteriores, também terminam por difundir interpretações de convergência ou divergência com as obras originais.

Enfim, a transposição de linguagens artísticas se apresenta como forma de difusão dos pensamentos, imagens e ideias que uma obra pode suscitar no leitor. Entretanto, não devem ser consideradas como síntese ou como revelação da verdade da obra original. O que se deve ter sempre em mente é que se trata de uma interpretação da obra, que não intenta substituí-la e nem superá-la, mas apenas apresentá-la de forma diferente e conforme a interpretação de um leitor.

A leitura da obra original, portanto, é imprescindível para a discussão e o aproveitamento intelectual/estético das obras decorrentes dos intertextos, especialmente no contexto atual em que são oferecidas ao leitor inúmeras possibilidades de livros, textos e imagens. Além de saber interpretar textos e imagens, do leitor atual é exigido também que se faça uma seleção rigorosa sobre autores, leituras e ideologias que afetam os encaminhamentos que podem ser dados aos mais diversos tipos de textos.

O amplo acesso a livros e textos, assim como as leituras superficiais e fragmentadas podem confundir e desanimar o leitor indeciso. George Steiner, em seu ensaio O leitor incomum (2001) aponta para uma "revolução de valores", no que diz respeito à conduta do leitor nos tempos atuais, comparada a dos séculos XVII e XVIII. Steiner observa que a leitura como parte de um ritual, feita com reverência, tem sido substituída pela leitura não sequencial, seletiva e autônoma.

O leitor contemporâneo tornou-se, assim, um sintetizador e selecionador. Devido ao arcabouço de assuntos, textos e informações disponíveis, o leitor pós-moderno faz incontáveis leituras fragmentadas, a fim de selecionar, em meio aos temas de seu interesse, o enfoque e 
estilo mais adequados às suas finalidades de leitura. Apesar da impossibilidade em se deter em todos os textos convenientes aos seus interesses, o leitor busca reunir fragmentos e resumos e, a partir deles, definir o direcionamento que pretende dar às suas leituras e estudos.

Portanto, o leitor e o artista pós-modernos, buscam, em meio à diversidade de produções e reproduções de textos e imagens, aquelas que melhor se adaptam às suas necessidades, e acabam por fazer associações e novas produções a partir dessa seleção. Tratase de um processo que fomenta a abertura dos temas às mais diversas formas com que possam ser manipulados. Por meio de imagens, sons e textos, os temas sofrem manipulações estéticas, sociais, culturais, políticas, ideológicas, enfim, adaptam-se às pretensões de seus autores.

Walter Benjamim, em seu ensaio A obra de arte na era de sua reprodutibilidade técnica (2000), já prenunciava o desgaste sofrido pela obra de arte devido às muitas possibilidades de manipulação a que ela se tornou sujeita a partir da era tecnológica. Embora o ensaio seja dirigido mais especificamente às artes visuais, hoje se tornou evidente o desgaste das obras literárias clássicas a partir das muitas formas pelas quais elas têm sido reproduzidas, transformadas, manipuladas, enfim, entregues aos mais diversos tipos de usos que a tecnologia é capaz de promover, para atender a objetivos educacionais, publicitários, comerciais, financeiros, entre outros.

As reproduções e apropriações das obras acabam por ser mais difundidas do que os originais, devido à facilidade de divulgação que a tecnologia proporciona. Entretanto, ainda que haja a preservação de conteúdo do original, há também a perda da "aura", ou seja, da originalidade e natureza única que a obra suscita em seu caráter de autenticidade. As funções sociais da arte vão se transformando conforme os apelos e necessidades de cada sociedade, surgindo, então, as adaptações e as novas formas de se conviver com as mudanças. Não obstante o desgaste das obras e a perda da "aura", as reproduções técnicas e as apropriações vão se impondo cada vez mais nas sociedades modernas e tendem a encontrar o seu espaço e sua função.

As artes visuais e cênicas, ao apropriar-se de conteúdos de obras literárias, acabam por contribuir com a inserção real do texto na comunidade. De acordo com Paul Zumthor (2007), a recepção do texto tem a ver com a maneira como ele é colocado na comunidade, seja por meio da expressão oral ou da performance. De qualquer maneira, quando o texto, por meio da recepção, extrapola a sua condição escrita e se torna também voz, corpo e imagem, então, pode-se dizer que este texto foi imerso naquela comunidade, que se tornou parte da cultura daquele lugar e ali se insere como elemento indissociável de sua história. Esse processo de 
apropriação não é fechado e nem linear, mas ocorre tanto a partir da literatura em direção às outras artes, como destas à literatura.

A obra de Guimarães Rosa possui atributos que ensejam a sua inserção real numa comunidade. A elaboração linguística do texto confere à narrativa escrita aspectos de oralidade e de conversa íntima, introduzindo o leitor ao universo dos personagens e dos ambientes retratados. Sua abordagem do regionalismo diferencia-se de outros autores do modernismo, na medida em que o autor busca enfatizar a expressão da vida humana em situações e ambientes inóspitos. Enfim, a obra rosiana se infiltra no imaginário social de maneira contundente, abrindo espaços e forjando passagens para que ambientes e personagens marginais se manifestem sem eufemismos.

$\mathrm{O}$ conto A terceira margem do rio, tem sido explorado de muitas formas pelo imaginário social brasileiro. Tem inspirado canções, artes visuais, produções teatrais e cinematográficas. Seu título é usado com frequência para se referir a algo indefinido, inusitado. A telenovela Pantanal, da extinta Rede Manchete, mesclando, possivelmente, um mito pantaneiro ao conto, ajudou a popularizar a história. Na trama, há um personagem mítico, uma entidade dúbia entre ser humano e natureza, imanência e transcendência, conhecido como o "Velho do rio". Conformando-se ao mito pantaneiro, o "Velho do rio" aparece aos que foram mordidos de cobra, auxiliando-os no tratamento contra o veneno. Conformando-se ao conto, o "Velho do rio" é o pai do protagonista, que um dia abandonou a família e foi morar no rio. No final da telenovela, diferentemente do conto, o filho assume o lugar do pai. A linguagem, no texto de Benedito Rui Barbosa, é nitidamente influenciada por Guimarães Rosa. A telenovela foi exibida originalmente no ano de 1990.

Nos seus mais diversos intertextos e interdiscursos, é possível afirmar que o conto $A$ terceira margem do rio foi inserido de forma real na sociedade brasileira. A recepção do conto inspirou outras produções artísticas, e seu título se transformou em uma expressão linguística no Brasil, considerando-se que a expressão "terceira margem do rio", vem sendo usada nas mais diversas situações, valendo-se dessa imagem criada por Rosa. Recentemente, num artigo sobre política, ao comentar situação indecisa da candidata à presidência da República Marina Silva (PSB), o jornalista Plínio Fraga ${ }^{6}$ escreveu: "Marina rema em direção à terceira margem do rio para contornar conflito situação/oposição." Ainda que nem todos conheçam o conto, cada vez mais ele vai se tornando parte do imaginário social brasileiro.

\footnotetext{
${ }^{6}$ Disponível no dia 04 de setembro de 2014 em: http://br.notícias.yahoo.com/blogs/plinio-fraga/marina-remaem-direção-à-terceira-margem-do-rio-para-contornar-conflito-situação-oposição-192728921.html
} 
Entretanto, ao afirmar que o texto se inseriu de forma real na sociedade brasileira, por meio das performances teatrais, cinema, novela, artes visuais e expressões linguísticas, isso não significa que tal inserção esteja imune às acomodações e adaptações de linguagem e ideias. Ao contrário, como já foi comentado, as funções da arte sofrem transformações na sociedade, transformações que afetam as reproduções de textos mais antigos e as novas produções. Portanto, o artista é livre para criar novos sentidos, gerar novas reflexões, influenciado pelas produções de seus antepassados e, assim, realizar transposições artísticas que atualizem as obras originais em linguagem, tempo e contexto.

Não obstante a liberdade de criação do artista e sua licença poética, o trabalho de transposição de linguagens exige interpretação e, portanto, se sujeita aos seus limites. Conforme as constatações de Umberto Eco, em seu livro Os limites da interpretação (1990), apesar das inúmeras possibilidades de leitura de um texto, fundamentadas pela semiótica, é necessário estabelecer critérios à interpretação. Esses critérios não visam ao biografismo ${ }^{7}$, tampouco pretende, como sugerem as correntes formalistas ${ }^{8}$ de análise, encerrar no próprio texto todas as demandas da leitura. Conforme Joly:

Com efeito, a análise textual (ou seja, a análise intrínseca de uma obra) ensinou-nos, na sequência do estruturalismo dos anos 60, a examinar as diferentes unidades de significação de uma mensagem e a fazer a sua síntese. Este tipo de análise, novo na época, teve o mérito de incitar o leitor crítico a se ater em primeiro lugar à obra (ou texto) para a explicar, o que sucedeu como reação às críticas tradicionais que consistiam em falar de tudo exceto da própria obra. (idem, 2007, p. 69).

Umberto Eco, embora destaque a importância do leitor nesse processo, confluindo com a estética da recepção ${ }^{9}$, procura, em sua obra, estabelecer critérios que auxiliem na distinção entre interpretação e usos do texto, que serão averiguados mais detalhadamente aqui, ao se tratar das questões relativas às estilizações nas artes e na literatura.

Na obra Interpretação e Superinterpretação, Eco também demonstra a necessidade de se apurar até que ponto a liberdade de interpretação do leitor não interfere no conteúdo da obra. Refuta as concepções de análise do texto baseadas nas intenções do autor, pois as considera irrelevantes ao trabalho de interpretação. Entretanto, admite a lacuna quanto a uma

\footnotetext{
${ }^{7}$ Modo de abordagem dos textos literários que buscava explicar o texto, determinar a sua verdade, partindo, principalmente, da biografia do autor.

${ }^{8}$ Corrente teórica russa em que se priorizam os elementos formais do texto, tornando sua análise crítica independente.

${ }^{9}$ Corrente teórica que percebe a leitura como objeto de construção de significados, e não uma operação meramente decodificadora.
} 
teoria que, sem recorrer à intenção do autor, seja suficientemente embasada para impor limites às intenções do leitor que possam deturpar o sentido geral de um texto. Então,

\begin{abstract}
poderíamos objetar que a única alternativa a uma teoria radical da interpretação voltada para o leitor é aquela celebrada pelos que dizem que a única interpretação válida tem por objetivo descobrir a intenção original do autor. Em alguns dos meus escritos recentes, sugeri que entre a intenção do autor (muito difícil de descobrir e frequentemente irrelevante para a interpretação de um texto) e a intenção do intérprete que (para citar Richard Rorty) simplesmente "desbasta o texto até chegar a uma forma que sirva a seu propósito" existe uma terceira possibilidade. Existe a intenção do texto. (ECO, 2005, p.29).
\end{abstract}

O autor propõe, enfim, uma terceira possibilidade, que visa a acolher as intenções do leitor, porém, a fim de se preservar o texto das más intenções, impor-lhes um limite razoável, que, por fim, é definido pelo próprio texto. Isso não significa um retorno ao estruturalismo ${ }^{10}$, pois a intenção do texto é requerida para averiguar certas interpretações tendenciosas, não como única fonte válida de pesquisa. O objetivo da leitura não é o de desvendar o segredo do texto, ou descobrir a sua verdade. Ao contrário, o objetivo é preservar o segredo do texto, desfavorecendo a imposição de qualquer autoridade sobre seu sentido. $\mathrm{O}$ intérprete, como nas concepções que priorizam as intenções do leitor, é livre para construir sentidos coletivos e particulares a partir do texto, porém deverá ser capaz de justificar, no próprio texto, suas construções e não fora dele.

Portanto, embora sejam lícitos os usos do texto, não são dignos de serem chamados de interpretação quando esses usos precisam recorrer a elementos exteriores ao texto a fim de se sustentarem. No que respeita às transposições de linguagem, o uso ou interpretação do texto original afeta, de modo decisivo, o resultado obtido.

Seja como for, ao produzir uma obra tomando por base outra, o artista deve procurar realizar, antes, a interpretação da obra de referência, sob pena de, ao afastar-se em demasiado do que sugere a obra original, obter-se como resultado um trabalho paralelo, em vez do intertexto. Consciente das interpretações que a obra pode comportar, o artista conserva a liberdade de adequá-la aos seus interesses quando de sua transposição, sem, no entanto, suscitar estranhamentos quanto à ocorrência do intertexto.

\footnotetext{
${ }^{10}$ Corrente teórica dos formalistas russos.
} 


\subsection{Intertextos e interdiscursos: estilização, paródia, paráfrase}

Santana classificou, quanto ao intertexto, três elementos distintos, separados conforme o grau de desvio que estabelecem a um original:

\footnotetext{
Trabalhemos com a noção de desvio. Consideremos que os jogos estabelecidos nas relações intra e extratextuais são desvios maiores ou menores em relação a um original. Desse modo, a paráfrase surge como um desvio mínimo, a estilização como um desvio tolerável, e a paródia como um desvio total. (idem, 2003, p. 38).
}

Se o artista empreende um trabalho sério de análise do texto que pretende estilizar, alcança, conforme qualquer um desses termos, a referência ao texto original, restando estabelecidas as relações entre um ou mais textos. Conservada a percepção da referência, a distinção que se estabelece agora, se dá na observação dos níveis de desvios ao se comparar os dois trabalhos. Ou seja, na paráfrase, o artista inclui em sua obra elementos de uma obra anterior, sem modificá-los. Na estilização, o artista modifica alguns elementos da obra anterior, mantendo-se, entretanto, o vínculo e a estrutura. Na paródia, o artista propõe a subversão do sentido e da estrutura do texto original mantendo com ele relações de referência que costumam produzir humor e crítica. Conforme Santana (ibidem, p. 41): “de uma outra maneira ainda poderíamos dizer: a diferença entre esses termos está em que a paródia deforma, a paráfrase conforma e a estilização reforma."

A estilização seria, portanto, uma técnica geral, enquanto a paródia e a paráfrase seriam os efeitos particulares. A estilização é o artifício usado na produção da obra, e a paródia e a paráfrase, o resultado. Na transposição de linguagens artísticas, ocorre uma estilização produzida com recursos estéticos distintos dos da obra anterior. Essa estilização, ou seja, essa transposição de linguagens pode causar efeitos como paródia ou como paráfrase.

A apropriação moderna, segundo Santana (2003), chegou à literatura por meio das artes plásticas, com a colagem (confecção de objetos artísticos a partir de elementos do cotidiano), os ready-made de Marcel Duchamp (deslocamento de objetos industriais e reapresentação em galerias e museus como obras de arte), e ainda com o Dadaísmo e a popart, que também se utilizam da técnica do deslocamento e da reunião de elementos do cotidiano, em especial os de consumo. A apropriação, na arte, consiste em apoderar-se da obra alheia e, então, transformá-la conforme diferentes concepções. Embora haja semelhanças entre apropriação, paráfrase e paródia, Santana destaca que, 
na paráfrase a apropriação é fraca. [...] o texto original é que deglute o texto segundo, deixando nele sua marca: a paráfrase é quase uma não-autoria. Já a apropriação, propriamente dita, por se situar não no conjunto das similaridades, mas no conjunto das diferenças, é uma variante da paródia e tem uma força crítica É uma interferência no circuito. Não pretende re-produzir, mas produzir algo diferente. (ibidem, p. 48).

Ora, as produções literárias e artísticas resultam de um processo criativo que se alimenta das experiências estéticas vividas por seus criadores. Essas experiências, de forma patente ou latente, tenderão a se projetar nas suas produções. A apropriação é, portanto, interpretação do mundo objetivo e também do mundo da arte.

$\mathrm{O}$ artista, consciente, ou inconscientemente, interpreta, significa e ressignifica a produção de seus antepassados e de seus contemporâneos. As produções a que ele tem acesso influenciam as suas, pois é justamente por meio da arte que ele manifesta suas ideias, pensamentos e opiniões sobre o mundo que o cerca. E esse mundo pode ser real ou imaginário, enfim, o artista é sensível aos acontecimentos (reais) e às criações (imaginárias) de sua época e de épocas anteriores. Como Jauss assinalou:

\footnotetext{
A história da literatura é um processo de recepção e produção estética que se realiza na atualização dos textos literários por parte do leitor que os recebe, do escritor que se faz novamente produtor, e do crítico, que sobre eles reflete. (idem, 1994, p. 25).
}

A recepção do conto de Guimarães Rosa tende a influenciar outras produções, neste caso, ela se atualiza na canção de Caetano Veloso que, por sua vez, atualiza-se na instalação artística de Guto Lacaz. Embora sejam independentes, cada uma dessas linguagens artísticas comunicam-se entre si e com seus receptores, por meio da organização de seus elementos. A arte ultrapassa tempo e espaço, atualiza-se das mais diferentes formas, a partir da recepção e, finalmente, insere-se numa comunidade.

A libertação da arte do domínio do tempo e do espaço é o que enseja a ela alcançar diferentes culturas, atravessar os séculos e, por meio de seus símbolos, estabelecer uma via de comunicação com o Outro. Os intertextos surgem como diálogo entre as obras e induzem o leitor a percorrer o labirinto de símbolos, signos e índices da arte.

$\mathrm{O}$ artista, como Perseu, ao adentrar o labirinto das produções artísticas, traz consigo o fio condutor que orienta a passagem. O receptor que o acompanha não se perde, encontra-se, ao fim do percurso, enriquecido pela experiência estética do labirinto formado pelos intertextos e interdiscursos da arte. 
Sendo assim, as interferências entre os textos e as artes, antes de confundir ou subtrair o atributo de originalidade da obra, acrescenta uma diferença que conduz à ampliação dos seus significados e conceitos. Desta forma, uma obra conduz à outra obra e também a novas formas de percepção do tema, num processo contínuo e dinâmico, impulsionando com maior rapidez e acessibilidade a produção e recepção das obras. O trabalho do leitor e, principalmente, do analista literário, se torna, assim, cada vez mais investigativo; como conclui Cyntrão: "analisar um texto literário, hoje, significa, portanto, desvendar, no mosaico de códigos que o compõem, as relações subjacentes do ser humano com o mundo (real ou imaginário) que o envolve".

O artista busca elementos do mundo e os transforma, pela via da arte, em produção estética, permeada dos símbolos, signos e índices formados ao longo da trajetória humana e incorporados às diferentes culturas. Entretanto, o artista não sofre influência apenas do mundo real, mas também do mundo imaginário, criado por ele mesmo ou por outros artistas, e que vem à tona no momento de sua produção. Nesse sentido, é possível verificar que

\begin{abstract}
em muitos casos o termo intertextualidade pode perfeitamente ser muito limitado para descrever esse processo; talvez interdiscursividade seja um termo mais preciso para as formas coletivas de discurso das quais o pós-moderno se alimenta parodicamente: a literatura, as artes visuais, a história a biografia, a teoria, a filosofia, a psicanálise, a sociologia - a lista poderia continuar. (HUTCHEON, 1991, p. 169/170).
\end{abstract}

O processo de transposição do conto de Guimarães Rosa para a canção de Caetano e desta para a instalação artística de Guto Lacaz vai além da intertextualidade, pois o que ocorre é justamente a atualização do discurso no tempo, no espaço, mas também na linguagem.

A terceira margem, discurso introduzido por Guimarães Rosa em seu conto é incorporado às outras artes, formando assim, uma intertextualidade. É o caso da canção, em que a apropriação do discurso pelo texto poético se dá pela manipulação da palavra. A instalação artística, embora não se utilize de texto como recurso estético principal, transforma o discurso escrito em discurso visual. As criações pós-modernas vão assim se alimentando das experiências humanas nas mais diversas áreas, construindo e disseminando discursos não só com palavras, mas de muitas outras formas expressivas. $\mathrm{O}$ texto produz o discurso e, a partir daí, ele se abre às interdiscursividades, que podem ser verificadas em diferentes meios, utilizando-se de outros tipos de recursos, não só os linguísticos, para a sua comunicação. 
A interdiscursividade é uma das características da pós-modernidade. Devido à velocidade das mudanças tecnológicas dos últimos anos, é comum a sensação de que o mundo está acelerado e de que é necessário às pessoas movimentarem-se cada vez mais rápido a fim de acompanhar esse desenvolvimento. Fixar-se, hoje, significa estagnar-se e, então, tornar-se retrógado. Conforme constatou Bauman:

\footnotetext{
Um artista ou escritor contemporâneo está numa situação de um filósofo: o texto que escreve e a obra que apresenta não estão, em princípio, norteados por regras estabelecidas e eles não podem sujeitar-se a um determinado julgamento pela aplicação de categorias conhecidas. São essas regras e essas categorias que a obra e o texto procura. (idem, 1998, p. 133).
}

Diante desse conflito, o artista pós-moderno responde com uma arte dinâmica, autônoma, afinal, não se prende a regras preestabelecidas, ao contrário, a arte é elaborada livremente e daí apresenta suas regras.

Por outro lado, as facilidades de uso, divulgação e reprodução de imagens e textos, banalizam, de certa forma, a obra de arte. Conforme observado por Walter Benjamim, faz com que se perca a "aura" artística. Além disso, é preciso hoje, chamar a atenção de um público acomodado, habituado com as facilidades de acesso rápido que a tecnologia fornece, mesmo em detrimento da experiência estética que o original e o evento em tempo real proporcionam. Portanto, o artista invadiu espaços e impôs, nos últimos anos, as suas produções. A arte pós-moderna vai, assim, se identificando como uma arte de interferência, impacto e interação.

A instalação artística de Guto Lacaz oferece nova ótica em relação ao tema do conto e da canção. Ao se deparar, em espaço público, com uma grande plataforma que abriga duas canoas, e perceber a possibilidade de uma terceira, refletida num espelho, o espectador é chamado à apreciação artística. Dessa forma, ainda que ele não costume frequentar os espaços reservados à apreciação das artes visuais, termina por apreciá-la nos espaços cotidianamente frequentados por ele. Porém, a arte pós-moderna não proporciona ao espectador apenas a apreciação, ela o convida também à participação. Faz-se necessário que o espectador se posicione adequadamente diante da obra para perceber, no espelho, a terceira canoa e seu nome (cujo significado se revela no reflexo). Nesse caso, cabe ao espectador aceitar ou não o convite. A reação do público diante da interatividade que a obra proporciona e as reflexões que ela fomenta, acrescentam à obra valores de originalidade e criatividade.

A arte pós-moderna, portanto, não apenas se impõe, ao se expor e interferir nos espaços mais improváveis, como também, muitas vezes, exige a participação do público. $\mathrm{O}$ 
que se presencia é uma arte inovadora, diferente e, por isso mesmo, discriminada, mal aceita, mas que vem conquistando espaços, apresentando-se e conduzindo um público apressado a tomar parte de sua expressividade, a interagir e, finalmente, usufruir da experiência estética que ela proporciona.

A respeito do aspecto revolucionário da arte contemporânea, Bauman observa que: "a obra do artista pós-moderno é um esforço heroico de dar voz ao inefável e uma conformação tangível ao invisível”. (ibidem, p. 133-134). O esforço do artista é, então, de fazer falar a imagem, cantar a prosa, materializar a poesia. Os intertextos, interdiscursos, estilizações e apropriações apresentam-se, então, como recursos que o artista utiliza a fim de dar conta do empreendimento.

O intertexto nas três obras aqui analisadas é bem evidente, principalmente devido ao título. O interdiscurso, porém permite observar desvios, seja devido à transposição de linguagens, seja devido à abertura de perspectivas que cada autor agregou ao conteúdo. A imagem que Rosa transmite é a de um espaço transcendental e isso foi mantido nas três obras. No conto, esse espaço é representado pela imagem de "Nosso pai" em meio ao rio, dentro de sua canoa. Na canção, esse espaço é definido como a "risca terceira", produzida pelo movimento da canoa em meio ao rio. E, na instalação, o reflexo de Cajuína no espelho transmite a imagem da terceira margem transcendental.

Contudo, cada obra prioriza um aspecto do discurso. Enquanto no conto a ótica do filho é priorizada, devido ao foco narrativo em primeira pessoa, na canção é introduzido o discurso do Outro, mesclando-se primeira e terceira pessoa:

\footnotetext{
Meio a meio o rio ri

Por entre as árvores da vida

O rio riu, ri

Por sob a risca da canoa

$\mathrm{O}$ riu viu, vi

O que ninguém jamais olvida

Ouvi, ouvi, ouvi

A voz das águas
}

A decisão de "Nosso pai" em abandonar a família e ir morar numa canoa, no rio, é um feito extraordinário que foge à compreensão do narrador, e o silêncio do canoeiro não ajuda, ao contrário, confunde, angustia e enche de culpa o filho: "De que era que eu tinha tanta, tanta culpa? Se o meu pai, sempre fazendo ausência: e o rio-rio-rio, o rio - pondo perpétuo" (ROSA, 2001, p. 84). Nesse momento, o narrador utiliza o pronome possessivo em primeira pessoa (meu pai), assumindo sozinho a culpa, a responsabilidade talvez, pelo discurso que 
profere sobre o cancionista silencioso. Para dar conta desse conflito, a canção destaca a antítese palavra versus silêncio:

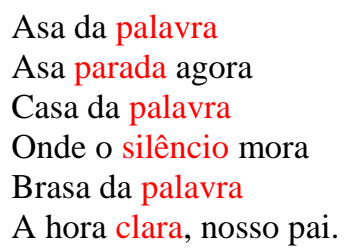

A palavra acende uma brasa, mas não ilumina o silêncio de "Nosso pai". O cancioneiro interpreta assim a angústia do filho, que gostaria de reconstituir, por meio do discurso, o feito inefável do pai. A estrofe também forma um trocadilho interno se, mudando de perspectiva, o leitor relacionar as repetições do substantivo "palavra" aos adjetivos "parada", "silêncio""11 e "clara". Enfim, a canção também forma com a instalação artística o interdiscurso da mudança de perspectiva que possibilita enxergar o Outro.

A instalação, por sua vez, não enfatiza palavra ou silêncio, nem a voz do $\mathrm{Eu}$, nem a voz do Outro, mas o assombro visual. A instalação é, portanto, constatação. A forma como cada espectador reage ao assombro da constatação visual que ela oferece pode ficar muda ou expressa em sons e palavras. Enfim, palavra, silêncio, assombro, estão presentes nas três obras, o que diferencia é a maneira como o discurso sobre cada um desses elementos é destacado.

Em se tratando das relações intra e extratextuais, verifica-se que canção e instalação artística empreenderam uma apropriação do conto de Guimarães Rosa, formando intertexto e interdiscursos a partir da temática proposta por Rosa. Os desvios ocasionados pela transposição de linguagens afetam o modo como o discurso é transmitido, exigindo, então, uma tradução intersemiótica do texto. A tradução intersemiótica, por sua vez, exige interpretação de signos e a elaboração de um sistema de sinais que fomente o intercâmbio entre as obras. Os recursos estéticos de cada linguagem artística proporcionam aos autores a elaboração desses sistemas, com os quais é possível transmitir, de maneira peculiar, a mensagem.

Os recursos poéticos e sonoros da canção foram empregados com habilidade pelos cancionistas na transposição do discurso narrativo em canção popular. O intertexto permeia toda a obra, a partir do título. A canção mantém vínculos convergentes com o conto no

\footnotetext{
${ }^{11}$ Considerando-se a leitura usual e completa da estrofe, o vocábulo "silêncio" exerce no verso, a função de substantivo. Na mudança de perspectiva, considerando-se o verso interno, torna-se um substantivo adjetivado, pois está qualificando o termo "palavra".
} 
tocante ao discurso do filho em contraposição ao silêncio do pai, apresentando em substituição à voz do pai, as vozes da natureza. Quanto à instalação, utilizando-se de recursos visuais, mantém relação extratextual com as outras duas obras. Desvia-se do discurso sobre palavra e silêncio, pois o artista optou por levar o espectador a visualizar a terceira margem, em vez de falar dela.

A culpa que o narrador expressa de forma tão profunda e que não consegue compreender, já que foi o pai que resolveu abandonar a família, pode ser considerada conforme o sentimento humano frente ao apelo do rosto do próximo. Segundo Levinas, o rosto é aquilo que o Outro apresenta a mim, destituído das minhas especulações. O narrador não compreende a razão de sentir-se tão particularmente responsável pelo pai que o abandonou quando criança.

"Ele estava lá, sem a minha tranquilidade" (ibidem). O narrador sente-se constantemente perturbado pelo sentimento de responsabilidade que assumiu, desde quando, ainda menino, começou a levar comida ao pai. Mas qual seria o estatuto dessa responsabilidade? Uma resposta pode ser encontrada no texto de Levinas:

\begin{abstract}
Responsabilidade indeclinável, duma ordem estranha do saber; como se, de toda a eternidade, o eu fosse o primeiro chamado a esta responsabilidade; impermutável, e assim único, assim eu, refém eleito. [...] Desde toda a eternidade um homem responde por um outro. De único a único. Que ele me olhe ou não, "ele me diz respeito", devo responder por ele. Chamo rosto o que, assim, em outrem, diz respeito ao eu - me concerne - lembrando, por detrás da postura que ele exibe em seu retrato, seu abandono, seu desamparo e sua mortalidade e seu apelo à minha antiga responsabilidade, como se ele fosse único no mundo - amado. Apelo do rosto do próximo que, em sua urgência ética, adia ou apaga as obrigações que o eu interpelado deve a si próprio e onde a preocupação pela morte de outrem pode, no entanto, ser mais importante para o eu do que a preocupação consigo. [...]. Possibilidade do sacrifício como sentido da aventura humana! Algo de significativo (sensé), apesar da morte, mesmo sem ressurreição! Sentido último de um amor sem concupiscência e dum eu que não é mais abominável. (idem, 2004, p. 291).
\end{abstract}

Em consequência desse sentimento, o narrador não se casou e, quando toda a família se mudou, decidiu ficar. Ele se sacrificou pelo pai porque, intuitivamente, sabia que "Meu pai" também havia se sacrificado por ele. Não obstante, o sacrifício de "Nosso pai" era de outra ordem, mais amplo e em prol de muitos filhos. As considerações acerca desse sacrifício serão feitas no final do terceiro capítulo. 


\title{
3. Terceira margem: a interseção
}

\author{
"É preciso construir enquanto tal esse lugar de coexistência de todos os pontos a \\ partir dos quais se definem tantos pontos de vista diferentes, e concorrentes, e que \\ não é outro que não o campo (artístico, literário, filosófico)" 12 \\ "Eu ando meio febril, repleto, com um enxame de personagens que pedem pouso em \\ papel. É coisa dura e já me assusta antes de pôr o pé no caminho penoso que já \\ conheço". 13
}

A identidade do sujeito vai se configurando no tempo, conforme seus relacionamentos com os outros. Mas esse relacionamento, necessário, não é sem conflitos. Neste ponto do estudo, o espectador que havia se posicionado diante do rio, fixo à primeira margem, encontra-se agora bem distante da terra firme. As produções artísticas e literárias, como uma enchente, o arrastaram para dentro do rio. E ele se debate em meio ao turbilhão de águas, tentando atingir a segunda margem.

O percurso é longo, o caminho, que deverá ser percorrido a nado, é penoso, conforme já antecipa aquele que o percorreu tantas vezes e que agora serve de guia ao espectador: Guimarães Rosa. Guiados por ele, os espectadores das obras aqui analisadas, já molharam os pés no rio, alguns foram arrastados pela enchente de palavras, outros se lançaram espontaneamente, movidos pela força de atração intensa do canto das sereias:

\begin{abstract}
As sereias: consta que elas cantavam, mas de uma maneira que não satisfazia, que apenas dava a entender a em que direção se abriam as verdadeiras fontes e a verdadeira felicidade do canto. Entretanto, por seus cantos imperfeitos, que não passavam de um canto ainda por vir, conduziam os navegantes em direção àquele espaço onde o cantar começava de fato. Elas não os enganavam, portanto, levavamnos realmente ao objetivo. Mas, tendo atingido o objetivo, o que acontecia, o que era esse lugar? Era aquele onde só se podia desaparecer [...] (BLANCHOT, 2005. p. 3).
\end{abstract}

Oxalá fosse possível ao espectador permanecer incólume na sua primeira margem. Viveria na totalidade, não precisaria se lançar ao infinito. Mas, uma vez que o Outro não se origina das configurações do Mesmo, não pode ser encontrado ali, na primeira margem. Tampouco este encontro se dará na segunda, pois, conforme Levinas (2004), a distância entre o Eu e o Outro é infinita. Esse encontro, transcendente, só pode ocorrer em um lugar neutro.

Portanto, embora o Outro esteja lá, na segunda margem do rio, jamais é alcançado ali, pois, ao aportar na segunda margem, invertem-se as posições, e ela se transforma imediatamente na primeira. $\mathrm{O}$ Eu que se atira no rio com o intuito de alcançar a segunda margem perseguirá indefinidamente esse objetivo sem jamais atingi-lo, pois se trata de uma

\footnotetext{
${ }^{12}$ Pierre Bourdie - As Regras da Arte, 1996, p. 220

${ }^{13}$ Guimarães Rosa, em entrevista a Günter Lorenz - "Diálogo com Guimarães Rosa".
} 
busca estéril, como a do canto das sereias. Consequentemente, para o encontro do ego com o alter faz-se necessário a abertura de uma terceira margem, um encontro a meio caminho, que possibilite, enfim, a interseção. Não obstante,

\begin{abstract}
em que se enriqueceria o acontecimento se eu fundir-me com o outro: se de dois, passamos a um? Que vantagem teria eu em que o outro se funda comigo? Ele só verá e só saberá o que eu mesmo vejo e sei, ele somente reproduzirá em si mesmo o que em minha vida continua sem solução; é preferível que ele permaneça fora de mim, pois é a partir da sua posição que pode ver e saber o que, a partir da minha posição, não posso nem ver nem saber, sendo assim que ele poderá enriquecer o acontecimento da minha vida. Ao somente fundir-me com a vida do outro, limito-me a acentuar o que continua sem solução nessa vida, limito-me a duplicá-la numericamente. (BAKHTIN, 1997, p. 102/103).
\end{abstract}

A interseção aproxima e confunde, mas nela não há fusão, restam prevalecidos ambos os conjuntos. De que forma literatura e outras artes, em suas conexões e correspondências, podem favorecer maior proximidade entre o espectador e a segunda margem? O espectador, como quem recebe a obra a partir de um lugar fixo na primeira margem, é atraído pelo canto que mais se adéqua às suas aspirações. Então, cada linguagem artística executa uma função que ajuda a mover o espectador rumo à segunda margem.

A segunda margem, por sua vez, representa o Outro, toda a exterioridade, aquilo que não faz parte do Eu do espectador, e que o artista tenta reproduzir em suas obras. Literatura e outras artes convidam o espectador a sair da primeira margem em direção à segunda. No entanto, há entre essa segunda margem e o espectador um imenso e misterioso rio, cujas águas ameaçam submergi-lo. Esse rio significa a exterioridade, tudo que difere e separa o sujeito do Outro. A canoa representa os recursos estéticos que o artista utiliza para produzir suas obras, e que lhe dão suporte para se manter sobre o rio. $\mathrm{O}$ espectador assume, às vezes, a função de artista, outras vezes apenas de apreciador da arte.

Impulsionado pelas representações artísticas, o espectador é encorajado a se atirar no rio (na exterioridade), não apenas para alcançar a segunda margem, mas também para, juntos (espectador, rio e canoa), comporem a terceira. De qualquer forma, se ele permanece na primeira margem, não enseja experimentar a alteridade, torna-se sujeito idem. Se, no entanto, propõe-se a buscar a segunda (embora jamais possa alcançá-la, posto que ela é o Outro que sempre escapa) pode compor, a meio caminho rio adentro, na canoa, uma terceira margem.

Mas esse encontro a meio caminho é ilusório, transcendente. O que prevalece dessa ilusão do encontro é o fascínio capaz de impulsionar o espectador em direção à promessa de proximidade cada vez maior com algo surpreendente e revelador. Mas, "por que o fascínio? Ver supõe a distância, a decisão separadora, o poder de não estar em contato e de evitar no 
contato a confusão". (BLANCHOT, 2010, p. 23). Estar na terceira margem pressupõe, portanto, distância. E, à distância, o fascínio de ver e ver-se visto. Porém, a distância exige renúncia ao contato. $\mathrm{O}$ contato favorece a confusão entre a primeira e a segunda margem, entre o ego e o alter. No contato o que se obtém é o alterego, o Outro submisso à autoridade do Eu, o Eu mesclado e corrompido pelo Outro.

\begin{abstract}
Portanto, se existe uma esperança de retrocesso é desviando-nos cada vez mais, mediante uma conversão da consciência que, em vez de a conduzir para o que chamamos o real e que apenas é a realidade objetiva, aquela em que nos mantemos na segurança das formas estáveis e das existências separadas, em vez de, também, a manter à sua própria superfície, no mundo das representações que nada mais são do que a duplicação dos objetos, a desvie para uma intimidade mais profunda, para o mais interior e invisível, quando já não nos preocupa fazer e agir, mas estamos livres de nós, das coisas, "abandonados, expostos sobre as montanhas do coração", mais próximos desse ponto em que o interior e o exterior se reúnem num só espaço contínuo. (ibidem, p. 147).
\end{abstract}

As representações artísticas, embora favoreçam a afirmação de identidades e promovam conscientizações libertadoras, não são suficientes para proporcionar ao sujeito uma intimidade mais profunda consigo mesmo e com os outros. A consciência mantém o sujeito na sua interioridade ou na superfície do mundo das representações. O sujeito formula o exterior a partir de si mesmo ou das representações, passiva ou criticamente. Não obstante, Blanchot propõe mais do que isso, ele propõe a conversão dessa consciência, em consciência livre, capaz de reunir o interior e o exterior num só espaço contínuo. Essa é a esperança de uma terceira margem. Arte e literatura, em suas representações, apenas apontam para esse ponto, como o canto das sereias que atrai os navegantes.

Os navegantes (produtores e apreciadores das artes e da literatura) são compelidos a empreender uma jornada em direção à verdadeira fonte do sublime, do belo, da felicidade. Do mesmo modo, pretendem favorecer a aproximação e a revelação do Outro. Entretanto, o que de fato, ocorre é o caminho penoso em direção à promessa do que está por vir. Bravos navegantes se lançam a nado nesse caminho e vão se infiltrando cada vez mais a fundo, porém sem nunca chegar a destino algum. O único destino a que se chega é à margem terceira, onde, porém, só se pode desaparecer. Lugar neutro, onde não se pode ser o Mesmo e nem se pode ser o Outro.

A terceira margem, espaço de intersubjetividades, onde ao Outro é dado existir em sua exterioridade desconcertante, faz desaparecer o artista. Esse espaço onde, simultaneamente, a intimidade incômoda do Eu é preservada, denuncia o artista. Mas, que espaço seria esse, como é possível imaginá-lo? Em palavras teóricas, ele poderia ser assim descrito: 


\begin{abstract}
Não poderia dar-se o caso e existir um ponto em que o espaço fosse, ao mesmo tempo, intimidade e exterioridade, um espaço que, do lado de fora, já fosse intimidade espiritual, uma intimidade que, em nós, seria a realidade do exterior, de tal modo que aí estaríamos em nós do lado de fora, na intimidade e amplitude íntima desse exterior? (ibidem, p. 145).
\end{abstract}

Em letra poética, poderia ser transmitido por esses versos: "Margem da palavra/Entre as escuras duas/ Margens da palavra.” E em imagem, por que não? A imagem do próprio espectador num espelho que também transmite a imagem do Outro, inclusive a de Cajuína. As palavras também produzem imagens e, então, "formada, a imagem tenta aprisionar a alteridade estranha das coisas e dos homens" (BOSI, 1977, p. 14). Mas a alteridade escapa, e o empreendimento de capturá-la e aprisioná-la numa obra é o trabalho interminável de todo artista.

\title{
3.1. Recursos estéticos: mímesis, mito e representação efeito
}

Em Mímesis: desafio ao pensamento, Luís Costa Lima (2000) investiga um meio de estabelecer vínculos entre sujeito e representação diverso daqueles que vêm sendo explorados desde o século XIX, e que já eram então questionados. Para isso, utiliza-se de uma concepção de sujeito "não solar, unitário, imperial." Significa, portanto, o rompimento com a ideia de um sujeito que é considerado dono de suas representações, que exerce sobre elas a sua autoridade e que tem legitimidade quase que exclusiva para falar delas. Costa Lima sugere, então, a ideia de sujeito fraturado, ou seja, uma concepção de sujeito que, por possuir maior plasticidade, está mais apto a responder às variadas experiências do mundo. O escritor, sujeito fraturado, não retém, dessa maneira, a amplitude de sua obra, pois esta se alia ao horizonte de expectativas do leitor para, finalmente, se completar.

O acontecimento extraordinário que o narrador tenta relatar no conto A terceira margem do rio: "aquilo que não havia, acontecia" (ROSA, 2001, p. 80), pode ser empregado, por analogia, aos aspectos concernentes aos estudos da representação, inclusive aos aspectos míticos. Entretanto, a fim de se verificar de que modo as obras aqui analisadas revelam as definições e os efeitos atribuídos pelos estudiosos às representações artísticas, faz-se necessário revisar certas nuanças dos conceitos de representação ao longo da História.

Os estudos sobre representação, seus conceitos e acepções têm passado por diversas considerações ao longo do tempo, procurando se adaptar às tendências e ao pensamento de cada época. Trata-se, portanto, de um fenômeno complexo, flexível e que comporta 
possibilidades de tratamento diferenciado, a depender dos objetivos e reflexões que se queira obter a partir de seus mecanismos e atuações.

Platão e Aristóteles já se posicionavam sobre o tema e tinham a respeito dele algumas ideias divergentes. Na República, Platão se refere à representação como imitação da natureza, desconsiderando nas artes o seu valor de originalidade, relacionando a mímesis a um "jogo infantil” de aparências (Rep., X, 598a). Representar é, pois, para Platão mais um distanciamento da verdade do que sua proximidade, e isto induziria o homem ao erro. $\mathrm{O}$ artista é como o canoeiro errante que rema em sua canoa sem jamais fixar destino. A arte perturba o espectador, que aprecia a paisagem formada pelo canoeiro, pelo rio e pela canoa, mas não consegue formular considerações exatas sobre aquilo que vê.

Aristóteles, por sua vez, defendia a imitação como própria da natureza humana e propiciadora de prazer e de contemplação diverso daqueles que o real inspira (Poét., IV, 13). Argumenta, em favor das artes, que as representações são fonte de conhecimento e satisfação, fomentam reflexão, exercitam o discernimento. $\mathrm{O}$ narrador, no conto, tenta representar em palavras o gesto de "Nosso pai", e seu desespero reside justamente em não conseguir realizar tal empreendimento, o que talvez lhe auxiliasse a compreender o fato, ou pelo menos, lhe trouxesse alguma satisfação. Embora Platão e Aristóteles conservassem a respeito da mímesis a ideia de simulação da realidade, divergiam no que concerne à apropriação que se faz dela. Afinal, simular a realidade por meio de representações artísticas pode conduzir a erros de verossimilhança, mas pode também auxiliar na assimilação de realidades e situações complexas.

Os conceitos de representação também sofrem influência das sociedades e dos contextos a que são inseridos. Na Idade Média, representar significava assemelhar-se a algo, estar no lugar do representado. Esta primazia da semelhança nos estudos da arte e da representação se estendeu até o fim do século XVI, de acordo com Michel Foulcaut (2000, p. 24): "foi ela [a semelhança] que organizou o jogo dos símbolos, permitiu o conhecimento das coisas visíveis e invisíveis, guiou a arte de representá-las”. Assim era possível restringir os avanços da mímesis, estipulando para ela um lugar, o da semelhança, de onde seria mais fácil controlar as suas projeções sociais.

No período clássico, a semelhança, vista como um sistema que aproxima as linguagens propõe a interação dos signos, com suas infinitas possibilidades em gerar e reconhecer semelhanças. Aquele que representa é também representado, sugerindo, assim, a autonomia da representação em relação ao autor e a seus referentes. Entretanto, estabelecer definições ao arcabouço formado pelo infinito sistema de semelhanças, tornou-se tarefa para sempre 
inconclusa. Surge, então, a necessidade de se estabelecer uma ordem, por meio dos signos, que possibilitassem sua análise.

“A partir da idade clássica, o signo é a representatividade da representação enquanto ela é representável” (ibidem, p 89). Essa análise ocorre em função das correspondências entre significante e significado na assimilação dos signos, realizável por meio da representação. A representação é, portanto, o espaço apropriado pelos signos, o qual norteará o pensamento moderno.

Contudo, o afastamento que se deu entre representação e semelhança provocou também, desde a idade clássica até a idade moderna, o enfraquecimento da mímesis. Enquanto as teorias sobre representação se abasteciam nos sistemas de signos, ela se recolhia no espaço da imitação, da semelhança. Ou seja, os conceitos de representação avançaram a partir dos estudos sobre sistemas de signos, enquanto os estudos sobre mímesis a restringiam a conceitos atrelados à imitação. Entretanto, autores contemporâneos, como Luiz Costa Lima, Paul Ricoeur e Renè Girard propõem o resgate da mímesis, não somente em seus atributos de imitação da natureza, como também terminam por ensejar considerações sobre sua força mágica e ritualística. A magia se encontra na forma como a mímesis implica tanto semelhanças quanto diferenças. Na sutil transposição que se dá num processo constante da semelhança à diferença, se realiza o ritual.

"Sob a equivalência, estava contida uma diferença" (COSTA LIMA, 2000, p. 297). E, nos termos Aristotélicos, o prazer de se identificar as diferenças. Prazer que o sujeito fraturado busca em função de alcançar conhecimento. É então, por meio da fratura do sujeito e também pela consideração do jogo indefinido entre diferença e semelhança, que Costa Lima pretende o resgate da mímesis. O autor aborda o fenômeno da representação como efeito forma mais subjetiva, tratada pelas ciências humanas, especialmente pelas artes, e seu relacionamento com as concepções de mímesis. Representar, nos termos propostos por Costa Lima não é o mesmo que assemelhar a algo.

Ao provocar efeitos no receptor, a representação instiga novas produções e, assim, é possível afirmar que representar nada tem a ver com imitação, pois assume o status de novidade, uma vez que é produzida por um sujeito fraturado, a partir de suas impressões do mundo e de suas convivências sociais, políticas, espirituais, enfim, de suas experiências de vida. "A produção apenas começa na obra; a representação que ela suscitará manterá seu caráter produtivo, portanto potencialmente divergente" (ibidem, p. 277). A arte contemporânea, em seus intertextos e apropriações de produções anteriores, demonstra bem 
esse caráter produtivo da representação-efeito. Além disso, a arte contemporânea enseja, constantemente, espaços de interatividade entre obra e espectador.

Todavia, essa interação entre obra e espectador, antes de ser característica das vanguardas, é, conforme Luís Costa Lima, "uma produção específica da mímesis". (ibidem, p. 160). Em Mímesis: desafio ao pensamento, Costa Lima explora as análises do quadro La Tempestà, de Giorgione (c. 1477-1510) feitas por Louis Marin, para exemplificar as ocorrências da representação-efeito. Após uma descrição detalhada do quadro, Costa Lima se detém em duas figuras que o compõem: um soldado e uma mulher semidesnuda que amamenta uma criança. Cada uma das figuras ocupa as margens opostas de um rio. Costa Lima, então, direciona suas considerações sobre o olhar das duas figuras e o que ele implica quanto à concepção de representação-efeito.

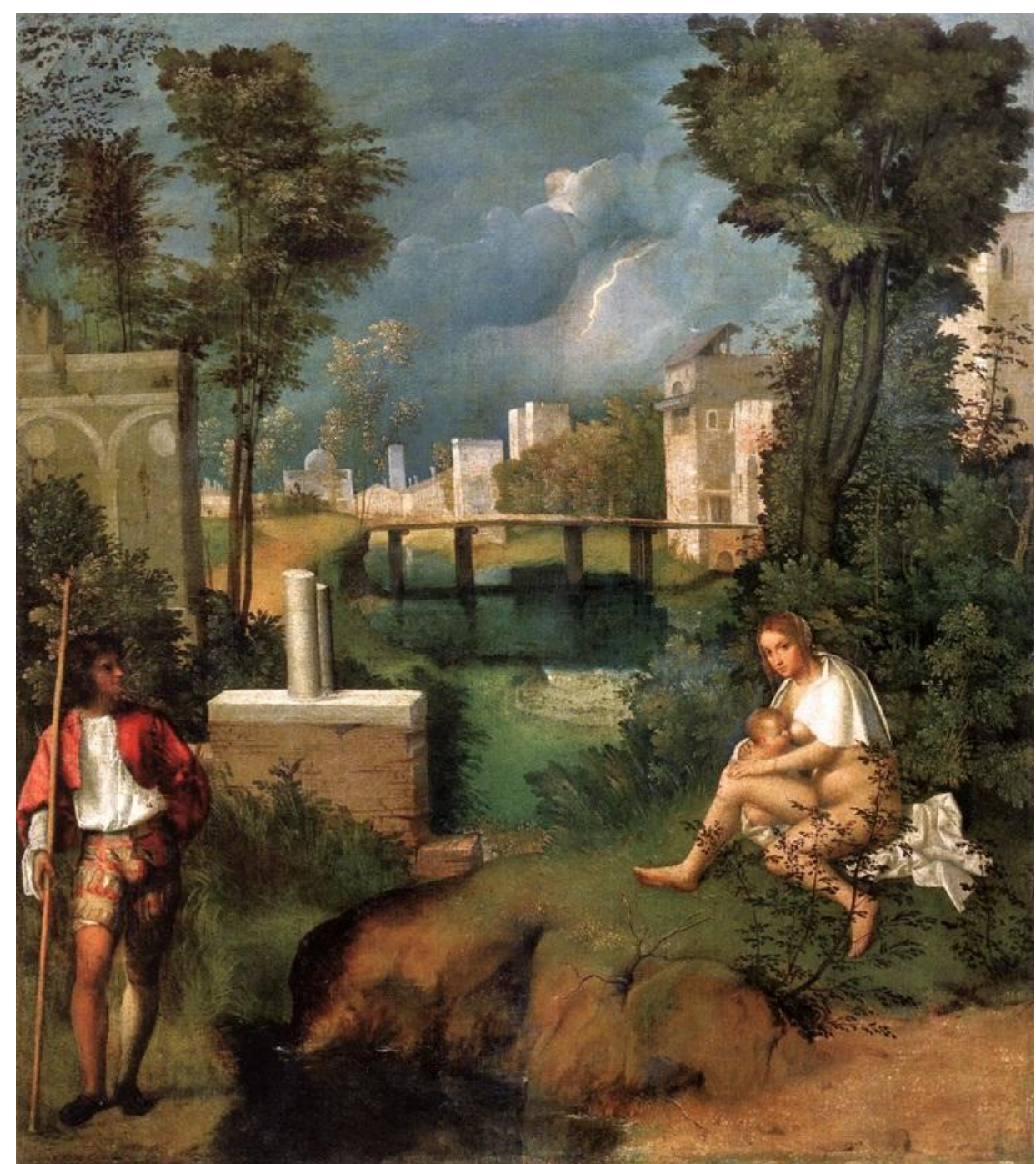

Fig. 5 - A tempestade (Giorgione) 
Conforme as análises de Marin, existe no quadro um jogo de olhares a três, não obstante sejam visíveis apenas duas figuras com seus olhares em duas direções distintas, ou seja, o soldado que monta guarda e olha em direção ao promontório da outra margem, e a mulher que olha para fora do quadro. $\mathrm{O}$ soldado olha a mulher, sem ser visto por ela. $\mathrm{O}$ espectador olha o soldado sem ser visto por ele. A mulher olha o espectador, embora ele não faça parte da representação do quadro, e não se vê vista pelo soldado. Portanto, há sempre um terceiro invisível. Há sempre um Outro oculto.

Uma vez que a mulher é considerada o próprio quadro e figura de reflexão para aqueles que a olham (soldado e espectador), Costa Lima conclui que o quadro comporta em si o seu efeito. E, então, levanta um questionamento sobre como se considerar o efeito sem levar em conta aquele que o sente. Enfim, o quadro demonstra o efeito de uma cena sobre um determinado espectador (inserido no próprio quadro), mas também desvela o espectador que há fora do quadro, através do olhar da mulher. O sujeito que outrora apenas contemplava o quadro, de repente é convidado a ver-se visto pelo quadro. Isso só pode ser feito quando ele renuncia a sua condição de espectador e assume a condição de quadro, objeto de contemplação.

Além disso, segundo Costa Lima (2000, p.120), “não há representação sem sujeito, é certo, porque as propriedades do agente humano necessariamente se incorporam à sua observação". No entanto, sendo a representação originária do sujeito e, sendo o sujeito influenciado pela sociedade, parece que assim surge um impasse que pretende reduzir os estudos de representação, sobretudo a mímesis, como cópia do mundo. Kant, com sua teoria a respeito do sujeito fraturado, é requisitado por Costa Lima para a ampliação dos estudos sobre representação, já que remete a um sujeito flexível, que se adapta às mais diversificadas experiências e situações, recompondo-se também a partir delas. Um sujeito que já deixou a primeira margem e conhece as turbulências das águas do rio que é a exterioridade.

Esse sujeito fraturado é capaz de sentir o efeito que o quadro desperta como espectador e também de se sentir quadro em uma mudança de ótica. Dessa forma, a representação-efeito, juntamente com o sujeito fraturado, no papel daquele que produz, mas não se apropria das suas representações, são os que se encontram na terceira margem do rio. Afinal, não se trata mais de uma representação imutável, presa às intenções do autor, mas daquela que é flexível, que atravessa espaços e tempos, provocando efeitos.

$\mathrm{O}$ resgate da mímesis nos estudos de Costa Lima pressupõe também o seu desdobramento em duas formas: mímesis da produção e mímesis da representação. A mímesis da representação pressupõe a representação-efeito que, embora ressalte mais o efeito causado 
no receptor que o reconhecimento fiel de um objeto, gera confusão, pois não consegue desvendar quanto desse efeito provém das referências do mundo. Para reconhecer estas referências é necessário que se conheça o ritual em que sua presença se concretiza. $\mathrm{O}$ horizonte de expectativas do receptor pode orientar a decodificação deste ritual, porém sem nada determinar para além da sua própria recepção.

Quanto à mímesis da produção, importa que o sujeito seja abolido ou neutralizado. Isto não significa que Costa Lima esteja se contradizendo quando afirma que não existe representação sem sujeito, mas como ele mesmo elucida: "a tal ponto o produtor se confunde com o produzido e a tal ponto este se confunde com a linguagem transformadora de suas referências que o sujeito é anexado à pura representação. A representação a se cumprir no leitor terá, pois, que se ajustar àquele desaparecimento" (ibidem, p. 322). O sujeito atinge o ponto indicado pelo canto das sereias, e onde só é possível o seu desaparecimento.

Ocorre, então, o fenômeno de transcendência da mímesis, pois ela suplanta a representação-efeito. Por meio de sua própria linguagem, e com o auxílio da memória do espectador que a atualiza, a mímesis transforma os pontos de contato das referências (do mundo) com que a obra é recebida em menções constituídas em si mesma. Em outras palavras, a mímesis da produção exige do espectador mais do que supõe seu "horizonte de expectativas". Enquanto o espectador tenta identificar nas produções o seu "horizonte de expectativas", ele ainda não deixou a primeira margem do rio.

O desejo de representar e de ser representado se concretiza na mímesis, porém, segundo Costa Lima, “a mímesis não se origina da vontade de se assemelhar a algo, a alguém ou a alguma forma de conduta sua, mas sim da demanda de constituir uma identidade subjetiva para quem a empreende" (ibidem, p. 323). Então, o que se busca na mímesis? Buscase identificação de semelhanças, reconhecimento de diferenças. Ás vezes, a mímesis é requerida para preencher os espaços abertos pelo desconhecido. Neste sentido, em seu jogo de equivalências, ela preenche os espaços e auxilia a compreensão do mundo.

O narrador do conto A terceira margem do rio passa toda a sua vida buscando resgatar o pai que um dia entrou na canoa e partiu sem ter ido à parte alguma. Depara-se com a inquietante sensação de dualidade que a imagem do pai na canoa provoca: a da presença e ausência simultâneas. Confuso, o filho não pode fazer mais do que observar, pois o silêncio de "Nosso pai" aliado ao gesto inusitado de sua partida, não comporta explicação. Tampouco o filho consegue compor uma representação satisfatória do pai, o que dificulta o seu resgate por meio da mímesis. 
Se ele identificasse no pai semelhanças suas e também reconhecesse as diferenças; se ao menos pudesse realizar esse jogo dúbio a partir de alguma situação real equivalente à do canoeiro na terceira margem do rio, mas não há com que se comparar. A situação é demasiadamente estranha, inusitada, representá-la requer muito esforço e habilidade. Durante muito tempo, o narrador não consegue mimetizar o acontecimento, não consegue trazer, por meio de nenhum processo mimético, a experiência transcendental do canoeiro.

De acordo com estudos de Ricoeur (1985), é possível alcançar melhor compreensão por meio da narrativa do que pela explicação histórica. Considere-se, então, que na ausência de um discurso que sintetizasse, de algum modo, o gesto de "Nosso pai", e na ausência de alguma situação equivalente à qual o narrador pudesse ancorar suas representações, ele intenta recompor a situação por meio do relato. Assim, ao relatar o acontecimento, ele também busca garantir ao pai alguma representação. Entretanto, sente-se frustrado em seu intento, percebe que a linguagem não é capaz de realizar o resgate que ele almejava.

O cancionista interpreta essa peculiaridade da linguagem por meio da metáfora da palavra como água. Forma-se a imagem da palavra como algo que escorre, se esparrama, se infiltra e não se pode simplesmente dominar seus percursos e incursões. A estrofe ainda forma um trocadilho interno que atribui à linguagem (palavra) as virtudes de silenciar e enrijecer:

\footnotetext{
Água da palavra

Água calada pura

Água da palavra

Água de Rosa dura
}

Portanto, o narrador não encontra na linguagem a representação que talvez pudesse resgatar, para si e para os outros, a vida de "Nosso pai". Em haver permanecido na primeira margem, sem jamais ter ousado lançar-se ao rio, rumo ao espaço neutro onde, quem sabe, poderia encontrar-se com "Nosso pai”, não foi capaz de alcançá-lo. A narrativa que constrói é feita, então de "tristes palavras".

Porém, toda narrativa é mimética e, sendo assim, não pode conter a verdade de uma vida. A mímesis tem no mundo a sua referência, mas não a sua verdade. Por tomar do mundo referências e, de modo peculiar, devolvê-las transformadas, a mímesis se mostra como uma espécie de magia. A duplicidade que ela produz em relação ao mundo desafia o pensamento, e, por isso mesmo, instiga a curiosidade. O narrador desejava resgatar o pai de sua decisão em permanecer no rio, porém, em sua narrativa, tudo o que conseguiu foi perpetuar a imagem de 
"Nosso pai" no rio: "Sou homem de tristes palavras. De que era que eu tinha tanta, tanta culpa? Se o meu pai, sempre fazendo ausência: e o rio-rio-rio, o rio - pondo perpétuo". (ROSA, 2001, p.84).

As representações comportam justamente o sentido dúbio de presença e ausência. $\mathrm{O}$ narrador almeja conceder ao pai algum tipo de representação, pois não consegue aceitar o seu desaparecimento. No entanto, insiste em identificar o pai a partir da margem que ele deixou, em vez de acolhê-lo conforme a margem que ele escolheu. Consequentemente, em sua tentativa de representar "Nosso pai", o narrador parece identificar mais ausências do que presença. Ele sente fracassar mais um projeto de resgate de "Nosso pai" da terceira margem que o envolveu. A canoa, o rio e até a sua narrativa perpetuam aquele acontecimento extraordinário que ninguém poderia esquecer nem explicar. Assim, esse acontecimento vai se tornando um mito.

De acordo com Barthes (2009) tudo pode ser mito, e o mito não é um objeto, um conceito, uma ideia, é comunicação, mensagem, significação. Para que algo se torne mito, basta que se fale dele, ressignificando-o, pois o mito é uma fala. "Esta fala é uma mensagem. Pode, portanto, não ser oral; pode ser formada por escritas ou representações: o discurso assim como a fotografia, o cinema, a reportagem, o esporte, os espetáculos, a publicidade, tudo isso pode servir de apoio à fala mítica" (ibidem, p. 199/200).

As representações são bastante propensas a se tornarem mitos, sejam elas compostas por palavras ou por imagens. Nem todas as representações se tornarão mitos, mas somente aquelas que forem escolhidas pela História, pois "é a História que transforma o real em discurso; é ela e somente ela que comanda a vida e a morte da linguagem mítica" (ibidem, p. 200). Desde que fosse construído sobre "Nosso pai" um discurso (oral, escrito ou imagético), e esse discurso se prolongasse no tempo, sendo escolhido pela História, "Nosso pai” seria, então, um mito.

Ideologias são constantemente inseridas nas representações, que são um meio eficaz de introdução e circulação delas na sociedade, afetando os sujeitos. Apesar disso, as representações que se tornam mito ou que, de alguma forma, servem a ele, são aquelas que, ao longo da História, se revestiram do discurso apropriado ao valor e ao sujeito a que os mitos se destinam. O silêncio de "Nosso pai" dificulta a sua transformação em mito, porém não impede que sejam construídos discursos sobre ele.

Não obstante, o mito se constrói a partir de uma cadeia semiológica preexistente. Isto para que seja facilmente assimilado. O relato da história de "Nosso pai" deu início à cadeia semiológica sobre a qual pode ser construído o mito. Canção, instalação artística, teatro, 
cinema e telenovela fazem parte dessa cadeia. $\mathrm{O}$ mito parte de um conceito e o repete por meio de formas variadas que são os significantes, mas o conceito limita-se a reapresentar-se, enquanto o significante é ilimitado. O mito é uma fala roubada e restituída. Rouba-se o conceito e restitui-se uma significação. Essa significação nunca é completamente arbitrária, tem sempre ao menos uma parte motivada. Há, no entanto, algum conceito referente a "Nosso pai" no relato do filho? Quem dizem ser o canoeiro da terceira margem do rio?

As formas do mito são motivadas pelo conceito, porém não representa o conceito em sua totalidade. No conto, o narrador se absteve de formular sobre "Nosso pai" um conceito. Tampouco esse conceito foi inserido por meio da canção ou da instalação artística. Todavia, com o passar do tempo, surge em sua cadeia semiológica, o "Velho do rio" da telenovela Pantanal. Quem dizem ser, na telenovela, o "Velho do rio"? Um homem espectral que vive nos rios e que aparece para ajudar as pessoas que são picadas de cobra. Dizem também que ele se transforma em sucuri. Eis aí o conceito, a definição que faltava para transformar a história de "Nosso pai" em mito.

O mito recebe um real histórico e restitui ao mundo uma imagem natural desse real. Daí que, para o leitor do mito, a reação é de aceitação, posto que o mito substitui uma realidade por outra, incompleta, porém com aparências de clareza. "O leitor vive o mito como uma história simultaneamente verdadeira e irreal" (BARTHES, 2009, p. 220). Embora o conto não seja uma história real e, portanto, não se encaixe nessas formulações a respeito do mito, a realidade interna da ficção serve de apoio quanto às transformações que uma narrativa pode comportar ao longo do tempo e na História. Na telenovela, o "Velho do rio" tornou-se mito porque na composição de sua intriga, prevaleceu a dualidade entre realidade e imaginação popular.

Haja vista que tudo pode ser mito, e que o mito é uma fala roubada, a mímesis constantemente fornece a ele uma fala. Entretanto, como a fala roubada pelo mito nunca é restituída exatamente a mesma, a representação que antes era mímesis, torna-se, por meio da agregação histórica de um discurso, mito. Assume, pois motivação e, não raro, motivação política, ideológica. No conto, os familiares de "Nosso pai" tentam evitar que sobre ele seja construído o discurso do louco e, então, decidem não falar mais a respeito dele. Contudo, não o podem esquecer. O filho resolve compor o seu relato e, apesar dos escassos elementos de que dispõe, tenta elaborar para ele uma narrativa, uma mímesis da representação da qual fala Luís Costa Lima. Mas a mímesis pode fornecer ao mito uma fala, então "Nosso pai" pode ser transformado no "Velho do rio" e até mesmo em sucuri. 
Enquanto mímesis, a representação pode causar desconfortos, gerar polêmicas. Entretanto, se, historicamente repetida, uma forma de representação pode se tornar um estereótipo e daí, basta a sua naturalização para que se transforme em mito. Segundo Barthes, “o mito não nega as coisas; a sua função é, pelo contrário, falar delas; simplesmente, purificaas, inocenta-as, fundamenta-as em natureza e em eternidade, dá-lhes uma clareza, não de explicação, mas de constatação" (ibidem, p.235). A representação despolitizada, sintetizada e artificial, massivamente repetida, pode alcançar a força de um mito, com o qual não se mantêm relações de verdade, mas sim de utilização. Servirá aos interesses de alguns, surgirá oportunamente em determinadas situações e desaparecerá em outras.

Portanto, mímesis, representação e mito implicam poder. Quem representa hoje como nos primórdios, experimenta uma espécie de poder, de domínio. Ser representado ou omitido também interfere na forma como a sociedade percebe um grupo. Mas não apenas isso, a maneira como um grupo é representado tem o poder de sugerir julgamentos, propor discussões, transformar pensamentos, perpetuar injustiças.

No conto, o narrador compõe um relato para representar o pai. Intenta, assim, protegêlo de representações falsas que pudessem denegrir a sua imagem. Então, o que ele busca é resgatar a identidade perdida de "Nosso pai", aquela de "homem ordeiro, cumpridor", porque não pode compreender e nem aceitar o homem da canoa, sobre o qual falam as pessoas. Elas poderiam representar de forma muito negativa o pai que o narrador tem em elevada consideração. A culpa que o narrador carrega se divide num paradoxo: é culpado por não representar "Nosso pai" e também por representá-lo, do mesmo modo que "Nosso pai" era presença e ausência simultâneas.

Platão propunha que fossem proibidas as representações, a começar pela poesia, justamente por considerá-las irresistivelmente atrativas, apesar de nunca conseguirem se adequar à realidade. A fim de solucionar esse impasse, deve-se subtrair às representações o compromisso com o real, como propõe Luiz Costa Lima. Isso, no entanto, não impede as construções de mitos. De acordo com Barthes, "só o grau zero poderia resistir ao mito" (ibidem, p. 224). O grau zero em linguística é o presente do indicativo.

Em toda a história da humanidade a arte manteve ligações com elementos mitológicos religiosos, místicos, sagrados. Diversas culturas cultivam a crença de que o sagrado se manifesta por meio da arte e, consequentemente, assumem diante dela postura diferenciada, ora de respeito e reverência, ora de estranheza e rejeição. Proibições e restrições quanto à criação e uso de algumas formas de arte também são comuns, não apenas devido à referência expressa na bíblica de restrição às imagens, mas também por causa do conteúdo de certas 
representações artísticas. A arte e a literatura são consideradas, portanto, via de acesso ao sagrado, mas também ao profano. Sobre a figura do artista também recaem as contradições entre o sagrado e o profano, o divino e o demoníaco.

$\mathrm{Na}$ arquitetura é possível identificar diversas construções que mantém estreita ligação com o sagrado, desde os primórdios. Os monumentos de Stonehenge, por exemplo, têm sido largamente considerados em seus aspectos ritualísticos; as pirâmides e os mausoléus são exemplos de arquitetura colocada a serviço das relações do homem com o sagrado, assim como as pinturas e esculturas egípcias funerárias. Entre os gregos encontram-se templos repletos de representações de deuses e deusas. A arquitetura oriental revela o uso da geometria não somente em seus traços estruturais, mas também com significados simbólicos que objetivam a comunicação com o sagrado. Nas mais diversas culturas e em diversos períodos, a arquitetura tem sido usada como ponte para o sagrado. Templos e habitações são erigidos e tornados "eixo do mundo", conforme Eliade (1979, p. 37): "as sociedades arcaicas e tradicionais concebem o mundo em seu redor como um microcosmos. Nos limites deste mundo fechado, começa o domínio do desconhecido, do não formado.”

Nas artes cênicas, há a tragédia que, na Grécia antiga, era vista como arte dramática em que se destaca a sacralidade do espetáculo. Entre os cristãos de todo o mundo, as representações da Paixão de Cristo, que se repetem anualmente na páscoa, são consideradas em seus aspectos sagrados. Alguns tipos de dança são constantemente realizadas com o intuito de evocar o sagrado, assim como a produção de sons e músicas que são executados com o mesmo intuito.

Quer seja estudando a arte funerária da antiga civilização egípcia, quer seja a arte representativa dos deuses e mitos da antiguidade clássica, ou na pintura sagrada japonesa, encontram-se sempre ligações religiosas, místicas e sagradas na arte desde a pré-história até os tempos modernos. Quanto à presença ou ausência do sagrado na poesia Zumthor destaca que,

entre um "ritual" no sentido religioso estrito e um poema oral poderíamos avançar, dizendo que a diferença é apenas de presença ou ausência do sagrado. No entanto, a experiência que tenho das culturas nas quais subsistem tradições orais vivas, levame a pensar que essa diferença não é percebida por aqueles partícipes dessas culturas. No caso do ritual propriamente dito, incontestavelmente, um discurso poético é pronunciado, mas esse discurso se dirige, talvez, por intermédio dos participantes do rito, aos poderes sagrados que regem a vida; no caso da poesia, o discurso se dirige à comunidade humana: diferença de finalidade, de destinatário; mas não da própria natureza discursiva.” (idem, 2007, p. 45). 
Portanto, a própria natureza discursiva é ritualística e costuma evocar certa sacralidade quando o discurso é proferido oralmente. A sacralidade manifestada na arte e na literatura contemporânea pode ser analisada sob o ponto de vista da arte sacra, da arte religiosa e da arte profana. Embora pareça estar completamente desvinculada de aspectos sagrados, a arte profana frequentemente contém símbolos sagrados. Às vezes se dirigindo ao sagrado, às vezes se dirigindo à comunidade humana, arte e literatura costumam formar imagens e discursos que evocam certa sacralidade latente ou patente.

No conto, o narrador menciona as crendices, consideradas por ele "sem senso", que as pessoas da cidade formulavam tentando explicar a atitude de "Nosso pai": "Só as falsas conversas, sem senso, como por ocasião, no começo, na vinda das primeiras cheias do rio, com chuvas que não estiavam, todos temeram o fim-do-mundo, diziam: que nosso pai fosse o avisado que nem Noé, que, por tanto, a canoa ele tinha antecipado.” (ROSA, 2001, p. 84). Verifica-se aí a presença de um discurso que, embora considerado "sem senso", insere na narrativa as especulações humanas acerca da sacralidade do gesto de "Nosso pai".

"Nosso pai", ao longo do tempo, começa a se despersonalizar. Aos poucos ele vai deixando de ser visto como pessoa e, em substituição, vai assumindo, na ótica dos moradores da cidade, atributos de personagem mitológico. O que intentam é construir para ele uma narrativa, fazer de seu empreendimento uma lenda, um mito. Indiscriminadamente, é prática comum atribuir às representações artísticas características mágico-ritual e, às vezes, sagradas. "Nosso pai" vai se tornando mito, uma representação artística que, ora é considerada sagrada, ora é considerada profana.

Quando um objeto artístico ou uma representação ganham significados de imanência do sagrado, o mesmo ocorre com o artista que os criou. Ou seja, desde que o gesto de "Nosso pai" seja vinculado, por meio da afirmação de um discurso, a um ritual sagrado, também ele se torna um ser místico, transcendente, como no mito do "Velho do rio." E, em algumas culturas, estabelece-se a figura do artista consagrado, alguém que se dedica inteiramente à elaboração de arte sacra.

Quando, então, a obra e o artista tornam-se estreitamente vinculados ao sagrado, passam a dedicar-se inteiramente a ele. Isso ocorre no caso das artes sacras e do artista consagrado. Primeira expressão artística no Brasil colonial, a arte sacra diferencia-se das outras formas de arte místico-religiosas pela sua função de culto. A arte sacra, portanto, é produzida com objetivo definido: o de servir a rituais litúrgicos. É uma arte que, mais do que comportar elementos estéticos e próprios da linguagem artística, deve se adequar à cerimônia litúrgica para a qual foi produzida. 
Muitas construções na arquitetura e, ligadas a ela, outras formas de artes visuais como a escultura e a pintura, são produzidas especificamente com a finalidade de servir ao culto. Música, dança e encenações também são produzidas com essa finalidade e, portanto, é possível afirmar que, em suas diversas manifestações, a arte tem sido empregada com função específica de culto. Não apenas nas religiões judaico-cristãs, mas também no budismo, hinduísmo, islamismo e em muitas outras, existem formas de arte sacra.

Uma das expressões da arte sacra que mais chamam a atenção devido ao simbolismo que evoca, são os ícones. Aos ícones é conferida não apenas função de culto e reverência, mas também a de elevação do espírito humano. São considerados fonte de oração e de inspiração divina. No entanto, um ícone é revestido de signos religiosos e sagrados, próprios para despertar no homem a elevação de sentimentos ao contemplá-lo. Intrigante, porém, é o fato de que diversas outras formas de arte, desde os tempos mais remotos até os atuais, tendem a despertar sentimentos numinosos ${ }^{14}$, de maneira arbitrária e ainda que dissociadas do culto. Às imagens e às representações em geral, são atribuídos constantemente aspectos sobrenaturais, mas não apenas isso, elas trazem também símbolos da sacralidade arcaica, mesmo na sociedade moderna.

Vestígios da aura sobrenatural da mímesis entre os povos primitivos são constantemente registrados por historiadores e paleontólogos. A mímesis desperta no homem o sentimento de sagrado e do sobrenatural devido, em parte, a seu atributo de duplicidade. Segundo Girard (1998, p.196): “o duplo e o monstro são apenas um [...] Todos os monstros têm tendência a se desdobrar, e não há duplo que não encerre uma monstruosidade secreta".

É inegável que o narrador do conto e "Nosso pai" possam formar um duplo. O filho representa o papel do homem "ordeiro, cumpridor, positivo" (predicados anteriormente atribuídos ao pai), fixo em sua primeira margem. O pai representa o papel do monstro, do estranho que mora numa terceira margem, dentro do rio. Eles são o desdobramento de uma mesma identidade, sendo que uma delas, a do canoeiro, o filho passa toda a vida tentando negar. Ele sabe que deveria assumir a sua parte monstro, ou seja, a do canoeiro, mas prefere manter-se fixo à segurança da primeira margem. Ao tentar reproduzir a história de "Nosso pai" por meio do relato, o narrador vai sendo tomado pelo sentimento de culpa, do que ele nem sabe. Na verdade, ele é tomado de consciência sobre a dualidade existente entre ele e o pai, embora não saiba ainda o que deveria ou poderia fazer a esse respeito. A representação

\footnotetext{
${ }^{14}$ Termo proposto pelo filósofo Rudolf Otto para definir um estado de espírito de fascínio e terror frente ao mistério e ao sagrado.
} 
narrativa que ele faz de "Nosso pai", apresenta a ele o seu duplo, o seu Outro, que ele se negou a enxergar durante todos aquele anos.

As representações artísticas que visam a duplicar a realidade sensível trazem, consequentemente, o signo da monstruosidade. Mas não apenas isso, elas tendem a se tornarem manifestações sagradas ou mágicas. É o caso dos vodus, que, ao duplicarem a imagem de um adversário, acreditam-se exercer o domínio sobre o corpo do adversário. É como se, na imagem, ficasse retida a alma do ser duplicado. A fotografia, por muito tempo, foi vista com certo receio e muitas pessoas sentiam-se desconfortáveis ao deixarem-se fotografar. Sobre isso Jung comenta:

\begin{abstract}
As pinturas paleolíticas das cavernas consistem, quase inteiramente, de figuras de animais cujos movimentos e posturas foram observados na natureza e reproduzidos com grande habilidade artística. Há, no entanto, muitos detalhes que mostram ter havido a intenção de fazer das figuras mais do que simples reproduções. [...] Estas imagens sugerem uma espécie de magia [...] O animal pintado tem a função de um double, isto é, de um substituto. Com o seu massacre simbólico os caçadores antecipam e asseguram a morte do animal verdadeiro. [...] o que acontece com a pintura deve acontecer com o original. A explicação psicológica subjacente é uma forte identificação entre o ser vivo e sua imagem, que é considerada a alma daquele ser. (idem, 1964, p. 235).
\end{abstract}

Representações de cenas teatrais de morte, doença, possessões diabólicas, sempre suscitaram especulações quanto ao destino daquele que se propõe a representar tais situações, como se, a partir dali, sua imagem ficasse para sempre acoplada àquela situação que foi por ele representada. Um exemplo recente é o caso do filme Batman, o cavaleiro das trevas (2008), em que a produção do filme foi envolvida em tragédias sucessivas, inclusive a morte, por intoxicação acidental por remédios prescritos, do ator Heath Ledger, alguns meses após a representação do antagonista Coringa. Devido a isso, especulações a respeito de maldições e de consagrações sobrenaturais foram levantadas em torno da produção do filme.

Outro exemplo recente no cinema é o filme O Cisne Negro (2011), em que o diretor Darren Aronofsky enfatiza a aderência total da artista ao personagem, numa integração tão completa que se torna difícil, para a cena, e também para o público, distinguir o plano do real do plano da fantasia. Contudo, para que essa adesão fosse possível, fez-se necessário à personagem experimentar na pele algumas situações propícias para que seu duplo viesse à tona. No conto em questão, não há aderência do narrador ao seu duplo, ao contrário, ele foge à situação que o levaria a confrontar-se com ele.

O narrador não consegue separar a sua própria identidade daquela de "Nosso pai", porém o que ele intenta é que "Nosso pai" se assemelhe a ele, que permaneça fixo à primeira margem, como ele próprio permaneceu. O narrador não deseja formar um duplo com o pai, 
isso o apavora. Ele sabe que "Nosso pai" havia se modificado e que agora se assemelhava a um bicho, um monstro. Essa é, pelo menos, a imagem que ele faz de "Nosso pai" após longos anos na canoa. Entretanto, "as imagens, os símbolos, os mitos, não são criações irresponsáveis da psiquê; eles respondem a uma necessidade e preenchem uma função: pôr a nu as mais secretas modalidades do ser." (ELIADE, 1979, p.13). Aquele monstro que o narrador imagina viver na canoa, no rio, bem pode ser uma modalidade secreta da natureza do filho, mas isso ele não gostaria de deixar transparecer.

Ao ser criado um duplo, o homem experimenta uma espécie de poder sobrenatural. Sente-se ganhar atributos divinos de criador, porém não consegue dominar o duplo, no sentido de que, psicologicamente, sente dificuldades em manter, separar e desfazer os duplos. Ocorre, assim, a indistinção, ou seja, o duplo confunde-se com o seu referente, gerando especulações em torno da violência. Afinal, segundo Girard (1998), a violência surge justamente da dissolução das diferenças.

René Girard, antropólogo e filósofo francês elaborou a tese de que as instituições humanas possuem uma origem ritual que busca, por meio do sacrifício de uma vítima, conter a violência subjacente de seus componentes. Há, nos seres humanos, uma violência potencial em decorrência do desejo mimético. Girard denomina desejo mimético a situação em que um sujeito imita o desejo do outro. Afinal, é no relacionamento com o outro que o sujeito constitui a sua própria identidade, contudo, por não saber o que desejar, o sujeito escolhe imitar um modelo sobre o qual projeta os seus desejos. O sujeito imita o desejo do outro. $\mathrm{O}$ objeto não é desejado por seus atributos, mas porque foi escolhido por alguém cujo modelo se pretende imitar. Enfim, ocorre que dois sujeitos (discípulo e mestre) desejam o mesmo objeto, tornando-se rivais. Assim nascem as rivalidades no interior de uma família ou comunidade, o que pode provocar o desencadeamento de uma violência generalizada. Para conter a violência intestina, é preciso descarregar sobre uma vítima adequada todas as tensões que se encontram em erupção naquela sociedade.

O narrador desejaria ser como o pai, mas o afastamento de "Nosso pai" do convívio familiar trava a identificação, impede os mecanismos do desejo mimético que gera rivalidades. Entretanto, embora o objeto de desejo (ser como o pai) tenha sido afastado, o conflito gerado pelo desejo permanece, e termina por ocasionar a formação do duplo. $\mathrm{O}$ duplo, considerado uma monstruosidade, é a vítima coletiva por excelência. A fim de se preservar a comunidade das suas propensões violentas é necessário que haja a culpabilização e sacrifício de uma vítima, em especial o duplo monstruoso. 
A partir da constatação de que um duplo estava sendo formado entre pai e filho e, levando-se em consideração a teoria da crise sacrificial de René Girard, é possível interpretar a atitude de "Nosso pai" como um sacrifício que ele próprio se infringiu em favor da comunidade. Segundo Girard (ibidem, p. 69): “a ordem, a paz e a fecundidade baseiam-se nas diferenças culturais. Não são as diferenças, mas sim o seu desaparecimento que provoca a rivalidade demente, a luta extrema entre os homens de uma mesma família ou de uma mesma sociedade." Portanto, os sujeitos que formavam a mesmidade na primeira margem do rio estavam todos ameaçados por uma crise sacrificial iminente, uma vez que não eram aceitas as diferenças.

"Nosso pai" torna-se, então, espontaneamente, uma vítima expiatória. Ele reúne em si todos os requisitos propostos por Girard em relação à escolha da vítima: aparentemente é um homem comum da comunidade (a vítima não deve ser alguém de destaque, para não incitar a vingança, ), mas também guarda diferenças que o tornam apartado de todos, principalmente por ser quieto (a vítima não é violenta, nem deve estar relacionada aos conflitos geradores da violência): "do que eu mesmo me alembro, ele não figurava mais estúrdio nem mais triste do que os outros, conhecidos nossos. Só quieto”. (ROSA, 2001, p. 79). Ele não é bom nem mal, apenas ordeiro, cumpridor, positivo. Seu sacrifício consiste em ter de se afastar do convívio familiar e social. Assim, ele se contrapõe à mesmidade da primeira margem e, para o resto da vida, torna-se o diferente, o monstro. A transformação dessa história em mito é o desdobramento natural da ordem surgida após a crise sacrificial:

\footnotetext{
O monstruoso está presente em toda mitologia. Conclui-se daí que a mitologia fala constantemente da crise sacrificial, mas somente para mascará-la. É possível supor que os mitos jorrem de crises sacrificiais, e que eles constituam sua transfiguração retrospectiva, sua releitura à luz da ordem cultural surgida desta crise. (GIRARD, 1998, p.87).
}

Num momento de crise naquela comunidade, quando esteve ameaçada devido a fortes chuvas, a figura de "Nosso pai" ganha atributos sagrados e proféticos. Ele passa a ser visto como o herói que poderia salvar a todos. Há, então, a inversão do papel da vítima: o louco se torna o herói. Como louco ou doente contagioso, o seu afastamento da comunidade é um alívio, pois ele carrega consigo os perigos iminentes que poderia afligi-la. Mas, como vítima expiatória, o seu afastamento acarreta também a sua santificação e de toda a comunidade.

A paz e a harmonia que ocorrem após o sacrifício da vítima expiatória, no entanto, dura apenas um período, até que surja uma nova crise. Mas ao se manter nas proximidades da comunidade, "Nosso pai" atualiza o ritual de banimento que fez dele vítima expiatória, 
transformando o seu sacrifício expiatório em sacrifício ritual que mantém por mais tempo a harmonia entre os habitantes.

Entretanto, quando a vítima sacrificial já não funciona como contentora da violência, ocorre nova crise sacrificial e a sociedade recomeça a dar vazão aos seus desejos de violência. Faz-se necessário, então, a escolha de uma nova vítima. Conforme a tese de Girard, para se conter o desencadeamento dos mecanismos da violência generalizada numa sociedade, recorrem-se à substituição sacrificial, quando se dá o deslocamento da culpa, e uma vítima inocente é culpabilizada por todos os males da sociedade, devendo, portanto, ser sacrificada. Esse é um mecanismo inconsciente que visa proteger um grupo maior da violência, oferecendo a ela uma única vítima inocente no lugar dos culpados (punir os culpados detona um processo de vingança em série que gera mais violência).

No conto, o narrador pressente-se como vítima expiatória inocente, mas que deverá ser sacrificada quando a atualização do sacrifício de "Nosso pai" deixar de funcionar como expiação das culpas daquela comunidade: "Sou o culpado do que nem sei, de dor em aberto, no meu foro. Soubesse - se as coisas fossem outras. E fui tomando ideia." (ROSA, 2001, p. 84). Da mesma forma que o pai, ele deverá oferecer-se como vítima expiatória, a uma comunidade que, embora desconheça tal mecanismo, se vale dele para a perpetuação da harmonia intestina. $\mathrm{O}$ narrador atende perfeitamente ao princípio da substituição sacrificial proposta por Girard:

O princípio da substituição sacrificial baseia-se na semelhança entre as vítimas atuais e as vítimas potenciais, e essa condição pode ser perfeitamente preenchida, quando, nos dois casos, trata-se de seres humanos. $\mathrm{O}$ fato de que algumas sociedades tenham sistematizado a imolação de certas categorias de seres humanos com o objetivo de proteger as outras categorias não tem nada de surpreendente. (idem, 1998 , p. 25).

Como se pode perceber, há também nos meandros da culpa, o sentimento de ter sido poupado, protegido, porque alguém assumiu uma responsabilidade no lugar dos outros. O narrador experimenta a culpa em duas vias paralelas: pela responsabilidade de filho que julga estar negligenciando o pai, e de ser humano que, por questões éticas, compartilha de responsabilidade uns com os outros. Uma terceira via perpassa as outras duas: não ter conseguido separar a sua própria identidade daquela do pai, o que poderia interromper o ciclo da substituição que se iniciava. De qualquer modo, 
responsabilidade por mim, sem de imediato me encontrar, por minha condição de refém responsável por sua própria responsabilidade? Ser Eu é sempre ter uma responsabilidade a mais. [...] Só eu é que posso, sem crueldade, ser designado como vítima. O Eu é aquele que, antes de toda decisão, é eleito para carregar toda a responsabilidade do mundo. (LEVINAS, 2004, p. 92/93).

Então o filho que, durante toda vida, sofreu o conflito da indefinição de sua identidade, interrompida bruscamente pela partida do pai, de repente, numa última tentativa de resgate e redenção, dirige-se ao rio, chama pelo pai e propõe ocupar o lugar dele na canoa:

\footnotetext{
Eu estava muito no meu sentido. Esperei. Ao por fim, ele apareceu, aí e lá, o vulto. Estava ali, sentado à popa. Estava ali, de grito. Chamei, umas quantas vezes. E falei, o que me urgia, jurado e declarado, tive que reforçar a voz: — "Pai, o senhor está velho, já fez o seu tanto... Agora, o senhor vem, não carece mais... O senhor vem, e eu, agora mesmo, quando que seja, a ambas vontades, eu tomo o seu lugar, do senhor, na canoa!..." E, assim dizendo, meu coração bateu no compasso do mais certo. Ele me escutou. Ficou em pé. Manejou remo n'água, proava para cá, concordado. E eu tremi, profundo, de repente: porque, antes, ele tinha levantado o braço e feito um saudar de gesto - o primeiro, depois de tamanhos anos decorridos! E eu não podia... Por pavor, arrepiados os cabelos, corri, fugi, me tirei de lá, num procedimento desatinado. Porquanto que ele me pareceu vir: da parte de além. E estou pedindo, pedindo, pedindo um perdão. (ROSA, 2001, p.85).
}

Embora o narrador tenha fugido quando de sua proposta à substituição do pai na canoa, não escapa à condição de vítima expiatória substituta. Seja por meio do banimento ou da morte, ele é a vítima expiatória que carregará sobre si todos os males daquela comunidade, sendo assim, finaliza: "Mas, então, ao menos, que, no artigo da morte, peguem em mim, e me depositem também numa canoinha de nada, nessa água que não pára, de longas beiras: e, eu, rio abaixo, rio a fora, rio a dentro - o rio." (ibidem).

Após ter fugido ao sacrifício espontâneo de viver exilado na terceira margem do rio, sua última chance de redenção seria a morte. Pela morte, o narrador contemplaria, então, duas situações distintas e que lhe causam perturbação: a sua condição de vítima expiatória, e a sua neutralização como autor. Afinal, "o artista como personalidade criadora, o literato como existência de exceção, o poeta como gênio - o herói - não têm, felizmente, mais lugar mesmo em nossos mitos.” (BLANCHOT, 2010, p. 167).

\subsection{Conexões produtivas entre literatura e artes visuais}

A literatura, como produtora de conhecimento, favorece o fenômeno da mímesis da produção, de que Luís Costa Lima tratou em seus textos. Mais do que imitação, essa manifestação ganha aspectos de representação efeito, e Costa Lima passa, então, a ressaltar a condição de atividade geradora de efeitos da mímesis. Em se tratando de mímesis da 
produção, destacam-se os efeitos de uma mímesis primeira que, trazendo do mundo as suas referências, proporciona a produção de uma mímesis posterior, para a qual serve de referência.

Quanto ao fenômeno da transposição de linguagens artísticas, pode ser considerado sob o ponto de vista da mímesis da produção, e, embora seja frequente na arte contemporânea, não se trata de uma peculiaridade exclusiva dos dias atuais. São bastante comuns os interrelacionamentos nas artes e, entre as artes visuais e a literatura não é diferente, apesar de se utilizarem de recursos estéticos tão díspares. Conforme Étienne Souriau:

\footnotetext{
Nada mais evidente do que a existência de um tipo de parentesco entre as artes. Pintores, escultores, músicos, poetas, são levitas do mesmo templo. Servem se não ao mesmo deus, pelo menos a divindades congêneres (idem, 1983, p. 14).
}

Ao longo da História, as artes visuais e a literatura têm-se comunicado de tal forma, que se proporcionam inspiração reciprocamente. Nas culturas em que a escrita não está presente, as histórias são transmitidas oralmente, atravessando gerações. O registro dessas histórias pode ser encontrado em desenhos, pinturas, esculturas, tapeçarias. Também é possível observar representações visuais de mitos, lendas, poemas e canções em diferentes épocas e culturas, independentemente de haver ou não o registro escrito.

Durante séculos pintores se basearam em textos literários para compor sua arte, e as palavras dos poetas, muitas vezes, intentaram promover imagens figurativas semelhantes às de uma pintura. A arte ocidental revela nas paredes, nos tetos, nos quadros, nos conjuntos escultóricos e arquitetônicos, as inúmeras produções visuais que foram baseadas na literatura. A arte oriental, com maior concentração na tapeçaria, nas estatuetas e nos recipientes decorados também recorre à literatura, ao produzir imagens de suas histórias, lendas e mitos.

A leitura incita à formação de imagens mentais, porém tais imagens são desprovidas de materialidade. Então, muitos artistas visuais buscam materializar concretamente, por meio de recursos estéticos visuais, as imagens que o texto lhes sugere. Trata-se, no entanto, da interpretação do artista e, portanto, a imagem produzida a partir de um texto ganha as concepções e perspectivas do artista que a produziu. 


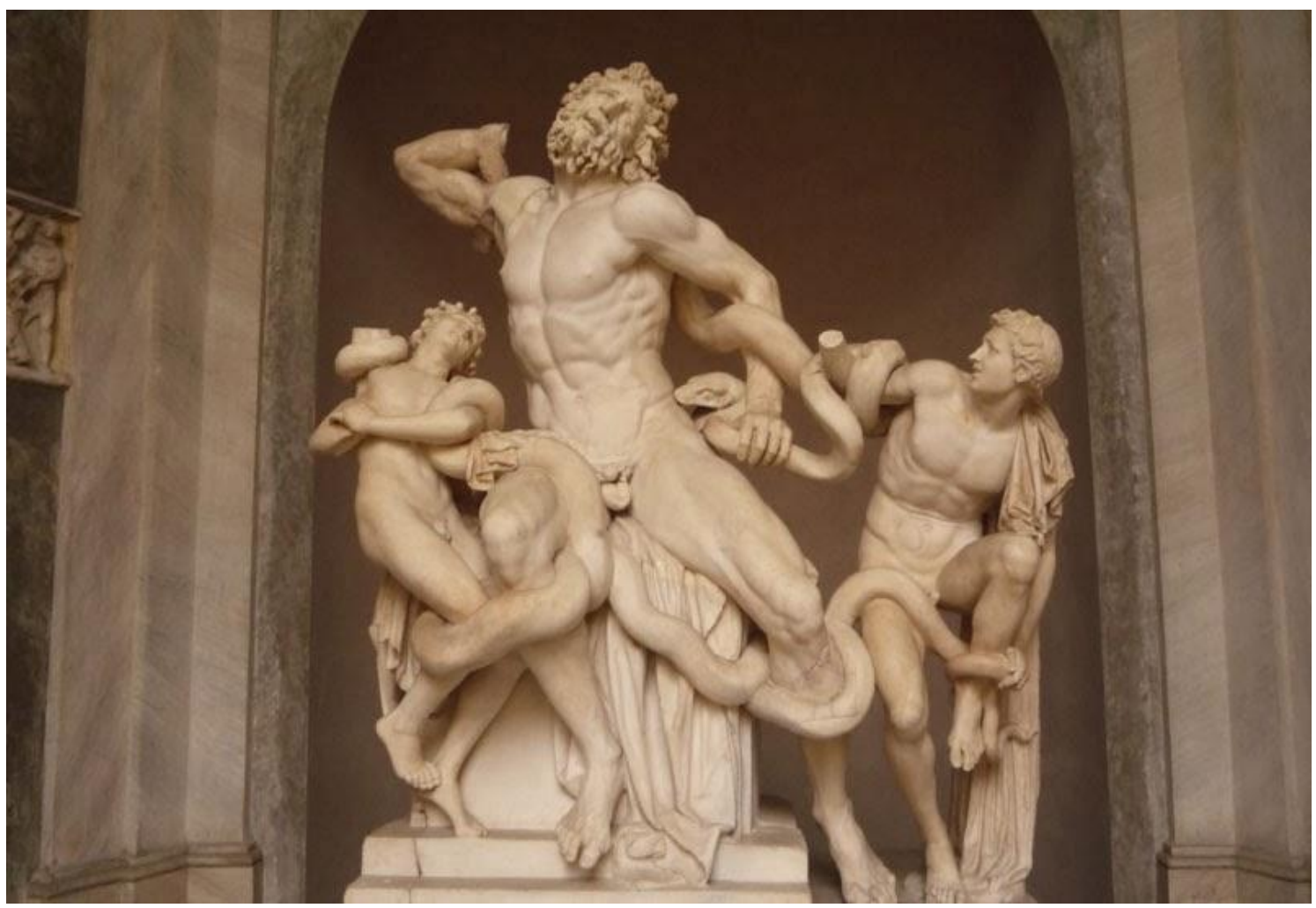

Fig. 6 - Laocoonte e seus filhos

Assim, o trabalho de transposição de uma linguagem artística a outra é, antes de tudo, uma análise interpretativa, a partir da qual o artista emprega as habilidades e os recursos inerentes a sua arte para alcançar uma nova obra. O filósofo alemão Gotthold Ephraim Lessing, em seu texto Laocoonte (1960) - referência ao grupo escultórico do período helenístico (323. A.C - 33 A.C), que representa a lenda de Laocoonte e seus filhos - analisou detalhadamente a maneira como cada artista (escritor e escultor) empenhou os recursos de sua arte para transmitir a agonia dos personagens.

Segundo a lenda, Laocoonte tenta advertir seus compatriotas troianos a respeito da armadilha do cavalo de Tróia, mas é desacreditado. Ainda assim, por vingança, a deusa Atena, favorável aos gregos, envia sobre ele e seus filhos serpentes gigantes que os mata asfixiados. O mito de Laocoonte é bem conhecido e foi explorado por Virgílio em sua obra Eneida. Lessing compara as duas formas de abordagem do mito, pela arte visual e pela literatura, e discorre sobre suas diferenças, destacando que o recurso principal da escultura é a espacialidade, enquanto o recurso principal do texto é a temporalidade.

Portanto, ao comunicar ideias e significados, as artes se valem de sistemas de signos próprios. Ou seja, a interpretação escrita de uma história transmitida oralmente, sofrerá as 
adaptações necessárias à sua transcrição escrita e, de modo ainda mais acentuado, se dará a transmutação da linguagem verbal à linguagem visual.

A temporalidade do texto exige do leitor o compromisso de ir construindo o sentido aos poucos, de ir formando, passo a passo, as imagens e sugestões apresentadas, e de incorporar a elas os seus horizontes para, então, completar o seu significado. As imagens, em contrapartida, apresentam-se de modo imediato, ainda que, depois, possa ser apreciada em detalhes dispersos. Em outras palavras,

\begin{abstract}
o modo encadeado de dizer a experiência renunciou, por certo, àquela fixidez, àquela simultaneidade, àquela forma-dada imediatamente do modo figural de concebê-la. A frase desdobra-se e rejunta-se cadeia que é antes e depois, de ainda e já não mais. Existe no tempo, no tempo subsiste. Para o emissor que a profere, para o receptor que a ouve, sílaba após sílaba. (BOSI, 1977, p. 22).
\end{abstract}

O estudo da transposição de uma obra de linguagem verbal a uma obra de linguagem não verbal deve considerar, pois, as características da imagem que se apresenta imediata e simultaneamente, e as do verbo, que exige processo e ordenamento. Construir uma imagem a partir de um texto é, pois, desmanchar a lógica de construção deste para submetê-lo à lógica de construção daquela. Tem-se, então, por consequência, o hibridismo.

Devido a sua temporalidade, a ideia geral do texto costuma ser apreendida somente ao final da leitura, entretanto, a sua tradução em imagens revela-se com o efeito de síntese ou de seleção fragmentada. O ordenamento do texto sofre as alterações impostas pela espacialidade da imagem. Ou seja, renuncia-se ao discurso abrangente que a palavra pode ofertar pela contemplação imediata de uma síntese ou de um detalhe escolhidos pelo autor da imagem.

"Mas o discurso é frágil se comparado ao efeito do ícone que seduz com a sua pura presença [...] A imagem impõe-se, arrebata. O discurso pede a quem o profere, e a quem o escuta, alguma paciência e a virtude da esperança." (ibidem, p.25). De fato, a informação visual possui maior capacidade de alcance espacial, intelectual e temporal, no sentido de que chega mais facilmente e rapidamente a lugares distantes, de difícil acesso, e também consegue alcançar letrados e iletrados, porém, ela se esbarra em suas limitações comunicativas.

A imagem serve de suporte ao texto, ilustra-o, chama a atenção para algum detalhe, mas ela não o substitui, desprovida que é da temporalidade necessária ao percurso e ao ordenamento lógico próprios do discurso escrito. Porém, apesar de sua superficialidade, a informação visual se impõe com muito mais força imediata do que a informação escrita e, assim, pode incitar a curiosidade e a investigação em relação a ela. Essa é, inclusive, uma estratégia de publicidade que usa de uma imagem impactante para conduzir o espectador a um 
determinado texto que trata do assunto de forma mais abrangente. Adiante haverá espaço para as considerações socioeducativas relacionadas à imagem e ao texto.

Mário Praz remonta as relações entre artes visuais e literatura à época pré-histórica, considerando que as ideias eram expressas por meio de figuras. Contudo, embora as interferências entre as artes possam ser observadas desde a Antiguidade, a forma como essas interferências ocorrem na arte moderna e contemporânea sofrem muitas críticas, com o argumento de que podem perder a expressão de autenticidade.

Alguns estudiosos, como Charles Baudelaire (2008), condenam este tipo de interferências entre as artes, pois defendem que a cada linguagem corresponde determinado tema, ou função. Questionava-se Baudelaire:

\footnotetext{
Será por uma fatalidade das decadências que hoje cada arte manifesta a vontade de invadir a arte vizinha e que os pintores introduzem gamas musicais na pintura, os escultores, cor na escultura, os literatos, meios plásticos na literatura, e outros artistas, aqueles dos quais vamos nos ocupar hoje, um tipo de filosofia enciclopédica na própria arte plástica? (ibidem, p. 73).
}

Considerado um precursor do modernismo, Baudelaire não acredita na supremacia de uma arte em detrimento de outra, pois considera que cada uma serve a fins e fruição estética próprios. Entretanto, em seus Escritos sobre arte, o poeta tende a definir a cada linguagem espaço e funções bem delimitados. Julga decadente o fato de uma linguagem artística expandir-se sobre aspectos de domínio específico de outra. Porém, a crítica de Baudelaire se concentra no que ele chama de arte filosófica, ou seja, uma arte que tome como objetivo racionalizar, formular deduções, o que, segundo ele, pertence ao livro. Assim como Lessing, ele formula questões de espacialidade das artes visuais, em confronto com a temporalidade do texto.

De fato, a correspondência entre as artes não deve almejar a explicação de uma obra por meio de outra, nem pretender que a obra de arte se organize didaticamente com finalidade educativa similar à do texto. Há que se compreender e analisar os limites e possibilidades de expansão de cada arte ao comunicar sentidos e significados. Embora os efeitos criados no espaço pela poesia concreta possam ser agradáveis ao olhar e oportunos ao conjunto, e também as pinturas da Paixão de Cristo, ao retratar cada cena do martírio, possam produzir efeitos visuais que acentuam o drama, as imagens que elas veiculam não abrangem a compreensão global do texto. Afinal, pela maneira em que, valendo-se de sua expressão estética, uma arte se apropria de um tema já explorado por outra e o transmite como uma obra única é que se verifica a riqueza das correspondências entre as artes. Se a poesia concreta 
almejasse apenas formar desenhos a partir de letras, ignorando o sentido do conjunto poético, pouco acrescentaria aos estudos artísticos e literários. As séries de pinturas que contam a Paixão de Cristo também enriquecem muito mais o tema pelos acréscimos e supressões ao texto bíblico.

Nesse sentido, a diversidade e miscigenação nas artes se apresentam propícias aos estudos interartes, pois tendem a ampliar as possibilidades de reflexão a esse respeito. Quanto à crítica de Baudelaire, que julgou decadente o fato de uma arte se apropriar de elementos expressivos próprios de outra, Affonso Romano de Santana faz uma consideração pertinente sobre os possíveis desdobramentos da decadência: “[...] bem pode ser o estágio normal de transformação e metamorfose. Com efeito, a arte do fim do século 19 foi conhecida como decadentista, e foi dela que surgiu a grande paródia que é a arte moderna" (idem, 2003, p. 50). A sensação de decadência faz parte do processo, e pode ser mesmo necessária a fím de se alavancar as transformações, as metamorfoses capazes de revolucionar determinadas situações.

A arte contemporânea, em seu processo de autoafirmação tende a mesclar-se com as mais diversas linguagens artísticas e não artísticas, pois a palavra de ordem atualmente é a liberdade. A criação artística tornou-se livre e, portanto, pode transformar positivamente o olhar sobre cada linguagem. Quanto às apropriações na arte contemporânea, Solange Ribeiro destaca que

através de procedimentos combinatórios, sem hierarquizá-los, apropria-se de signos de obras consagradas, e neles introduz a diferença. Assim fecundada, a pintura, por exemplo, vê prolongada sua vida, ameaçada pela explosão de novas tendências. (idem, 2007 p. 197).

No encontro entre literatura e outras artes, existem muitas possibilidades, porém o analista não deve ficar atrelado às especificidades da linguagem literária, afinal, uma vez que a linguagem é transformada, ela ganha aspectos diferentes. É inútil buscar na letra da canção fidedignidade quanto à prosa que a originou. Da mesma forma, a linguagem visual não visa traduzir em imagens a completude do discurso verbal. $\mathrm{O}$ que ocorre na transposição de linguagens é justamente um jogo de semelhanças e diferenças, próprio das representações.

As artes representativas, apesar de, a princípio, estabelecer com o espectador relações de identificação e reconhecimento de elementos da realidade objetiva, proporcionam também outro tipo de experiência estética, alcançados por meio dos recursos empregados pelo artista. $\mathrm{Na}$ literatura, a maneira como as palavras são dispostas, as figuras de linguagem e outros 
recursos linguísticos; nas artes visuais, o emprego e seleção de seus elementos expressivos: cor, forma, espaço.

Cada linguagem, com o uso de seu material, provoca efeitos diversos no espectador, conforme elucida Souriau:

\begin{abstract}
O espectador mal informado pode não se dar conta disso e ingenuamente atribuir todo o encanto da obra à cena que lhe vem à memória, quando ele entra na ficção e coloca-se diante do discurso representativo. Contempla, por exemplo, a Odalisca de Ingres ou o Outono Puvis de Chavannes, sem saber que está sob o domínio de um encantamento que, em parte, provém do canto particular e, de certa forma, melódico das linhas; ou, quando se trata de uma Vênus de Ticiano ou de uma Infanta de Velasquez, da sábia harmonia das combinações cromáticas. Ou ainda, lê um belo verso que o imerge num êxtase impreciso, sem saber ou mesmo sem querer reconhecer que um hábil arabesco de consoantes e vogais, de sílabas átonas ou acentuadas, o enfeitiçou com sua música para fazê-lo confiar mais no sentido das palavras e maravilhar-se com as imagens que lhe são oferecidas. (idem, 1983, p. 98).
\end{abstract}

Portanto, além da imagem figurativa que o artista pretendeu representar com sua arte, há ainda a imagem abstrata, provocada pelo efeito dos recursos estilísticos e estéticos de cada linguagem. Souriau destaca essa particularidade somente a respeito das artes representativas, porém, é possível julgar o mesmo em relação às artes não representativas, afinal, quando se aprecia uma obra abstrata, pode-se encontrar em suas linhas, formas e expressividade as figuras que a imaginação determinar.

O que se encontra no cerne dessa questão é a necessidade humana de dar sentido às coisas, mesmo que elas já tenham um sentido pré-determinado. A correspondência entre as artes é uma manifestação dessa necessidade. As pessoas buscam organizar, a seu modo e conforme seus interesses e perspectivas, o sentido das coisas. $\mathrm{O}$ artista tem necessidade de criar significados por meio de sua arte, logo, busca extrair o sentido de um tema do seu contexto para provocar novas abordagens desse tema em contexto diferente, numa espécie de desconstrucionismo que visa não à desautorização ou substituição de uma abordagem artística por outra, mas a flexibilização do discurso.

\title{
3.3. Instalação artística Mensagem a um general
}

Arte e literatura colocam à disposição dos indivíduos inúmeras possibilidades de desenvolvimento educativo. Uma vez que a obra de arte pode suscitar a consciência em relação a si mesmo e aos outros, torna-se elemento facilitador da percepção da alteridade, e também amplia as experiências sensoriais de conhecimento do mundo. Além disso, por meio de seus recursos estéticos proporciona expressão pessoal e canaliza sentimentos conflituosos. 
Entretanto, arte e literatura não são apenas meios de expressão, mas também podem ser fonte de conhecimento e difusão da cultura.

A constante evolução das tecnologias, que afeta todos os setores da vida, em especial o educacional e a cultura, também influencia o processo de ensino e aprendizagem. Imagens e textos ganharam novos modos de inserção na sociedade e, com isso, surge a necessidade cada vez maior de estudo e compreensão de seus atributos comunicativos. O relacionamento entre texto e imagem, na sociedade contemporânea, embora seja frequentemente difundido por meio das tecnologias, ainda é pouco explorado cientificamente. Portanto, é importante incentivar, no ambiente escolar, as questões relacionadas ao uso de imagens e textos como forma incisiva, porém potencialmente ambígua de comunicação e expressão.

Alguns questionamentos em relação à difusão, manipulação e ao uso indiscriminado das imagens pela mídia devem ser levantados, sem, no entanto, deixar-se de apresentar a importância dos efeitos positivos que a comunicação por meio das imagens pode desempenhar na educação e na absorção de mensagens. Afinal, a exploração das imagens para comunicar sentidos e significados possui, em seus desdobramentos, aspectos multifacetados que podem passar despercebidos a olhares menos atentos. Além disso, o modo como as particularidades semiológicas das imagens são exploradas e recebidas determina a assimilação do contexto e a preservação da memória.

As implicações dos efeitos que as imagens causam na memória têm sido abordadas com frequência no meio acadêmico, considerando-se o excesso de informação visual proporcionado pelo desenvolvimento tecnológico, bem como as distorções, simulações, substituições e fragmentações que as imagens tendem a difundir em oposição a um contexto mais abrangente e complexo. Não se trata de ignorar o poder de comunicação imediato da imagem, mas de refletir sobre suas limitações e funcionamentos.

No conto O Aleph, de Jorge Luís Borges (1998), o autor assim define seu embaraço diante do complexo processo de transposição da experiência visual para o relato verbal: “chego agora ao inefável centro de meu relato; começa aqui meu desespero de escritor. [...] como transmitir aos outros o infinito Aleph que minha temerosa memória mal e mal abarca?" (ibidem, p. 93). O narrador consegue relatar sem dificuldades suas impressões e posicionamentos sobre seu amigo Carlos Argentino, porém, quando se trata de descrever o Aleph - "lugar onde estão sem se confundirem, todos os lugares do orbe, vistos de todos os ângulos“ (ibidem, p. 92) - o empreendimento se demonstra inefável. Apesar disso, Borges continua o relato; busca auxílio em analogias e metáforas, mas acaba percebendo que elas não irão ajudar. Diante dessa impossibilidade de descrição verbal daquilo que os olhos viram, o 
autor decide, então, deixar o registro de "algo", ainda que seja uma centelha do Aleph e das imagens múltiplas que ele projeta. Borges, então, descreve, de forma sucessiva, aquilo que os olhos viram simultaneamente. (ibidem, p. 93). Encontram-se aí duas realidades: a das imagens, que se apresentam imediata e simultaneamente e a do verbo, que exige processo e ordenamento. Construir um discurso a partir de imagens é, pois, desmanchar a lógica de uma para submetê-la à lógica daquele. O mesmo ocorre na transposição do discurso à sua elaboração em imagens, afinal,

encontrar o equivalente visual de um projeto verbal não é simples e exige escolhas de todo tipo. Um mesmo argumento (verbal) pode dar origem a toda a espécie de representações visuais, ligadas à infinita riqueza da experiência de cada um. (JOLY, 2007, p.83)

O trabalho empregado na transposição de imagens em discurso e vice-versa, requer habilidades e conhecimento dos signos que compõem cada uma destas linguagens. Estes e outros aspectos, como, por exemplo, o uso de sistemas intersemióticos, devem ser estudados para que se possa organizar a elaboração de uma nova obra de arte a partir de um original. Ao se formar uma imagem, não se pretende encarcerar nela o sentido do objeto ao qual ela se refere. A imagem, apesar de também ser difusora de sentidos, não se dispõe a apresentar-se como solução à busca de sentido e compreensão de um objeto.

Segundo Maurice Blanchot (2011, p. 285): “A imagem de um objeto não somente não é o sentido desse objeto e não ajuda a sua compreensão, mas tende a subtraí-los na medida em que o mantém na imobilidade de uma semelhança que nada tem com que se assemelhar". Logo, não é a imagem que serve à compreensão do contexto, mas o contexto que serve à compreensão da imagem. Ou, por outro lado, a narrativa visual atrai o leitor e sintetiza o contexto, mas a narrativa escrita é que lhe orienta o sentido.

Quando a narrativa visual é tomada à parte de seu contexto e não traz suporte oral ou escrito que amplie os seus horizontes para além de sua imobilidade imagética, tende a fomentar distorções, simulações, fragmentações em relação a uma realidade mais abrangente e complexa. O que significa que a elaboração em imagens de uma obra literária não substitui a obra literária, e deve ser entendida como uma nova obra e não como complemento da obra original.

A partir da análise de uma situação concreta, e prosseguindo os estudos em relação às conexões produtivas entre literatura e outras artes, pretende-se demonstrar algumas implicações educacionais do processo de transposição de linguagens artísticas. A abordagem 
dessas implicações se orienta no sentido de que o conhecimento, disposto em diferentes ângulos e formas (imagem e texto), promove melhor desenvolvimento de uma consciência crítica e mais receptiva. No caso concreto em questão o texto literário foi o ponto de partida para a produção de outras obras (de linguagem visual), mas o processo também pode ocorrer pela via inversa, quando, partindo-se de obras de artes visuais se intenta a produção de textos literários.

A Estética da recepção enfatiza o leitor como parte fundamental da compreensão e interpretação do texto, levando-se em consideração sua posição histórica e experiências de vida. De acordo com essa teoria, cada leitor traz um horizonte de expectativas - construído a partir de suas experiências particulares - que, no momento da recepção, interfere no modo como absorvem a obra. Assim, diversos significados são atribuídos ao texto, de acordo com o horizonte de expectativas de seus leitores.

De fato, se o leitor não recebe a obra de forma passível, mas interage com ela; se não é apenas um reprodutor, mas coautor, pois completa o sentido da obra a partir de seus horizontes de expectativas, depreende-se que, de alguma forma e em algum momento, ele deva expressar a sua recepção. Do contato do leitor com as obras ocorrem as interpretações e as considerações que vão se inserindo numa sociedade em determinado contexto. A obra de arte vai agregando valores conforme a recepção em cada sociedade. Ao longo do tempo, novas produções podem surgir a partir dessa leitura e recepção dos textos, inserindo-se ainda, nessas produções, as interpretações individuais dos produtores.

Ao incentivar a leitura e, partindo-se dela, a produção de conhecimentos por meio da elaboração de uma nova obra, oportuniza-se a expressão da recepção do texto. Essa expressão pode ser demonstrada de inúmeras formas: oralmente, em trabalhos escritos, em composições musicais, em imagens, enfim, conforme a opção e habilidade de cada indivíduo. A opção deste estudo pela produção visual do poema se deve à sua abordagem principal, que é a transposição de obras de linguagem escrita em obras de linguagem visual.

Nas últimas décadas arte e cultura deixaram os museus e ganharem as ruas, praças e ambientes públicos e particulares. Verdadeiras obras de arte são expostas em lugares onde antes não se imaginaria encontrá-las. Para um público que, no entanto, mostra-se cada vez mais insensível às manifestações artísticas e culturais, tem-se produzido obras interativas, interventivas, que buscam chamar a atenção desse público e induzi-lo à reflexão e interação. Apesar de todo esse empenho, no entanto, persiste um hiato entre público e obra. Isso pode estar relacionado ao fato de que, embora a arte contemporânea possua caráter interventivo e interativo, após sua recepção, há pouco ou nenhum espaço para manifestação do receptor. 
A reprodução técnica permite brotarem leituras e releituras de obras que podem ser consideradas manifestações da recepção, todavia, persiste a perda da aura. Historicamente, a união das narrativas, especialmente as mitológicas e bíblicas, às artes visuais, permitiu surgirem grandes obras, como a pintura do teto da Capela Sistina, feita por Michelangelo. Embora tenha sido um trabalho contratado para instruir visualmente um público, em sua maioria analfabeto, sobre a criação bíblica, o afresco de Michelangelo não perde seu status de obra de arte. Logo, a perda da aura não está na exploração de um tema repetido, ou na comercialização da obra, mas na reprodução técnica desprovida de inventividade.

No contexto atual, de muito acesso à leitura, porém de leitores superficiais e, muitas vezes, analfabetos visuais, o resgate das conexões produtivas entre artes visuais e literatura pode, a exemplo do que fizeram grandes artistas ao longo da História, valorizar a leitura de obras literárias e ainda motivar a produção de obras de arte contemporâneas, como a instalação artística. A imagem, quando não é produzida no intuito de dissimular uma totalidade que ela não possui, tende a instigar a curiosidade. Ela pode suscitar indagações e levar à busca por respostas mais complexas. Consequentemente, as conexões produtivas entre artes visuais e literatura podem fornecer-se, reciprocamente, inspiração, incentivo e difusão.

A contribuição dessa pesquisa no contexto educacional é a de estudar e resgatar conexões produtivas entre literatura e artes visuais, resultando na produção de obras de arte contemporânea que incentivam a leitura e divulgam a obra de arte visual e literária. Com embasamento na estética da recepção de Hans Robert Jauss e no sistema Image watching, de Robert William Ott, propõe-se uma metodologia de desencadeamento do processo criativo a partir da leitura de obras literárias, para produção de obra de arte híbrida da poesia e da arte visual.

A pesquisa teve início com a produção de uma instalação artística oriunda da leitura de um poema de Bertolt Brecht (1990). A princípio, um dos objetivos era mostrar aos estudantes o que era uma instalação artística e, principalmente, que eles próprios podiam elaborar instalações. Da constatação de que havia entre eles dificuldades em decidir sobre o tema de seus projetos e também em relação à leitura e interpretação de poemas, percebeu-se a viabilidade de união entre artes visuais e literatura para incentivar a produção e apreciação de ambas as práticas artísticas.

Então, no dia 23 de julho de 2012 esteve exposta no Centro de Ensino Fundamental 120 de Samambaia Sul a instalação artística Mensagem a um general, da professora e autora Kelly Vyanna. A instalação foi produzida a fim de se verificar, a partir de um caso concreto, o 
potencial educacional e artístico das conexões entre artes visuais e literatura, na produção de trabalhos artísticos e incentivo à leitura de poemas.

A instalação foi composta por peças esvoaçantes, feitas de tecido, brancas e pretas conforme um jogo de xadrez. Os formatos das peças correspondem ao jogo: reis, rainhas, bispos, cavalos, torres e peões, porém com rostos metálicos. Para elaboração desse rosto metálico, houve a colaboração de alguns estudantes que permitiram moldar com material alumínio o contorno de seus rostos. O chão logo abaixo das peças simboliza um tabuleiro e, ao centro, foi disposta uma balança. Do lado mais alto da balança, foi colocado um uniforme militar, do lado mais baixo, um peão ${ }^{15}$ bicolor: preto e branco. Havia ainda dois brinquedos sonoros representando as máquinas e os sons da guerra: um helicóptero e um tanque.

Apesar do ponto de partida da instalação ter sido a leitura do poema de Bertolt Brecht Palavras a um general, a obra não se propõe a repetir o poema, mas tão somente a simbolizar com imagens a sua mensagem. Ou seja, na elaboração da instalação artística Mensagem a um general, houve a interpretação do poema e uma tradução intersemiótica de seu conteúdo. Os signos não verbais utilizados para expressar os significados anteriormente dispostos em palavras, são de conhecimento geral, embora isso não garanta a sua assimilação. Como já foi observado no primeiro capítulo, as imagens, como símbolos, podem não ser interpretadas. Pode ocorrer que a imagem suscite apenas o que mostra a sua forma imediata, e não os significados simbólicos agregados a ela em determinadas culturas e contextos. Não obstante, justamente devido ao hiato frequente entre imagem e símbolo é que seu uso e pesquisa devem ser incentivados. Enfim, conforme consideração geral em relação ao jogo de xadrez como símbolo de raciocínio, pensamento lógico, é que ele foi escolhido para a composição da obra.

Devido à variação de interpretações que uma imagem e um símbolo suscitam, podendo servir ou não aos objetivos comunicativos de acordo com a sua assimilação ou ignorância em um contexto, o processo de recepção da obra original se torna imprescindível quando se pretende a elaboração de uma nova obra a partir dela. Quando a obra original é desconhecida da comunidade ou frustra o seu horizonte de expectativas, as associações de conteúdo se tornam mais distantes, e isso interfere na fruição estética da obra. De qualquer maneira, toda obra é passível de fruição estética, e o modo como isso ocorre depende de inúmeros fatores. O horizonte de expectativas, embora afete determinantemente a fruição de uma produção artística, também auxilia na sua interpretação. Como se pode perceber, ao longo do tempo é que se pode onalisar o processo de recepção da obra.

\footnotetext{
${ }^{15}$ O peão é a peça de menor valor no jogo de xadrez, entretanto, dependendo da situação do jogo, ela pode se transformar em peça mais valiosa e ser decisiva no resultado final.
} 
Figura 7 - fotografias da instalação Mensagem a um general captadas no momento da exposição.

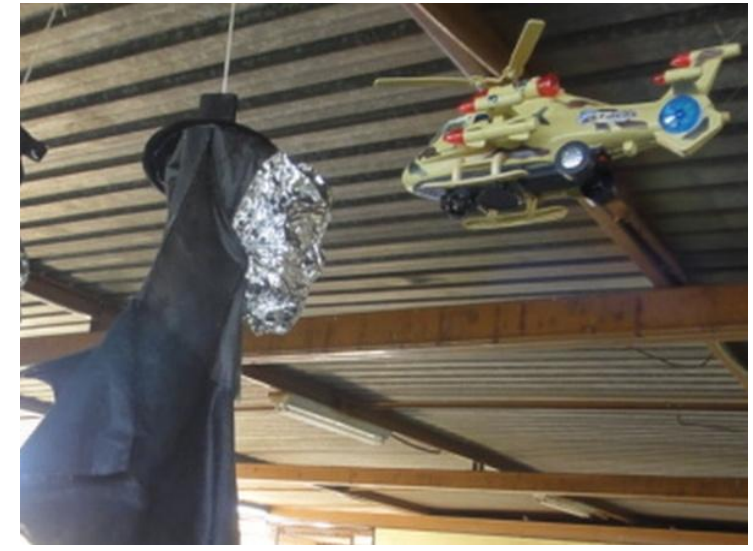

a)

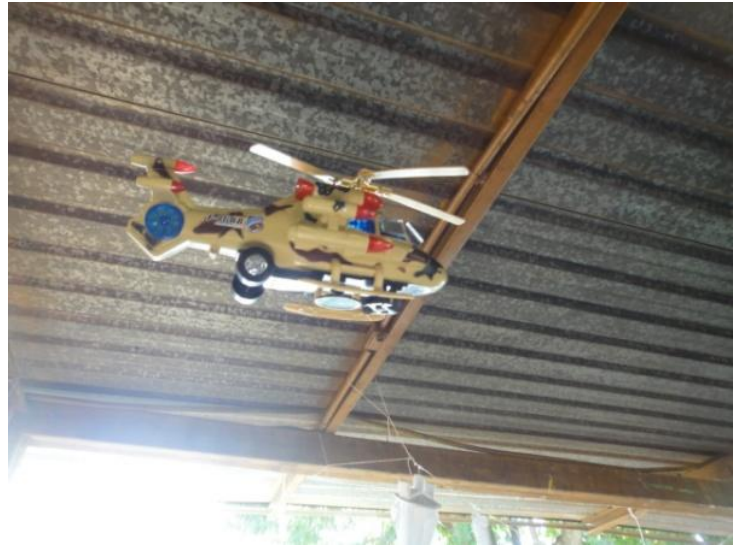

b)

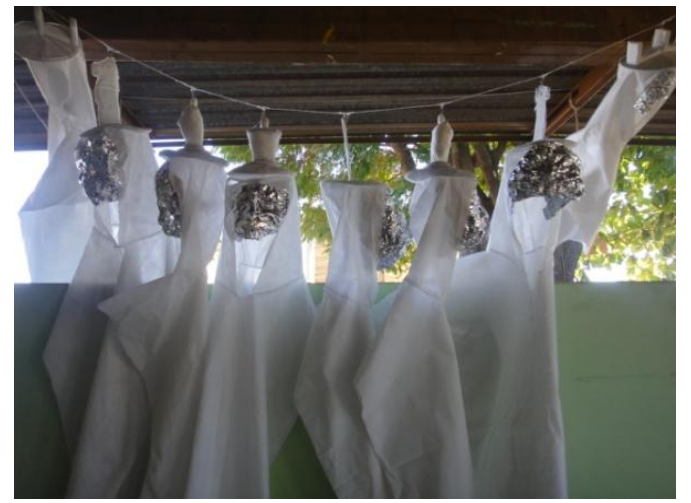

d)

c)

A fim de que haja o desencadeamento do processo de recepção de um texto (ou do conceito de uma obra de arte), é imprescindível que sua presença (real) seja inserida no corpo de uma comunidade de leitores e ouvintes. Essa presença real do texto pode ser identificada de diversas formas. É possível afirmar, inclusive, que a pintura mitológica, histórica e alegórica é uma forma de afirmação em potencial dessa presença. A recepção de narrativas mitológicas, na antiga Grécia, era tão natural quanto a recepção das obras de arte que se reportavam a elas. Afinal, a temática mitológica satisfazia ao horizonte de expectativas dos antigos gregos. Conforme Jauss, o processo de recepção do texto pretende,

[...] de um lado aclarar o processo atual em que se concretizam o efeito e o significado do texto para o leitor contemporâneo e, de outro, reconstruir o processo histórico pelo qual o texto é sempre recebido e interpretado diferentemente, por leitores em tempos diversos. A aplicação, portanto, deve ter por finalidade comparar 
o efeito atual de uma obra de arte com o desenvolvimento histórico de sua experiência e formar o juízo estético, com base nas duas instâncias de efeito e recepção. (idem, 2002a, p. 70).

As obras de temática mitológica assumem, nos dias atuais e em todo o mundo, efeito e significado diversos dos que possuíam na antiga Grécia. Sua recepção hoje depende do contexto e do horizonte de expectativas do observador, que é muito diferente dos horizontes dos antigos gregos. Quanto à arte híbrida Mensagem a um general, exposta na escola de Samambaia-Sul, pressupõe uma ruptura dos horizontes de expectativas, uma vez que a obra literária de Brecht, da qual nasceu a instalação artística mencionada, não faz parte do sistema de referências daquela comunidade. Resta o confronto com as experiências individuais de cada receptor.

A estética da recepção apontou para um leitor que não apenas decodifica signos de um sistema de linguagem, mas, sobretudo, constrói significados. De fato,

pode-se na história de um texto poético, distinguir vários momentos: o momento de sua formação, depois, necessariamente (uma vez que esse texto, pelo menos de maneira virtual, destina-se a se tornar público), há a transmissão. Esta propicia a Recepção. Depois ele se conserva, em consequência da outra característica própria do texto poético, desalienar-se no que se refere às limitações do tempo. Em seguida teremos outras recepções em número indefinido. Eu as reúno sob o nome de reiteração Em cada um desses momentos o suporte pode ser tanto a palavra viva quanto a escrita. Disso resulta teoricamente (salvo erro) centenas de situações possíveis! (ZUMTHOR, 2007, p. 65).

Aqui, além dos suportes propostos por Zumthor da palavra viva ou escrita, acrescentase o suporte visual da instalação artística. Partindo-se do princípio de que uma das características do texto poético é desalienar-se às limitações do tempo, não foi considerada a contextualização histórica de produção do poema. Isso não significa que a contextualização não seja importante para um trabalho interpretativo, entretanto, o objetivo aqui é justamente o de observar como a mensagem do texto se atualiza no tempo e na linguagem, independentemente do contexto no qual foi produzida.

Não obstante, o contexto em que viveu o autor e no qual ocorreu a produção da obra de referência devem ser considerados, a título de conhecimento. O poeta e dramaturgo Bertolt Brecht, nasceu na Alemanha em 1898, e viveu a experiência das duas grandes guerras. Na segunda grande guerra, exilou-se em vários países. Propôs uma mudança de perspectiva em relação ao teatro, direcionando-o como elemento libertador e conscientizador do homem, em vez de apenas promotor de catarse. Elaborou, então, a proposta de teatro épico, que visa envolver o público nas questões levantadas numa encenação dramática. 
Quando se assiste a uma peça teatral, um filme, uma novela, a tendência é haver uma identificação com algum personagem, o herói, o protagonista. Esse personagem interfere na ótica do sujeito que se identifica com ele, influenciando suas opiniões, sentimentos e o modo como ele percebe o mundo. Esse processo de identificação vem sendo analisado desde Aristóteles, mas Brecht decidiu romper com ele e, baseando-se em princípios marxistas, infundiu em seu teatro épico a ideia do indivíduo como parte de uma sociedade que determina suas formas de pensar e agir.

O objetivo do teatro épico era, em linhas gerais, tornar as pessoas mais críticas em relação à realidade, motivando nelas o desejo por mudanças e o entendimento de que as atitudes individuais e coletivas podem propiciar as transformações necessárias para uma sociedade mais justa. No lugar da identificação com os personagens e situações representadas, Brecht propõe o distanciamento e a crítica. Dessa forma, acreditava que o teatro poderia ser mais útil, não apenas divertido, e serviria de auxílio na luta contra a opressão política e social, contra as guerras, as ditaduras e as injustiças sociais.

O poema Palavras a um general revela um pouco do pensamento de Brecht, pois expõe de maneira bastante clara a força do homem comum em contraposição à vontade dos detentores do poder, representados na figura do general. O poema foi escolhido para a realização da instalação artística justamente por propiciar uma reflexão crítica em relação ao modo de pensar, sentir e agir de cada indivíduo e como isso determina a mudança de condição de vida de uma coletividade. A metodologia usada para desempenho do processo criativo de produção da instalação também se relaciona à postura crítica frente a uma obra de arte.

O processo criativo pode ser desencadeado de inúmeras formas, mas a curiosidade e a compreensão de um determinado tema auxiliam e irrompem os seus mecanismos. A leitura e recepção de um poema é, frequentemente, fonte de inspiração para outras criações. De acordo com Fayga Ostrower (1987, p.9): "o ato criador abrange, portanto, a capacidade de compreender, e, esta, por sua vez, a de relacionar, ordenar, configurar, significar". A primeira etapa para a elaboração da instalação artística Mensagem a um general foi a leitura e compreensão do texto de referência Palavras a um general.

O modo de leitura é aquele que Machado de Assis, em seu livro Esaú e Jacó (2008) chamou de leitura ruminante, ou seja, aquela em que o leitor entra em contato com o texto num primeiro momento, depois exerce a reflexão a seu respeito, faz nova leitura, nova reflexão e, somente então é capaz de se pronunciar sobre a leitura. Quando da compreensão e interpretação pessoal do texto, revela-se a sua recepção individual e coletiva. As leituras e reflexões sobre o poema podem ser consideradas uma etapa de aquecimento que 
correspondem a uma sensibilização à prática artística. Essa etapa é conhecida como Thought watching. As etapas seguintes são de relacionamento, ordenamento, configuração, significação do poema em nova obra de arte híbrida da poesia e da instalação.

$\mathrm{Na}$ produção da instalação artística, a metodologia usada foi a do sistema Image watching, que sugere as seguintes etapas de análise crítica de uma obra de arte: descrevendo, analisando, interpretando, fundamentando, revelando (surgimento da nova obra de arte). Esse sistema, criado pelo professor e pesquisador Robert William Ott, da Pen State University (Universidade Estadual da Pensilvânia), Estados Unidos, foi difundido originalmente para o ensino de crítica de arte em museus. Pode, no entanto, ser aplicado também como metodologia de apreciação e produção de arte em geral, pois, conforme o próprio autor sugere: "Ensinar crítica, usando uma abordagem visual ou verbal como técnica de aprendizagem, exige um sistema que efetivamente promova realização aos alunos." (OTT, 1997, p. 137).

Dessa forma, após a leitura e as reflexões a respeito do poema de Brecht, a próxima etapa, que corresponde à primeira do sistema Image watching (descrevendo), foi a de descrever as imagens que o poema suscita na mente do leitor. Cada leitor pode ter uma experiência diferente, mas algumas imagens serão identificadas por uma grande maioria de leitores. Da leitura desse poema, as imagens evocadas foram: uma patente militar, uniformes, tanque de guerra, carro forte, floresta, árvores caindo, homens morrendo, helicóptero, aviões, cenas de guerra. Além disso, foi destacada do poema uma palavra-chave: "pensar". A palavrachave é de livre escolha do leitor, sua função é descrever o elemento principal que orienta todo o texto.

A categoria analisando foi feita, de acordo com os critérios do sistema Image watching, partindo-se para o reconhecimento dos elementos estéticos que constituem a obra. Nessa etapa a obra é analisada em seus elementos intrínsecos e o enfoque se detém na organização e disposição dos elementos no texto. No caso do poema, são analisadas as composições de versos e estrofes, a utilização de palavras e metáforas, a contagem de sílabas, a definição do ritmo, a construção ou ausência de rimas.

A interpretação do texto (categoria interpretando) é auxiliada pelas etapas anteriores e, a partir delas, a ótica pessoal e crítica é revelada. Nesse momento, pode-se identificar como o horizonte de expectativas dos leitores influencia a interpretação da obra. Então, partindo-se para a categoria fundamentando, a interpretação pessoal é confrontada com estudos, textos acadêmicos e teorias de embasamento para as questões suscitadas durante a interpretação do poema. 
Enfim, na categoria revelando, a leitura e compreensão do poema se torna a fonte propulsora da produção de uma nova obra de arte. Oportuniza-se, assim, a transposição da obra de linguagem verbal (o poema Palavras a um general) em obra de linguagem não verbal (a instalação artística Mensagem a um general). O próprio título já destaca a ocorrência da transposição.

Entre os elementos da instalação foram selecionados alguns brinquedos sonoros. Da categoria descrevendo obteve-se imagens mentais e imagens concretas. Os brinquedos remetem às imagens concretas que o poema propõe. As imagens concretas podem ser reveladas com o auxílio de objetos, ou seja, os brinquedos. São eles: tanque e helicóptero militar com espelhos no lugar dos motoristas. Assim, cada observador pode ter a experiência de enxergar a si próprio como o motorista e o mecânico do poema de Brecht. Da palavrachave (pensar) surgiu a ideia do jogo de xadrez. O chão foi coberto por um tapete de tecido xadrez preto e branco, tendo, no centro, uma balança com um peão em preto e branco do lado mais baixo, e um uniforme militar do lado mais alto, para demonstrar a hierarquia. Fantasias representativas das peças de xadrez, em tecido preto e branco foram penduradas e ficaram a esvoaçarem-se. Há, então, o simbolismo do jogo de xadrez que sugere uma organização militar ou social.

Essa instalação, sendo exposta de forma efêmera e interventiva na escola, tem como desdobramento suscitar uma atmosfera propícia à criação de novas obras a partir da sua recepção pelos alunos, professores e demais indivíduos da comunidade escolar. Para tanto, este trabalho pressupõe, na sequência, a coleta de dados referente à recepção da instalação, por meio de um questionário. Seguem as questões formuladas pela autora, a fim de se averiguar como ocorreu a recepção do trabalho artístico, e a assimilação da proposta de hibridismo entre artes visuais e literatura.

Questionário sobre a instalação artística Mensagem a um general:

1. Qual foi a sua reação ao se deparar com a obra ao chegar à escola?

2. Você conhece a arte da instalação?

3. Levando-se em consideração a obra que você viu, qual a sua opinião a respeto desse tipo de arte?

4. O que mais chamou a sua atenção na obra, por quê?

5. Há símbolos que você não conhece inseridos na obra? Quais?

6. Por que, em sua opinião, a obra se chama Mensagem a um general? 
7. Você conhecia o poema Palavras a um General?

8. Comente suas impressões pessoais a respeito do poema

9. Comente suas impressões pessoais a respeito da instalação

10. Se você tivesse de usar esse mesmo poema como tema para uma nova criação artística ou científica numa feira de artes e ciências, o que você gostaria de apresentar?

Alunos, professores e demais componentes da comunidade escolar foram convidados à apreciação da obra e a responderem a este questionário. Cada um que esteve presente à realização desse projeto de instalação artística teve liberdade de escolha em responder ou não cada pergunta. As respostas, igualmente, foram dadas a partir da livre opinião de cada participante. Algumas turmas de estudantes que participaram da montagem e apreciação da obra também compuseram uma roda de conversas a respeito dos assuntos oriundos da realização do projeto.

As respostas ao questionário demonstraram que a maioria dos estudantes desconhecia a arte da instalação artística. Alguns nunca haviam percebido as interferências urbanas das artes contemporâneas como manifestação artística. Também foi observado desconhecimento dos estudantes em relação ao poema e ao autor escolhidos. A exposição da instalação gerou bastante interesse e curiosidade dos estudantes e de toda comunidade escolar. As turmas que fizeram uma roda de conversa sobre a instalação e o poema participaram ativamente e com entusiasmo. Houve sugestões, comentários, críticas e considerações gerais em relação ao tema dos trabalhos artísticos. Alguns manifestaram interesse em produzir um trabalho semelhante.

Conclui-se que a leitura do texto literário suscita questionamentos nas mais diferentes esferas do relacionamento humano, mas percebe-se um hiato quando do compartilhamento desses questionamentos. A expressão oral e escrita sobre essas emanações da arte e da literatura são imprescindíveis, no entanto, limitam as formas de expressão, deixando de contemplar, cientificamente, áreas de conhecimento e comunicação humanas não verbais. A proposta é de que essa metodologia de leitura do texto, recepção e produção visual, possa contribuir para o engajamento de obras literárias nos processos criativos e investigativos elaborados nas escolas e nas feiras de arte e ciência. Portanto, propõe-se ampliar as análises de arte e literatura para além de seus atributos verbais, levando-se em consideração as fortes impressões visuais que elas evocam.

Enfim, a metodologia usada na produção da obra Mensagem a um general, com embasamento teórico na estética da recepção e no sistema de crítica Image watching, poderá servir de guia para a execução de projetos semelhantes que busquem em arte e literatura uma 
forma de expressão de conhecimentos. A elaboração e compartilhamento de conhecimentos gerais e científicos em feiras educacionais podem formar vínculos com artes e literatura, uma vez que são áreas do conhecimento que tratam de todos os assuntos que inquietam a humanidade. Na combinação das linguagens visuais e verbais, amplia-se o potencial de exploração dos conhecimentos humanos, na medida em que sejam realizadas as análises críticas concernentes aos elementos comunicativos de cada uma destas linguagens. 


\section{CONCLUSÃO}

Literatura e outras artes estabelecem entre si diversos tipos de associações sendo que, em alguns casos, há a união de duas ou mais linguagens diferentes em diálogo numa mesma obra e, em outros, há tradução intersemiótica de uma obra original. A tradução intersemiótica ocorre quando o conteúdo e a elaboração de uma obra anterior são intencionalmente transpostos a outra linguagem, promovendo a transferência adaptada de um signo a outro. As obras que foram analisadas nesta pesquisa podem ser consideradas uma tradução intersemiótica do conto A terceira margem do rio, de João Guimarães Rosa.

O conto, originalmente escrito em prosa, foi adaptado para a linguagem musical na canção de Caetano Veloso e Milton Nascimento. Primeiro Milton Nascimento compôs a melodia inspirado nas ideias contidas no conto. Depois, Caetano compôs a letra poética. A canção foi, então, transposta à linguagem visual na instalação artística de Guto Lacaz. Esta pesquisa empreendeu uma análise de como ocorrem essas transposições, observando que cada linguagem artística comunica a ideia primeira do conto por meio de seus recursos e elementos estéticos específicos.

Dessa forma, na transposição do conto à canção, há tratamento mais subjetivo das ideias e ampliam-se as associações simbólicas, uma vez que é próprio da linguagem poética o uso de símbolos. Foi verificado que, por meio dos sons, a melodia estabeleceu comunicação adequada dos elementos oriundos do conto, como a evocação do ambiente beira-rio e sugestão sonora propícia à sensação de enigma e incertezas decorrentes do acontecimento extraordinário descrito no conto. A imagem estática, por sua vez, tende a sintetizar o discurso, selecionando fragmentos impactantes ao comunicar mensagens. Guto Lacaz, com a representação de três canoas, sendo uma delas apenas imagem do inverso da outra, refletida num espelho, conseguiu fazer o observador enxergar uma terceira margem entre as duas canoas concretas. Utilizando-se dos recursos próprios de sua arte, cada autor alcançou o objetivo de comunicar a existência de uma terceira margem do rio.

Ao longo desse trabalho foi constatado que, por meio da literatura e de outras artes, o ser humano propõe o conhecimento e a assimilação de si mesmo e dos outros. A história de cada pessoa se compõe de narrativas que vão sendo formuladas ao longo do tempo, quer seja por si mesmo, ou pelos outros. Consequentemente, a narrativa de si, em conjunto com as narrativas de outros, determinam a identidade do sujeito. $\mathrm{O}$ sujeito pode ser aquele que se fixou na primeira margem (alegoria proposta por esta pesquisa no que se refere ao posicionamento do sujeito em relação aos outros) e que daí determina todas as coisas a partir 
de uma perspectiva centrada no Eu. Também pode ser aquele que intenta uma autoafirmação, impondo-se contra a mesmidade dos sujeitos da primeira margem e, posicionando-se, então, na segunda. Ou, pode ser ainda, aquele que empreendeu uma ruptura consigo mesmo, proporcionando, assim, abertura a uma terceira margem, lugar neutro onde é possível a coexistência do Eu e do Outro numa relação não de totalidade, mas de infinito. Esse relacionamento infinito com o Outro é o maior empreendimento ao qual se lançam autores e artistas.

Contudo, muitos acabam naufragando ao tentar atravessar o rio rumo à alteridade. Sendo assim, esta pesquisa tratou de demonstrar como alguns tipos de discursos deturpam ou negligenciam o Outro. Mitos e estereótipos também são construídos por meio da literatura e de outras artes. Embora a mímesis seja uma manifestação comum a todas as pessoas, a partir do momento em que uma representação passa a ser difundida, torna-se sujeita aos desdobramentos dos discursos que nela ou sobre ela são inseridos. As imagens, mais do que o texto verbal, tende a naturalizar e difundir discursos preconcebidos. Por sua fixidez e capacidade de síntese, pode formular estereótipos e conduzir a criação de mitos. Como forma de comunicação imediata, pode desempenhar com maior rapidez o acesso e divulgação de ideias falsas ou preconceituosas.

Por tudo isso, a fim de promover mais estudo e informação acerca dessas duas linguagens artísticas, devem ser incentivadas as conexões produtivas entre artes visuais e literatura. A tradução intersemiótica de textos literários tende a conduzir o leitor do texto à leitura das imagens. Se a recíproca ainda não é verdadeira se deve ao fato de que muitas pessoas demonstram certa preferência pela informação visual, em detrimento do texto. Porém, o uso de imagens tem se demonstrado como ação relevante no sentido de fomentar a leitura.

A predominância da informação visual acontece em muitas culturas e nos mais diversos contextos, devido, entre outros motivos, à capacidade de síntese e imediatismo na comunicação que as imagens proporcionam. O desenvolvimento tecnológico não é o único responsável pela acomodação dos leitores às narrativas visuais, mas é, com certeza, facilitador da produção e reprodução excessiva de imagens, assim como propagador intensivo das mesmas. Como se pode verificar, faz-se cada vez mais necessário e urgente o estudo e a aplicação das imagens (de maneira crítica), bem como o desenvolvimento da compreensão de seus limites, potencialidades e expressões adequadas.

A forma como o excesso de informação visual é recebido e a análise crítica formulada em torno das imagens deve ser pensada a fim de se evitar erros, omissões e falsos julgamentos. Sobretudo, levando-se em consideração o poder de impacto que as imagens 
tendem a exercer na memória, a inserção da análise crítica das imagens dentro e fora de seu contexto e a construção de uma narrativa escrita mais abrangente sobre o que elas mostram, podem auxiliar a compreensão das questões por elas propostas.

Embora a informação visual possua maior capacidade de alcance espacial, intelectual e temporal, no sentido de que chega mais facilmente e rapidamente a lugares distantes, de difícil acesso, e também consegue alcançar letrados e iletrados, ela esbarra em suas limitações comunicativas. Entretanto, apesar de sua superficialidade, a informação visual se impõe com muito mais força imediata do que a informação escrita e, por isso mesmo, deve ser vista não como um todo autoritário e autônomo, mas como parte de um contexto mais abrangente do qual ela é parte.

No contexto educacional, imagens são frequentemente usadas com o intuito de facilitar a assimilação de conteúdos, no entanto, o estudo da análise das imagens ainda é escasso. Em se considerando que, com o desenvolvimento tecnológico, o uso, a reprodução e a manipulação de imagens tornaram-se mais acessíveis, estudos e questionamentos a este respeito devem ser cada vez mais estimulados. O exame das imagens, bem como a análise do uso que se faz delas, tem se tornado imprescindível a fim de se compreender mais profundamente o discurso, a estética e a ideologia que elas podem sugerir isoladamente ou em conjunto com o texto verbal.

O processo de leitura, recepção e transposição de linguagens foi bastante empregado por artistas em representações da mitologia, de histórias bíblicas, de fatos históricos e em alegorias. Nesse contexto, o processo criativo é desencadeado a partir de uma narrativa conhecida (linguagem verbal oral ou escrita), que se converte em linguagem artística visual (pintura, escultura, instalação). Esse processo tende a enriquecer a discussão em torno das potencialidades estéticas e comunicativas de cada linguagem.

A obra de arte produzida a partir da recepção do poema é transdisciplinar e interventiva: sua produção e exposição no ambiente escolar proporcionou aos estudantes e a todos os presentes, contato e interação com a arte contemporânea, além de fomentar o debate em relação à poesia. Numa atividade como essa, imagem e texto se unem em ambiente adequado para as indagações que devem ser feitas sobre essa relação. Porém, atenção maior deve ser dada à conscientização das pessoas em relação ao processo comunicativo de imagens e textos, isoladamente e combinados.

A produção de uma instalação artística construída a partir da recepção da poesia de Brecht é, portanto, um modo de resgatar as conexões entre obra literária e obra visual, promovendo o hibridismo. Além disso, proporcionou o estudo e debate em relação aos efeitos 
comunicativos do texto e da imagem. A opção pela instalação se deve ao fato de ser esta uma arte visual efêmera e, assim, melhor se ajustar aos pressupostos da estética da recepção no que concerne ao horizonte de expectativas, sujeito a alterações e mudanças conforme as experiências vividas pelo leitor. Para suprir a necessidade de uma metodologia crítica e efetiva que desencadeasse nos estudantes o processo criativo, foi escolhido o sistema Image watching, de Robert William Ott.

A produção híbrida instigou interesse e investigações a respeito da instalação artística e do poema. Fomentou o estudo dos elementos visuais na comunicação de mensagens em confronto com a linguagem verbal. Também promoveu a difusão de um método para produção de trabalhos artísticos a partir da combinação entre artes visuais e literatura.

Esta pesquisa desenvolveu com propriedade uma análise interates do conto A terceira margem do rio, de João Guimarães Rosa; demonstrou que a tradução intersemiótica é uma atividade enriquecedora no que diz respeito à produção de obras de arte e para os processos de criatividade; relacionou texto, música e imagem aos seus devidos processos de manifestação de expressão humana, cada um por seus atributos únicos e imprescindíveis; formulou considerações sobre a alteridade nos processos de leitura e escrita e apresentou proposta de atividade interartes executada numa escola pública de Samambaia-DF, com o objetivo de promover a leitura, produção, análise e divulgação de obras de arte e da literatura. 


\section{REFERÊNCIAS}

ACHER, Michael. Arte Contemporânea: uma história concisa. São Paulo: Martins Fontes, 2001.

ARISTÓTELES. Poéticas. Trad., pref., introd., com., apend. de Eudoro de Sousa. Porto Alegre: Globo, 1966.

ASSIS, Machado de. Esaú e Jacó. Porto Alegre: L\&PM, 2008.

AMBEVBRASIL. 22/05/2010. A terceira margem do rio - Guto Lacaz. Disponível em: https://www.flickr.com/photos/ambev/sets/72157623546601503/detail/ acesso em 25 de outubro de 2014.

AUMONT, Jacques. A imagem. Papirus: São Paulo, 2004.

BAKHTIN, Mikhail. Estética da criação verbal. Tradução de Maria Ermantina Galvão G. Pereira. Martins Fontes: São Paulo, 1997.

BARTHES, Roland. Mitologias. Rio de Janeiro: Difel, 2009.

BAUDELAIRE, Charles. Escritos sobre arte. Org. e trad. Plínio Augusto Coêlho. São Paulo: Hedra, 2008.

BAUMAN, Zygmunt. O mal-estar da pós-modernidade. Rio de Janeiro: Jorge Zahar Editor, 1998.

BENJAMIM, Walter. A obra de arte no tempo da sua reprodutibilidade técnica. In: ADORNO, Theodor W. et. al. Teoria da cultura de massa. Tradução de Carlos Nelson Coutinho. São Paulo: Paz e Terra, 2000, p. 221-254.

BETTON, Gérard. Estética do cinema. Tradução de Marina Sppenzeller. São Paulo: Martins Fontes, 1987.

BLANCHOT, Maurice. O espaço literário. Tradução de Álvaro Cabral. Rio de Janeiro: Rocco, 2011.

O livro por vir. Tradução de Leyla Perrone-Moisés. São Paulo: Martins Fontes, 2005.

BORGES, Jorge Luís. O Aleph. São Paulo: Globo, 1998

BOSI, Alfredo. O ser e o tempo da poesia. São Paulo: Cultrix, 1977.

BOURDIEU, Pierre. As regras da arte: gênese e estrutura do campo literário. Tradução de Maria Lúcia Machado. São Paulo: Companhia das letras, 1996.

BRECHT, Bertolt. Poemas de Svendborg. In: Poemas: 1913-1956. São Paulo: Brasiliense, 1990. 
BULFINCH, Thomas. O livro de ouro da mitologia: histórias de deuses e heróis. Tradução de David Jardim Júnior. Rio de Janeiro: Ediouro, 2006.

BURKE, Peter. Testemunha ocular - História e imagem. Edusc: São Paulo, 2004.

CARAMELLA, Elaine. História da arte: fundamentos semióticos: teoria e método em debate. Edusc, 1998.

CYNTRÃO, Sylvia Helena. Como ler o texto poético: caminhos contemporâneos. Brasília: Plano, 2004.

COMPAGNON, Antoine. O demônio da teoria: literatura e senso comum. Tradução de Cleonice Paes Barreto Mourão. Belo Horizonte: UFMG, 1999.

COSTA, Isaías. 07 de fevereiro de 2014. A escultura chamada ser humano. Disponível em: http://paralemdoagora.wordpress.com/2014/02/07/a-escultura-chamada-ser-humano/ Acesso em 24 de outubro de 2014.

DERRIDA. Jacques. O animal que logo sou (a seguir). Tradução de Fábio Landa. São Paulo: Unesp, 2002.

DONIS, A. Donis. Sintaxe da Linguagem Visual. São Paulo: Martins Fontes, 1997.

DUÍLIO, Battistoni Filho. Pequena história da arte. Campinas: Papirus, 1998.

ECO, Humberto. Intepretação e superinterpretação. São Paulo: Martins Fontes, 2005. Os limites da interpretação.São Paulo: Perspectiva, 2004.

ELIADE, Mircea. Imagens e Símbolos. Portugal: Editora Arcádia, S.A.R.L, 1979.

FOUCAULT, Michel. A ordem do discurso. Tradução de Laura Fraga de Almeida Sampaio. São Paulo: Loyola, 2007. As palavras e as coisas. Tradução de Salma Tannus Muchail. São Paulo: Martins Fontes, 2000.

Isto não é um Cachimbo. Tradução de Jorge Coli. São Paulo: Paz e Terra, 2008.

FRAGA, Plínio. 29/08/2014. Marina rema em direção à terceira margem do rio para contornar conflito situação/oposição. Disponível em: http://br. notícias. yahoo. com /blogs/plinio-fraga/marina-rema-em-direção-à-terceira-margem-do-rio-para-contornarconflito-situação-oposição-192728921.html acesso em 04 de setembro de 2014.

GIRARD, René. A violência e o Sagrado. São Paulo: Paz e Terra, 1998.

HUTCHEON, Linda. Poética do pós-modernismo: história, teoria, ficção. Tradução de Ricardo Cruz. Rio de Janeiro: Imago, 1991.

JAUSS, Hans Robert. A Estética da recepção: colocações gerais. In: LIMA, Luiz Costa (Coord. e Trad.). A literatura e o leitor: Textos de estética da recepção. Rio de Janeiro: Paz e Terra, 2002 a. p. 67-84. 
A história da literatura como provocação à teoria literária. Tradução de Sérgio Tellaroli. São Paulo, Ática, 1994.

JOLY, Martine. Introdução à análise da imagem. Lisboa: Editora 70, 2007.

JONIOJ. 31/01/2011. Milton Nascimento (Caetano Veloso) Terceira Margem do Rio.mp4. Disponível em: https://www.youtube.com/watch?v=j32B7tz-5Cs acesso em 25 de outubro de 2014.

JUNG, Carl G. O homem e seus símbolos. Rio de Janeiro: Nova fronteira, 1964.

LACAN, Jacques. O seminário, livro II, Os quatro conceitos fundamentais da psicanálise. Rio de Janeiro: Jorge Zahar, 1998.

LESSING, Gotthold Ephraim. Laocoonte. México: Nuestros clássicos, 1960.

LÉVINAS, Emmanuel. Entre nós - Ensaios sobre alteridade. Rio de Janeiro, Vozes, 2004. Totalidade e infinito. Trad. José Pinto Ribeiro. Lisboa, Edições 70, 1980.

LORENZ, Günter. Diálogo com Guimarães Rosa. In: Guimarães Rosa. COUTINHO, Eduardo (org.). Rio de Janeiro: Civilização Brasileira, 1983, p. 62-97.

LIMA, Luiz Costa. Mímesis: desafio ao pensamento. Rio de Janeiro: Civilização Brasileira, 2000 .

OSTROWER, Fayga. Criatividade e processos de criação. Rio de Janeiro: Vozes, 1987.

OTT, Robert William. Ensinando crítica nos museus. In: BARBOSA, Ana Mae (org.) Arteeducação: leitura no subsolo. São Paulo: Cortez, 1997.

PETIT, Michèle. A arte de ler ou como resistir à adversidade. Traduçao de Arthur Bueno e Camila Boldrini. São Paulo: Editora 34, 2009.

PlATÃO. A República. Tradução de de M. H. R. Pereira. Lisboa: Fundação Calouste Gulbenkian, 1989.

PLAZA, Julio. Tradução intersemiótica. São Paulo: Perspectiva, 2003.

PRAZ, Mário. Minemosyne: el paralelismo entre la literatura y las Artes Visuales. Madri: Taurus, 1979.

PROENÇA, Graça. História da arte. São Paulo: Ática, 2004.

RICOEUR, Paul. A metáfora viva. São Paulo: Edições Loyola, 2000. O si mesmo como um outro. Campinas: Papirus, 1991. .Tempo e narrativa - Tomo I. Tradução de Constança Marcondes Cesar. Campinas: Papirus, 1985.

RIBEIRO, Solange. Literatura e as outras artes hoje: o texto traduzido. Revista Letras $\mathrm{n}^{\mathrm{o}} 34$. Literatura, outras artes e cultura das mídias. Santa Maria, 10 de janeiro de 2007. ROSA, João Guimarães. Primeiras estórias. Rio de Janeiro: Nova Fronteira, 2001. 
SGANZERLA, Rogério. Por um cinema sem limite. Rio de Janeiro: Azougue, 2001.

SOURIAU, Éttiene. A correspondência das artes: elementos de estética comparada. São Paulo: Cultrix, 1983.

STAUROMEL-alquimiaDigital. 23 de setembro de 2010. Laocoonte y sus hijos- Museos Vaticanos. Disponível em: https://www.flickr.com/photos/stauromel/5128244016/ Acesso em 24 de outubro de 2014.

SANTANA, Romano Affonso de. Paródia, paráfrase \& Cia. São Paulo: Ática, 2003.

SPERBER, Suzi Frankl. Presença do sagrado na literatura. Questões teóricas e de hermenêutica. São Paulo: Publiel-Unicamp, 2011.

STEINER, George. O leitor incomum. In: Nenhuma paixão desperdiçada. Rio de Janeiro: Record, 2001, p. 13-31.

STRICKLAND, Carol. Arte comentada. Da pré-história ao pós-modernismo. Tradução de Angela Lobo de Andrade. Rio de Janeiro: Ediouro, 2004.

TABORDA, Felipe (org.). A imagem do som de Caetano Veloso: 80 composições de Caetano Veloso interpretadas por 80 artistas contemporâneos Vol. I. Rio de Janeiro: Francisco Alves, 1998.

TATIT, Luiz. O cancionista: composição de canções no Brasil. São Paulo: Edusp, 1996. Semiótica à luz de Guimarães Rosa. São Paulo: Ateliê Editorial, 2010.

TODOROV, Tzvetan. A literatura em perigo. Tradução de Caio Meira. Rio de Janeiro: Difel, 2009.

TIRAPELI, Percival. Arte brasileira. Arte moderna e contemporânea. Figuração, abstração e novos meios. São Paulo: Companhia Editora Nacional, 2006.

VYANNA, Kelly. Mensagem a um general. 23 de julho de 2012. 4 fotografias, color.

ZUMTHOR, Paul. Performance, recepção, leitura. Tradução de Jerusa Pires Ferreira e Suely Fenerich. São Paulo: Ed. Cosac Naify, 2007. 


\section{ANEXO}

\section{I - A terceira margem do rio}

(conto de João Guimarães Rosa)

Nosso pai era homem cumpridor, ordeiro, positivo; e sido assim desde mocinho e menino, pelo que testemunharam as diversas sensatas pessoas, quando indaguei a informação. Do que eu mesmo me alembro, ele não figurava mais estúrdio nem mais triste do que os outros, conhecidos nossos. Só quieto. Nossa mãe era quem regia, e que ralhava no diário com a gente - minha irmã, meu irmão e eu. Mas se deu que, certo dia, nosso pai mandou fazer para si uma canoa.

Era a sério. Encomendou a canoa especial, de pau de vinhático, pequena, mal com a tabuinha da popa, como para caber justo o remador. Mas teve de ser toda fabricada, escolhida forte e arqueada em rijo, própria para dever durar na água por uns vinte ou trinta anos. Nossa mãe jurou muito contra a ideia. Seria que, ele, que nessas artes não vadiava, se ia propor agora para pescarias e caçadas? Nosso pai nada não dizia. Nossa casa, no tempo, ainda era mais próxima do rio, obra de nem quarto de légua: o rio por aí se estendendo grande, fundo, calado que sempre. Largo, de não se poder ver a forma da outra beira. E esquecer não posso, do dia em que a canoa ficou pronta.

Sem alegria nem cuidado, nosso pai encalcou o chapéu e decidiu um adeus para a gente. Nem falou outras palavras, não pegou matula e trouxa, não fez a alguma recomendação. Nossa mãe, a gente achou que ela ia esbravejar, mas persistiu somente alva de pálida, mascou o beiço e bramou: — "Cê vai, ocê fique, você nunca volte!" Nosso pai suspendeu a resposta. Espiou manso para mim, me acenando de vir também, por uns passos. Temi a ira de nossa mãe, mas obedeci, de vez de jeito. $\mathrm{O}$ rumo daquilo me animava, chega que um propósito perguntei: — "Pai, o senhor me leva junto, nessa sua canoa?" Ele só retornou o olhar em mim, e me botou a bênção, com gesto me mandando para trás. Fiz que vim, mas ainda virei, na grota do mato, para saber. Nosso pai entrou na canoa e desamarrou, pelo remar. E a canoa saiu se indo - a sombra dela por igual, feito um jacaré, comprida longa.

Nosso pai não voltou. Ele não tinha ido a nenhuma parte. Só executava a invenção de se permanecer naqueles espaços do rio, de meio a meio, sempre dentro da canoa, para dela não saltar, nunca mais. A estranheza dessa verdade deu para. estarrecer de todo a gente. 
Aquilo que não havia, acontecia. Os parentes, vizinhos e conhecidos nossos, se reuniram, tomaram juntamente conselho.

Nossa mãe, vergonhosa, se portou com muita cordura; por isso, todos pensaram de nosso pai a razão em que não queriam falar: doideira. Só uns achavam o entanto de poder também ser pagamento de promessa; ou que, nosso pai, quem sabe, por escrúpulo de estar com alguma feia doença, que seja, a lepra, se desertava para outra sina de existir, perto e longe de sua família dele. As vozes das notícias se dando pelas certas pessoas — passadores, moradores das beiras, até do afastado da outra banda - descrevendo que nosso pai nunca se surgia a tomar terra, em ponto nem canto, de dia nem de noite, da forma como cursava no rio, solto solitariamente. Então, pois, nossa mãe e os aparentados nossos, assentaram: que o mantimento que tivesse, ocultado na canoa, se gastava; e, ele, ou desembarcava e viajava s'embora, para jamais, o que ao menos se condizia mais correto, ou se arrependia, por uma vez, para casa.

No que num engano. Eu mesmo cumpria de trazer para ele, cada dia, um tanto de comida furtada: a ideia que senti, logo na primeira noite, quando o pessoal nosso experimentou de acender fogueiras em beirada do rio, enquanto que, no alumiado delas, se rezava e se chamava. Depois, no seguinte, apareci, com rapadura, broa de pão, cacho de bananas. Enxerguei nosso pai, no enfim de uma hora, tão custosa para sobrevir: só assim, ele no ao-longe, sentado no fundo da canoa, suspendida no liso do rio. Me viu, não remou para cá, não fez sinal. Mostrei o de comer, depositei num oco de pedra do barranco, a salvo de bicho mexer e a seco de chuva e orvalho. Isso, que fiz, e refiz, sempre, tempos a fora. Surpresa que mais tarde tive: que nossa mãe sabia desse meu encargo, só se encobrindo de não saber; ela mesma deixava, facilitado, sobra de coisas, para o meu conseguir. Nossa mãe muito não se demonstrava.

Mandou vir o tio nosso, irmão dela, para auxiliar na fazenda e nos negócios. Mandou vir o mestre, para nós, os meninos. Incumbiu ao padre que um dia se revestisse, em praia de margem, para esconjurar e clamar a nosso pai o 'dever de desistir da tristonha teima. De outra, por arranjo dela, para medo, vieram os dois soldados. Tudo o que não valeu de nada. Nosso pai passava ao largo, avistado ou diluso, cruzando na canoa, sem deixar ninguém se chegar à pega ou à fala. Mesmo quando foi, não faz muito, dos homens do jornal, que trouxeram a lancha e tencionavam tirar retrato dele, não venceram: nosso pai se desaparecia para a outra banda, aproava a canoa no brejão, de léguas, que há, por entre juncos e mato, e só ele conhecesse, a palmos, a escuridão, daquele. 
A gente teve de se acostumar com aquilo. Às penas, que, com aquilo, a gente mesmo nunca se acostumou, em si, na verdade. Tiro por mim, que, no que queria, e no que não queria, só com nosso pai me achava: assunto que jogava para trás meus pensamentos. $\mathrm{O}$ severo que era, de não se entender, de maneira nenhuma, como ele agüentava. De dia e de noite, com sol ou aguaceiros, calor, sereno, e nas friagens terríveis de meio-do-ano, sem arrumo, só com o chapéu velho na cabeça, por todas as semanas, e meses, e os anos - sem fazer conta do se-ir do viver. Não pojava em nenhuma das duas beiras, nem nas ilhas e croas do rio, não pisou mais em chão nem capim. Por certo, ao menos, que, para dormir seu tanto, ele fizesse amarração da canoa, em alguma ponta-de-ilha, no esconso. Mas não armava um foguinho em praia, nem dispunha de sua luz feita, nunca mais riscou um fósforo. O que consumia de comer, era só um quase; mesmo do que a gente depositava, no entre as raízes da gameleira, ou na lapinha de pedra do barranco, ele recolhia pouco, nem o bastável. Não adoecia? E a constante força dos braços, para ter tento na canoa, resistido, mesmo na demasia das enchentes, no subimento, aí quando no lanço da correnteza enorme do rio tudo rola o perigoso, aqueles corpos de bichos mortos e paus-de-árvore descendo — de espanto de esbarro. E nunca falou mais palavra, com pessoa alguma. Nós, também, não falávamos mais nele. Só se pensava. Não, de nosso pai não se podia ter esquecimento; e, se, por um pouco, a gente fazia que esquecia, era só para se despertar de novo, de repente, com a memória, no passo de outros sobressaltos.

Minha irmã se casou; nossa mãe não quis festa. A gente imaginava nele, quando se comia uma comida mais gostosa; assim como, no gasalhado da noite, no desamparo dessas noites de muita chuva, fria, forte, nosso pai só com a mão e uma cabaça para ir esvaziando a canoa da água do temporal. Às vezes, algum conhecido nosso achava que eu ia ficando mais parecido com nosso pai. Mas eu sabia que ele agora virara cabeludo, barbudo, de unhas grandes, mal e magro, ficado preto de sol e dos pêlos, com o aspecto de bicho, conforme quase nu, mesmo dispondo das peças de roupas que a gente de tempos em tempos fornecia.

Nem queria saber de nós; não tinha afeto? Mas, por afeto mesmo, de respeito, sempre que às vezes me louvavam, por causa de algum meu bom procedimento, eu falava: — "Foi pai que um dia me ensinou a fazer assim..."; o que não era o certo, exato; mas, que era mentira por verdade. Sendo que, se ele não se lembrava mais, nem queria saber da gente, por que, então, não subia ou descia o rio, para outras paragens, longe, no não-encontrável? Só ele soubesse. Mas minha irmã teve menino, ela mesma entestou que queria mostrar para ele o neto. Viemos, todos, no barranco, foi num dia bonito, minha irmã de vestido branco, que tinha sido o do casamento, ela erguia nos braços a criancinha, o marido dela segurou, para defender 
os dois, o guarda-sol. A gente chamou, esperou. Nosso pai não apareceu. Minha irmã chorou, nós todos aí choramos, abraçados.

Minha irmã se mudou, com o marido, para longe daqui. Meu irmão resolveu e se foi, para uma cidade. Os tempos mudavam, no devagar depressa dos tempos. Nossa mãe terminou indo também, de uma vez, residir com minha irmã, ela estava envelhecida. Eu fiquei aqui, de resto. Eu nunca podia querer me casar. Eu permaneci, com as bagagens da vida. Nosso pai carecia de mim, eu sei - na vagação, no rio no ermo - sem dar razão de seu feito. Seja que, quando eu quis mesmo saber, e firme indaguei, me diz-que-disseram: que constava que nosso pai, alguma vez, tivesse revelado a explicação, ao homem que para ele aprontara a canoa. Mas, agora, esse homem já tinha morrido, ninguém soubesse, fizesse recordação, de nada mais. Só as falsas conversas, sem senso, como por ocasião, no começo, na vinda das primeiras cheias do rio, com chuvas que não estiavam, todos temeram o fim-do-mundo, diziam: que nosso pai fosse o avisado que nem Noé, que, por tanto, a canoa ele tinha antecipado; pois agora me entrelembro. Meu pai, eu não podia malsinar. E apontavam já em mim uns primeiros cabelos brancos.

Sou homem de tristes palavras. De que era que eu tinha tanta, tanta culpa? Se o meu pai, sempre fazendo ausência: e o rio-rio-rio, o rio - pondo perpétuo. Eu sofria já o começo de velhice - esta vida era só o demoramento. Eu mesmo tinha achaques, ânsias, cá de baixo, cansaços, perrenguice de reumatismo. E ele? Por quê? Devia de padecer demais. De tão idoso, não ia, mais dia menos dia, fraquejar do vigor, deixar que a canoa emborcasse, ou que bubuiasse sem pulso, na levada do rio, para se despenhar horas abaixo, em tororoma e no tombo da cachoeira, brava, com o fervimento e morte. Apertava o coração. Ele estava lá, sem a minha tranquilidade. Sou o culpado do que nem sei, de dor em aberto, no meu foro. Soubesse - se as coisas fossem outras. E fui tomando ideia.

Sem fazer véspera. Sou doido? Não. Na nossa casa, a palavra doido não se falava, nunca mais se falou, os anos todos, não se condenava ninguém de doido. Ninguém é doido. Ou, então, todos. Só fiz, que fui lá. Com um lenço, para o aceno ser mais. Eu estava muito no meu sentido. Esperei. Ao por fim, ele apareceu, aí e lá, o vulto. Estava ali, sentado à popa. Estava ali, de grito. Chamei, umas quantas vezes. E falei, o que me urgia, jurado e declarado, tive que reforçar a voz: - "Pai, o senhor está velho, já fez o seu tanto... Agora, o senhor vem, não carece mais... O senhor vem, e eu, agora mesmo, quando que seja, a ambas vontades, eu tomo o seu lugar, do senhor, na canoa!..." E, assim dizendo, meu coração bateu no compasso do mais certo. 
Ele me escutou. Ficou em pé. Manejou remo n'água, proava para cá, concordado. E eu tremi, profundo, de repente: porque, antes, ele tinha levantado o braço e feito um saudar de gesto - o primeiro, depois de tamanhos anos decorridos! E eu não podia... Por pavor, arrepiados os cabelos, corri, fugi, me tirei de lá, num procedimento desatinado. Porquanto que ele me pareceu vir: da parte de além. E estou pedindo, pedindo, pedindo um perdão.

Sofri o grave frio dos medos, adoeci. Sei que ninguém soube mais dele. Sou homem, depois desse falimento? Sou o que não foi, o que vai ficar calado. Sei que agora é tarde, e temo abreviar com a vida, nos rasos do mundo. Mas, então, ao menos, que, no artigo da morte, peguem em mim, e me depositem também numa canoinha de nada, nessa água que não pára, de longas beiras: e, eu, rio abaixo, rio a fora, rio a dentro - o rio. 


\section{II - A terceira margem do rio}

(Letra: Caetano Veloso, Melodia: Milton Nascimento)

Oco de pau que diz:

Eu sou madeira, beira

Boa, dá vau, triztriz

Risca certeira

Meio a meio o rio ri

Silencioso, sério

Nosso pai não diz, diz:

Risca terceira

Água da palavra

Água calada, pura

Água da palavra

Água de rosa dura

Proa da palavra

Duro silêncio, nosso pai

Margem da palavra

Entre as escuras duas

Margens da palavra

Clareira, luz madura

Rosa da palavra

Puro silêncio, nosso pai

Meio a meio o rio ri

Por entre as árvores da vida

$\mathrm{O}$ rio riu, ri

Por sob a risca da canoa

$\mathrm{O}$ rio viu, vi

O que ninguém jamais olvida

Ouvi, ouvi, ouvi

A voz das águas

Asa da palavra

Asa parada agora

Casa da palavra 
Onde o silêncio mora

Brasa da palavra

A hora clara, nosso pai

Hora da palavra

Quando não se diz nada

Fora da palavra

Quando mais dentro aflora

Tora da palavra

Rio, pau enorme, nosso pai 


\section{III - Palavras a um general}

(poema de Bertolt Brecht)

General, teu tanque é um carro forte.

Ele derruba uma floresta

e esmaga cem homens.

Tem, porém um defeito:

Precisa de um motorista.

General, teu bombardeiro é poderoso.

Voa mais depressa que a tempestade,

Carrega mais que um elefante.

Tem, porém um defeito:

Precisa de um piloto.

General, o homem é muito útil

Sabe voar, sabe matar.

Tem, porém um defeito:

ele sabe pensar. 